Wiriyasermkul, et al.

\title{
1 D-Serine, an emerging biomarker of kidney diseases, is a hidden substrate of
}

\section{2 sodium-coupled monocarboxylate transporters}

3

4 Pattama Wiriyasermkul ${ }^{1}$, Satomi Moriyama ${ }^{1}$, Yoko Tanaka ${ }^{1}$, Pornparn Kongpracha ${ }^{1}$, Nodoka

$5 \quad$ Nakamae $^{1}$, Masataka Suzuki², Tomonori Kimura ${ }^{3,4}$, Masashi Mita ${ }^{5}$, Jumpei Sasabe ${ }^{2}$, Shushi

6 Nagamori ${ }^{1, \#}$

7

$8 \quad{ }^{1}$ Department of Collaborative Research for Biomolecular Dynamics, Nara Medical

9 University, Nara, Japan

10 2Department of Pharmacology, Keio University School of Medicine, Tokyo, Japan

$11{ }^{3}$ KAGAMI Project, ${ }^{4}$ Reverse Translational Research Project, Center for Rare Disease

12 Research, National Institutes of Biomedical Innovation, Health and Nutrition (NIBIOHN).

13 Osaka, Japan

$14 \quad{ }^{5}$ KAGAMI Inc., Osaka, Japan

15

16 \# Corresponding contact information: snagamori@nagamori-lab.jp

17

21 Keywords: transporter, proteome, ischemia-reperfusion injury (IRI), acute kidney injury

22 (AKI), chronic kidney diseases (CKD), membrane 
Wiriyasermkul, et al.

\section{Abstract}

24 Delay in diagnosis of renal injury has profound impacts on morbidity and mortality.

25 Damage of proximal tubules by the injury impairs not only individual membrane transport

26 proteins but also coordinated transport systems. In this study, we analyzed the proteome of

27 apical membranes of proximal tubular epithelium from the mouse kidney with early ischemia-

28 reperfusion injury (IRI), a well-known acute kidney injury (AKI) model. The proteome showed

29 drastic elevations of the injury-responsive proteins and depressions of abundant transporters,

30 leading to the prediction of biomarkers for early IRI. As the benchmark of our in-depth analysis

31 from the proteome, we characterized transporters for D-serine, a promising renal diseases'

32 biomarker. Using cell-based and cell-free methods, we identified sodium-coupled

33 monocarboxylate transporters (SMCTs) as the D-serine transporters. This finding enlightens

34 the role of non-canonical substrate transport and clarifies the D-serine transport systems in the

35 kidney. Our approaches can be applied for investigation of other membrane transport systems.

\section{$40 \quad$ Impact statement}

41 Proteomics and biochemical analysis reveal D-serine as a non-canonical substrate of sodium-

42 coupled monocarboxylate transporter SMCTs 
Wiriyasermkul, et al.

43

\section{Introduction}

The renal system, where membrane transport proteins are the most diverse and abundant, plays crucial roles in body homeostasis, thereby often being the most impacted from critical illness and vulnerability to the subtle changes in molecular substances. Acute kidney injury (AKI) and chronic kidney diseases (CKD), which are common diseases worldwide, cause severe health problems but encounter the limitations on standard diagnosis and classification (Zhang and Parikh, 2019). AKI and CKD are considered as interconnected syndromes. Although AKI happens suddenly and is reversible, the extension of the injury and incomplete repairment of renal tubular cells consecutively lead to CKD progression (Devarajan and Jefferies, 2016). Hence, the gold-standard diagnosis at the early stages of AKI is an important key factor needed in order to maximize the therapeutic success and minimize CKD development. Conventional markers for AKI diagnosis include measuring serum creatinine levels and estimated Glomerular filtration rate (eGFR). Still, both methods are limited in their specificity, lack of standardized quantification, variation in individuals, and limited usage in patients with comorbidities (Ostermann and Joannidis, 2016). Lately, systemic analysis using innovative technologies, such as Integrative Omics and Next-Generation Sequencing, have opened new possibilities for detecting biomarkers of AKI and CKD. Yet, the new biomarkers have restrictions on their application and efficacy due to the specificity and the unclear characterization of the underlying molecular mechanism (Eddy et al., 2020; Kirita et al., 2020; Liu et al., 2020; Marx et al., 2018; Thongboonkerd, 2020; Zhang and Parikh, 2019).

Proximal tubule, the main part for reabsorption and secretion of metabolites and organic compounds in the kidney, is the primary target of AKI and CKD progression (Chevalier, 2016). Thus, apical (luminal) membrane proteins from proximal tubular epithelium would represent significant pathological membrane transport proteins that are the underlying mechanisms of metabolite biomarkers for AKI and CKD. D-Serine, a dextro isomer of serine, is discovered as 
one of the promising biomarkers for AKI and CKD detections using the 2D-HPLC method (Hesaka et al., 2019; Kimura et al., 2020, 2016; Sasabe et al., 2014; Sasabe and Suzuki, 2018). In the normal condition, D-serine is in high ratio to urine but low in plasma. Contrarily, the plasma D-serine is elevated in patients and animal models with CKD and AKI, while the luminal D-serine is decreased. The amount of D-serine is strongly associated with kidney function and progression of these diseases. Transport of D-serine takes place at the proximal tubule (Kragh-Hansen and Sheikh, 1984; Sasabe and Suzuki, 2018; Shimomura et al., 1988; Silbernagl et al., 1999). However, such a corresponding transporter in both physiological and pathological conditions has not been clearly explained. Until now, three amino acid transporters, SLC1A4/ASCT1, SLC1A5/ASCT2, and SLC7A10/Asc-1 are recognized to mediate D-serine transport in the brain (Foster et al., 2016;

82 Rosenberg et al., 2013). Despite the role and transport system of D-serine in brain, little is known about D-serine in peripheral tissues. Mammals acquire D-serine by biosynthesis via serine racemase function and absorption from dietary and gut microbiota via intestinal transport system(s) (Sasabe et al., 2016; Sasabe and Suzuki, 2018). The D-serine homeostasis in the plasma is controlled by luminal-membrane transporters and DAAO activities in the intestine and kidney. In the kidney, D-serine from blood, which passed through the renal glomeruli, is reabsorbed at proximal tubules. Subsequently, intracellular D-serine is degraded by DAAO, which is located in the proximal tubular cells, thereby maintaining the plasma D-serine at low

90 levels (Sasabe et al., 2014). It is suggested by the serum and urinary D/L serine profile of the

91 CKD patients and AKI animal models that the renal D-serine transport properties in 
92 physiological conditions and in pathological conditions are different and have distinct

93 stereoselectivity (Sasabe and Suzuki, 2018).

94 The reabsorption and excretion of a substance in the kidney is co-operated by multiple

95 plasma membrane transport proteins (Chu et al., 2016; Ghezzi et al., 2018; Kandasamy et al.,

96 2018). Malfunction of a single type of membrane transport protein causes a fluctuation in the

97 chemical gradient of the substrates and affects other transport systems that also transport the

98 same substance. Therefore, it is necessary to consider that renal dysfunction is caused by not

99 only the breaking down of several transport systems themselves but also the disruption of the

100 coordination between each transport system. Here, we applied proteomics of apical membranes

101 from renal proximal tubules of the mice with ischemia-reperfusion injury (IRI), a well-known model for AKI and AKI-CKD transition (Fu et al., 2018; Sasabe et al., 2014), to reveal the membrane transport proteins that are responsible for the transport of AKI metabolite

104 biomarkers, especially the D-serine transport system as a paradigm. By further screening and

105 kinetic analysis, we identified two D-serine transport systems at the apical membranes of

106 proximal tubules - sodium-coupled monocarboxylate transporters (SMCTs) and neutral amino

107 acid transporter ASCT2, which explain the mechanism of chiral selection and elevation of Dserine transport in $\mathrm{AKI}$ and $\mathrm{CKD}$. 


\section{Results}

110 Membrane proteome of renal proximal tubules of the IRI model

To understand the molecular pathophysiology of AKI, we characterized proteomes of

112 renal brush border membrane vesicles (BBMVs), the membrane fraction representing the

113 apical membranes of proximal tubular epithelium, from the IRI mouse model. We analyzed the

114 samples from 4 hours and 8 hours after ischemia-reperfusion (4h IRI and $8 \mathrm{~h}$ IRI) because these

115 time points are considered as early stages of AKI, where serum creatinine levels are slightly

116 increased, and urine KIM-1 remains unchanged (Sasabe et al., 2014). The proteome of IRI

117 samples was calculated as ratios of the negative control group (sham), yielding two groups of

118 comparative proteome data: 4h IRI/sham (4h) and 8h IRI/sham (8h). In total, 4,426 proteins

119 were identified in which 1,186 proteins were categorized as plasma membrane proteins and

120 extracellular matrix proteins (Table supplement 1, Figure supplement 1A). Among them, 1,110

121 proteins were predicted to possess more than one transmembrane domain (Table supplement

122 1). We observed a great increase of two well-known early AKI biomarkers - CCN1 (CYR61:

123 matrix-associated heparin-binding protein; the ratio of $4 \mathrm{~h} / \mathrm{sham}=41.4$; the ratio of $8 \mathrm{~h} / \mathrm{sham}=$

124 29.9) and NGAL (LCN2: Neutrophil gelatinase-associated lipocalin; the ratio of 4h/sham =

1251.8 ; the ratio of $8 \mathrm{~h} / \mathrm{sham}=9.5$ ), which confirmed the reliability of our proteomics on the IRI

126 model for early AKI (Table supplement 1) (Marx et al., 2018). To characterize pathological

127 changes in IRI, we selected 318 proteins which passed a cut-off value of 1.5 fold change $\left(\log _{2}\right.$

128 fold of IRI/sham $=0.58$ : both increased and decreased $)$ with $p$-value $\leq 0.05\left(-\log _{10} p\right.$-value $\geq$

129 1.3) and further analyzed the biological functions and toxicity functions by using IPA. Top-10

130 toxicity functions verified the damages of the kidney due to the injury and inflammation

131 (Figure supplement 1B). Hierarchical heatmaps of the organ pathologies prognosticate various

132 defects in the kidney which include tubule dilation, nephritis, kidney injury and damage, and 
133 renal failure (Figure supplement 1C). Besides the renal pathologies, IPA also indicated the

134 injury and damage in the liver and heart as several corresponding proteins are shared among

135 the organs (Figure supplement 1C).

136 Analysis of biological functions showed the proteome was highly involved in cellular 137 compromise, cell survival, molecular transport, and system development (Figure 1A-B). The 138 hierarchical heatmap exhibited that most of the biological functions are increased (with a 139 decrease of cell death), which indicated the mechanisms related to the injury responses rather 140 than the pathophysiological functions (Figure 1C). We categorized the injury responses into 141 three groups: rapid responses, prolonged responses, and slow responses. The first group, rapid 142 responses, shows biological functions are highly increased at $4 \mathrm{~h}$ IRI but gradually reduced at $1438 \mathrm{~h}$ IRI. The responses related to pro-inflammation and innate immunity, which include the 144 complementary system, free radical scavenging, metal ion elevation, lipid synthesis, lipid 145 transport, and lipid metabolism (Figure 1C). The second group is involved in the biological 146 functions that are rapidly increased at $4 \mathrm{~h}$ IRI and maintained to $8 \mathrm{~h}$ IRI, named prolonged 147 responses. Cell viability and homeostasis, cell-cell interaction, epithelial cell movement, and 148 vascularization are the biological functions in the prolonged responses in order to sustain an 149 effective immune response (Figure 1C). The third group called slow responses are those 150 increased functions at $8 \mathrm{~h}$ IRI, including the adaptive immunity-leukocyte/lymphocyte 151 migration and phagocytosis, immune cell and connective tissue adhesion, and endothelial 152 tissue development (Figure 1C). At 8h, we observed the significant increase of cellular 153 compromise and tissue development, implying the initiation of the repairment systems (Figure 154 1A-B). Analysis of diseases relevant to biological functions showed the remarkable elevation 155 of the inflammatory response at both $4 \mathrm{~h}$ and $8 \mathrm{~h}$ IRI, confirming the significant contribution of 156 the rapid, prolonged, and slow responses (Figure 1D). Although the immune-related responses 157 and tissue repairment were progressive, we still observed the tissue abnormality, tissue damage, 
and inflammation (Figure 1D). From the results, we concluded the biological functions in early AKI (both $4 \mathrm{~h}$ and $8 \mathrm{~h} \mathrm{IRI)} \mathrm{as} \mathrm{follows:} \mathrm{1)} \mathrm{the} \mathrm{immune} \mathrm{system} \mathrm{rapidly} \mathrm{and} \mathrm{extensively} \mathrm{responded}$ to the injury since $4 \mathrm{~h}$ IRI, 2) the processes of tissue development and repair were initiated at

$1618 \mathrm{~h} \mathrm{IRI}$, and 3) the pathological features of the injured kidney were prolonged observed since 1624 4h IRI.

Next, we predicted a series of protein biomarkers to detect early stages of the kidney injury and found 34 proteins significant altered at both $4 \mathrm{~h}$ and $8 \mathrm{~h}$ IRI (Figure 1E). Table 1 summarizes the physiological function and previous applications of these proteins. The protein biomarkers previously proposed for AKI, CKD, and related kidney diseases are CCN1/CYR61,

PAFAH1B2, OCLN, PCOLCE, GPC4, and CMKLR1 are molecules involved in cell structure, cell-cell interaction, and tissue development. LDLR, ESYT1, and APOA2 are correlated with lipid transport and homeostasis. The last group of candidates which were mostly found decreased in IRI are membrane transport proteins: SLC15A2/PEPT2, SLC19A3/THTR2, SLC2A5/GLUT5, PIEZO1, and KCNAB2.

We analyzed the biological networks and found two top-scoring networks were related to the rapid responses (Figure 2A-B), while another network related to the prolonged responses prolonged responses (Figure supplement 2). Although we did not examine the total proteome, we could predict the master regulators of the networks from our membrane proteome. In the 
Wiriyasermkul, et al.

183

184

185

2A-B). HDL complex was found to be a central regulator for the prolonged responses and Akt was predicted to be involved (Figure 2C). BCL2, ANXA1, and integrin complex are important regulators for tissue development and repair in the slow responses (Figure supplement 2).

\section{Alterations of membrane transport proteins in the kidney of the IRI model}

To unveil the renal pathophysiological defect behind the injury responses, we analyzed the whole proteome without any cutoff to recognize slight changes of the silent molecules. The analysis depicted a high scoring of pathological functions related to kidney diseases and the circulatory system (Figure supplement 3). These data intimate that the proximal tubular membrane proteins involved in IRI pathological mechanisms altered less in the amounts than the injury-responsive proteins but were abundant in the membrane proteome. Among these membrane proteins, membrane transport proteins were one of the leading groups. Because the substrates of these membrane transport proteins are well-used metabolite biomarkers for AKI, $\mathrm{CKD}$, and other diseases, we further investigated membrane transport proteins to unveil the pathogenic mechanisms. We selected the 319 membrane transport proteins comprising ATPbinding cassette (ABC) transporters, solute-carriers (SLCs), ATPase pumps, and channels to analyze their biological functions by IPA without any cutoff. The analysis unveiled two transport groups based on the types of substrates; 1) ions and 2) organic compounds (Figure 3A). The ions are composed of inorganic ions (Figure 3A: lower left) and charged organic compounds (Figure 3A: right). The organic compounds comprise both charged and uncharged compounds (Figure 3A: right). IPA analysis showed that the transport of ions remained unchanged at $4 \mathrm{~h}$ IRI and slightly increased at $8 \mathrm{~h}$ IRI. The sum of ions which indicated less change was actually made up from the combination of anions and cations in which both of them altered in some degrees at the opposite direction (Figure 3A: left). In particular, sum of ions which showed small alteration was caused by the dynamic alteration of various inorganic 
208 the cells are suggested to have neural $\mathrm{pH}$ at $4 \mathrm{~h}$ IRI and slight $\mathrm{pH}$ change at $8 \mathrm{~h}$. We suggest that

209 the injured cells attempted to preserve cellular $\mathrm{pH}$ and ion homeostasis, which was a foundation

210 for the function of organic compound transporters and substantial protein functions. In contrast

211 to the ion transport group, the protein group that transports organic compounds was strongly

212 decreased at $4 \mathrm{~h}$ and gradually recovered at $8 \mathrm{~h}$ (Figure 3A: right). Most proteins in this group

213 were found to be decreased, indicating that their defect was from the damaged brush border

214 membranes and delayed in recovery (Figure 3B). The levels of less alteration in membrane

215 transport proteins also imply the low expression levels compared to the proteins in the injury

216 responses.

217 Screening of candidate molecules for D-serine transporters

Membrane transport proteins derived from our proteome represent a good collection

219 for identification of transport systems for the anticipated metabolite biomarkers of renal injury

220 with unknown transporter(s) or novel metabolite biomarkers. Since D-serine has been proposed

as an effective biomarker for AKI and CKD yet unknown transport mechanism, we aimed to

characterize the D-serine transport system in the kidney. From the membrane proteome, we detected the increases of ASCT2 at both $4 \mathrm{~h}$ and $8 \mathrm{~h}$ IRI (Figure 4A, Table 2). Using HAP1 cells carrying CRISPR/CAS-mediated ASCT2 knockout, we examined D-serine uptake and confirmed that ASCT2 is a D-serine transporter (Figure supplement 4A). ASCT2 is located at the apical membranes of all proximal tubular segments and transports serine with high affinity

227 ( $\mathrm{K}_{\mathrm{m}}$ of $167 \mu \mathrm{M}$ for D-serine in oocyte system) but weak stereoselectivity (Foster et al., 2016).

228 However, the previous studies demonstrated D-serine transport systems in S1-S2 and S3 229 segments are different and their kinetics are in mM range (Kragh-Hansen and Sheikh, 1984;

230 Silbernagl et al., 1999). Silbernagl et al. also suggested ASCT2 is not (or not only) a D-serine 
transporter at pars recta (Silbernagl et al., 1999). Notably, the serum and urinary D/L serine

232 profile from CKD and AKI samples indicated the stereoselective transporter(s) (Sasabe and

233 Suzuki, 2018). We thus postulated the existence of (an)other D-serine transporter(s). To screen

234 and identify D-serine transporters, we choose ASCT2 as a pivotal molecule to make the cut-off

235 line in our membrane proteomics data. We selected membrane transport proteins that altered more than ASCT2 at both $4 \mathrm{~h}$ and $8 \mathrm{~h}$ IRI (Figure 4A). To further focus on the reabsorption system at the lumen, we omitted transporters that are reported to be in basolateral membranes and organelles. Membrane transport proteins that recognize only inorganic ions were excluded.

SLC36A1/PAT1 and SLC6A18/B ${ }^{0}$ AT3, known small amino acid transporters, were included,

240 although they only passed the cut-off value at one of the time points, either $4 \mathrm{~h}$ or $8 \mathrm{~h}$.

241 SLC5A12/SMCT2 was also included in the list with less significant alteration because SMCT1,

has a comparable role with SMCT1 in monocarboxylate reabsorption at apical membranes, but they localize at different segments of proximal tubules. Finally, ten candidates of D-serine transporters were listed (Table 2).

HEK293 cell line was used for the development of the screening method of D-serine acid transporters from membrane proteome of HEK293 cells (Table supplement 2). Then, we examined which transporters are responsible for D-serine transport in the cells. From the results, D-serine transport in HEK293 cells required $\mathrm{Na}^{+}$and was inhibited by ASCT2 substrates (L-

251 Ser, L-Thr, and L-Met) (Figure supplement 4B-C). Inhibition by Ben-Cys and GPNA in HEK293 cells showed a similar pattern to that of ASCT2-expressed cells (Bröer et al., 2016), but MeAIB (system A inhibitor) had no effect (Figure supplement 4C). Using siRNA to 254 knockdown ASCT2, we verified that ASCT2 is a main D-serine transporter in HEK293 cells 255 (Figure 4B-C). A previous study showed that treatment with D-serine in a human proximal 
tubular cell line impaired the growth (Okada et al., 2017). We found that this growth defect $\mathrm{mM}$ (Figure supplement 4D). In the ASCT2-knockdown cells, the growth inhibition by Dserine was attenuated (Figure 4D), indicating the D-serine taken up by ASCT2 contributes to the D-serine-suppressed cell growth.

(near the $\mathrm{IC}_{50}$ concentration) and $25 \mathrm{mM}$ (high concentration), Asc-1 transfected cells (positive control) showed significantly lower growth than the Mock cells, confirming this assay is

SMCTs transport D-serine into the cells. Accordingly, SMCT1 and SMCT2 are primarily

270 selected for further analysis (Figure supplement 5).

\section{Characterization of D-serine transport in SMCTs.}

SMCTs are sodium-dependent monocarboxylate symporters. Their canonical substrates are short-chain fatty acids and monocarboxylates such as lactate, propionate, and

SMCT1) and SMCT2 (FlpInTR-SMCT2). Expression of SMCTs in FlpInTR-SMCT1 and 
$\left[{ }^{14} \mathrm{C}\right]$ nicotinate uptake (Figure supplement $6 \mathrm{~B}-\mathrm{C}$ ). Ibuprofen, an SMCT inhibitor, was used to verify the growth inhibition effect by SMCTs. Unlike Mock in which ibuprofen has no effect, the growth inhibition by D-serine treatment were gradually attenuated by ibuprofen in both FlpInTR-SMCT1 and FlpInTR-SMCT2 cells (Figure 5C). and SMCT2 cells showed an increase of $\mathrm{D}-\left[{ }^{3} \mathrm{H}\right]$ serine transport compared to Mock with or inhibitors) (Figure 6B) (Gopal et al., 2007; Itagaki et al., 2006). D-Serine and nicotinate also inhibited D- $\left[{ }^{3} \mathrm{H}\right]$ serine uptake in the SMCT1 cells but much less effective in the SMCT2 cells suggesting the low affinity of D-serine in SMCT2 than SMCT1 (Figure 6B).

\section{Transport properties and kinetics of D-serine in SMCT1}

Kinetics of D- $\left[{ }^{3} \mathrm{H}\right]$ serine transport in SMCT1 was measured in FlpInTR-SMCT1 cells

in the presence of ASCT2 knockdown. SMCT1 transported D- $\left[{ }^{3} \mathrm{H}\right]$ serine in a concentrationdependent manner, and the curve fitted to Michaelis-Menten kinetics with the apparent $\mathrm{K}_{\mathrm{m}}$ of $5.0 \mathrm{mM}$ (Figure 6C, supplement 6E).

Because there were the high backgrounds of D-serine transport in cells, even in the ASCT2-knockdown condition, we assumed that endogenous transporters, including uncharacterized molecules, and metabolites impede the examination of the SMCT1 properties precisely. We then characterized the D-serine transport properties of the purified SMCT1 in SMCT1-reconstituted proteoliposomes. Liposomes are spherical-shaped vesicle made from

301 lipid mixtures to mimic the membrane lipid bilayer. The proteoliposomes are the liposomes 

was confirmed by Western blot using anti-FLAG antibody (Figure supplement 7A). SDS-

307 PAGE showed the successful incorporation of the purified SMCT1 in the proteoliposomes

308 (SMCT1-PL) (Figure 7A). We measured the uptake of L- and D-[ $\left.{ }^{3} \mathrm{H}\right]$ serine in SMCT1-PL. In the presence of external $\mathrm{Na}^{+}, \mathrm{SMCT} 1$ transported both $\mathrm{L}-$ and $\mathrm{D}_{-}\left[{ }^{3} \mathrm{H}\right]$ serine as well as the canonical substrates $\left(\left[{ }^{3} \mathrm{H}\right]\right.$ lactate and $\left[{ }^{3} \mathrm{H}\right]$ propionate) (Figure $7 \mathrm{~B}$, supplement $7 \mathrm{~B}$ ). The transport was dramatically inhibited by ibuprofen, confirming the function of SMCT1 (Figure

$3127 \mathrm{~B}$, supplement 7B). The time courses of $\mathrm{D}-\left[{ }^{3} \mathrm{H}\right]$ serine uptake were measured in both $\mathrm{Na}^{+}$and

$313 \mathrm{Na}^{+}$-free buffers. The results showed that SMCT1 transported $\mathrm{D}-\left[{ }^{3} \mathrm{H}\right]$ serine in $\mathrm{Na}^{+}$-dependent condition (Figure 7C and supplement 7C). The uptake value in $\mathrm{Na}^{+}$-free buffer is a result of non-specific accumulation in liposomes/proteoliposomes, which is slightly linear upon the incubation time (Figure supplement 7C). SMCT1 recognized both L- and D-serine over other

317 small amino acids (L- and D-alanine), acidic amino acids (L- and D-glutamate), or large neutral

318 amino acids (L- and D-tyrosine) (Figure 7D). Uptake of L- and D-serine was approximately 30\%

319 and $60 \%$ of lactate, respectively (Figure 7D). These results indicated that SMCT1 transported serine with lower affinity than its canonical substrates, and the recognition is more stereoselective to D- than L- isomer.

\section{D-Serine reabsorption in renal proximal tubular cells}

To investigate the function of transporters at the apical membranes of proximal tubules under controlled conditions of chemical gradients, we used mouse brush border membrane vesicles (BBMVs), which enriched the apical membrane transporters. D-Serine transport in mouse BBMVs was examined in different conditions to distinguish the contribution of ASCT2 
328 efflux of L-glutamine while SMCTs are symporters (Ganapathy et al., 2008; Scalise et al.,

329 2018), we performed D-serine transport assay in BBMVs with or without L-glutamine 330 preloading. In L-glutamine-preloaded BBMVs, transport of $\mathrm{D}-\left[{ }^{3} \mathrm{H}\right]$ serine arose quickly and 331 reached the saturated point at $20 \mathrm{sec}$ (Figure 8A, supplement $8 \mathrm{~A}$ ). The uptake was ibuprofen332 insensitive at $10-30 \mathrm{sec}$ and became partially ibuprofen-sensitive at $1 \mathrm{~min}$ (Figure $8 \mathrm{~A}$ ). In 333 contrast, transport of D- $\left[{ }^{3} \mathrm{H}\right]$ serine in BBMVs without the preloading increased slowly (Figure 334 8B). D- $\left[{ }^{3} \mathrm{H}\right]$ Serine transport was initiated after $30 \mathrm{sec}$ and reached the optimum at 2 min (Figure $8 \mathrm{~B}$, supplement $8 \mathrm{~B})$. Notably, the transport was largely inhibited by ibuprofen which is a SMCT inhibitor, but not by L-threonine which is an ASCT2 substrate (Figure 8B-C). These results suggested that, in the L-glutamine preloading condition, positive $\mathrm{D}-\left[{ }^{3} \mathrm{H}\right]$ serine transport at 10 - $30 \mathrm{sec}$ was derived from the antiport mode of Asct2, which occurred rapidly. Meanwhile,

SMCTs function started slowly at $60 \mathrm{sec}$ as seen in the non-preloading condition. As a result, $\mathrm{D}-\left[{ }^{3} \mathrm{H}\right]$ serine transport at $1 \mathrm{~min}$ in L-glutamine preloading condition was from the combinational functions of both ASCT2 and SMCTs (Figure 8A). in all segments and enriched in S1 of proximal tubules (Gopal et al., 2007; Kirita et al., 2020).

344 Although ASCT2 has been intensively studied in cells or other organs, the localization and 345 function in the kidney have not been well characterized. We generated affinity-purified Asct2 346 antibodies to recognize both N-terminus (NT) and C-terminus (CT) of Asct2 (Figure 347 supplement 8C) and detected Asct2 in mouse kidney. Asct2 was co-immunostained with both 348 Sglt2 (Slc5a2; sodium/glucose cotransporter 2) and Agt1 (slc7a13, aspartate/glutamate transporter 1), which are apical membrane markers for $\mathrm{S} 1+\mathrm{S} 2$ and $\mathrm{S} 3$ segments, respectively

350 (Figure 8D-E) (Ghezzi et al., 2018; Nagamori et al., 2016a). In contrast, Asct2 did not co351 localize with $\mathrm{Na}^{+} / \mathrm{K}^{+}$-ATPase, which is a basolateral membrane marker (Figure $8 \mathrm{~F}$ ). The results 352 demonstrated that Asct2 is localized at the apical side in all segments of proximal tubules. 
Wiriyasermkul, et al.

353

354

355

356

357

358

359

360

361

362

363

364

365

366

367

368

369

370

371

372

373

\section{Discussion}

Our membrane proteome revealed two major groups of the proteins classified by biological functions. The first group is involved in injury/inflammatory responses and tissue repairs. Most proteins in this group exhibited high degrees of elevation and various subcellular localization. Many of them are often found in the omics research and the list of protein biomarkers in kidney diseases (Eddy et al., 2020; Marx et al., 2018; Thongboonkerd, 2020; Zhang and Parikh, 2019). On the other hand, the second group is rather specific to the pathogenic proteins in IRI. The dominant protein types in the second group are membrane transport proteins. Many of the membrane transport proteins showed low degrees of alteration in IRI, adding difficulty to their identification from the whole-cell/tissue proteome and transcriptome. In this study, we succeeded in identifying multiple membrane proteins, in particular transporters located at the apical membranes of proximal tubules. The membrane proteome allows us to examine how transporters play roles in the normal condition or in the injured condition.

Based on the proteome data, we utilized the intensive biochemical assays including "in vitro" cultured cells, "cell-free" proteoliposomes, and "ex vivo" BBMV methods to identify SMCT1, SMCT2, and ASCT2 as D-serine transporters at the apical membranes of renal proximal tubules. SMCT1 has preference on D-serine over L-serine and other amino acids (Figure 7D). The apparent $\mathrm{K}_{\mathrm{m}}$ of $\mathrm{D}$-serine transport in SMCT1 is $5.0 \mathrm{mM}$ which is considered to be low affinity (Figure 6C). We attempted to examine the kinetics of D-serine transport in SMCT2. However, the uptake values at high D-serine concentration were low and concealed by the high background, indicating a lower affinity of SMCT2 than that of SMCT1. These results are in agreement with the physiological properties of SMCT1 and SMCT2 as the lowaffinity transporters for their canonical substrates although the affinity of SMCT1 is higher than that of SMCT2 (Ganapathy et al., 2008). We conclude that SMCT1 and SMCT2 transport 
378 D-serine with low affinity and high stereoselectivity toward the D- isomer. On the contrary,

379 ASCT2 transports D-serine with high affinity ( $\mu \mathrm{M}$ range) although approximately 8 folds less

380 than L-serine (Foster et al., 2016).

It is surprising, but reasonable once we found that SMCTs transport D-serine. Several

studies reported the transport of non-canonical substrates by membrane transport proteins

especially the recognition between amino acids, carboxylates and amines among SLC

transporters (de Carvalho and Quick, 2011; Matsuo et al., 2008; Metzner et al., 2005;

Schweikhard and Ziegler, 2012; Wei et al., 2016). D-Serine structure consists of a hydroxypropionic acid with an amino group at the $\alpha$-carbon. It is likely that the canonical substrates.

Previous studies indicated D-serine transport takes place at the proximal tubules by the of each system were not clearly distinguished, both systems exhibited the characteristics of $\mathrm{Na}^{+}$ dependency, electrogenicity, low affinity ( $\mathrm{mM}$ range), and partial stereoselectivity (KraghHansen and Sheikh, 1984; Shimomura et al., 1988; Silbernagl et al., 1999). These D-serine transport properties suit well to SMCTs and convince the contribution of SMCTs to renal Dserine transport in addition to ASCT2. It was reported that a fair amount of D-serine from gut microbiota mitigates AKI (Nakade et al., 2018). However, a high dose of D-serine administration induces nephrotoxicity by targeting proximal tubules and confining at the S3 segment (Hasegawa et al., 2019; Morehead et al., 1945; Silbernagl et al., 1999). It is most likely that the D-serine-induced proximal tubular damage is (partly) due to the absorption of D-serine 

transports D-serine with high affinity in vitro (Foster et al., 2016), the amount of ASCT2 in the

406 kidney is much lower than those of SMCTs (Table 2: abundance in Sham) indicating the low capacity of D-serine reabsorption. In contrast, the high abundance and low affinity of SMCTs substrates of SMCTs exist, the amount of reabsorbed D-serine via SMCTs would be relatively

411 low because the luminal D-serine amount is low and D-serine competes with SMCTs' canonical 412 substrates. Possibly, SMCTs take up D-serine by chance, and the reabsorbed D-serine may not

413 be important for carbon-source supplement or particular renal activities as the reabsorbed D-

414 serine is also degraded by DAAO. Despite the inconspicuous merit of reabsorbed D-serine,

415 functional activity of SMCTs to transport D-serine is significant in order to preserve the low-

416 level of serum D-serine.

417 De novo cells, stem cells, and cancer cells share common characteristics of high 418 proliferative rate and metabolic demands. In the IRI condition where the damaged proximal 419 tubules attempt to recover their function by tissue development and repair, functions of high420 affinity transporters would denote great benefit to supply enormous nutrients in a short time. 421 In these regards, ASCT2 is a good candidate for the cellular response mechanism. ASCT2 is 422 found in placenta for fetus development and highly expressed in cancer cells and stem cells 423 (Formisano and Van Winkle, 2016; Kandasamy et al., 2018; Scalise et al., 2018). ASCT2 plays 424 a key role in regulation of mammalian target of rapamycin (mTOR) signaling pathway and 425 glutamine-mediated metabolism (Kandasamy et al., 2018; Scalise et al., 2018). Our proteome 

upregulation is a result of a proliferative pathway for cell growth and repair. (Figure 8G). In physiological conditions, SMCT1 and SMCT2 mainly contribute to D-serine transport with low affinity. Intracellular D-serine is then catalyzed by DAAO in the proximal tubule. As a consequence, the meager amount of D-serine is detected in serum (Sasabe et al., model (Table 2, Figure supplement 5). The increase and high affinity of ASCT2 bring about larger D-serine reabsorption. Thus, luminal D-serine is decreased in the pathophysiological conditions (Figure 8G). Recently, SMCT2 was reported as a protein indicator for kidney repair from the injury. Prolonged SMCT2 down-expression indicated the failed repair of proximal tubular cells in IRI (Kirita et al., 2020). The prolonged decrease of SMCT2 during the injury in-turn supports the merit of luminal D-serine as a metabolite biomarker for AKI and CKD.

In this study, we principally focused on the D-serine transport system at the luminal side of proximal tubules and explained the low urinary D-serine in IRI. Combination of ASCT2 induction and DAAO reduction may result in the elevation of serum D-serine. Future study on the D-serine transport system at the basolateral side is necessary to explain the increase of serum D-serine and complete the picture of D-serine transport system in renal proximal tubules. D-Serine treatment in PAT1- and $\mathrm{B}^{0} \mathrm{AT} 3$-expressing cells showed an increase in cell growth (Figure 5A). PAT1, which is localized at both lysosome and plasma membrane, was

446 reported to transport D-serine while the ability of $\mathrm{B}^{0} \mathrm{AT} 3$ in D-serine uptake is unknown. Both 447 PAT1 and $\mathrm{B}^{0} \mathrm{AT} 3$ may play a role in D-serine secretion in cells. In kidney, PAT1 is located at 448 both apical membranes and inside of the epithelium (maybe also on the basolateral side) of S1 449 segment (The Human Protein Atlas: https://www.proteinatlas.org; updated on Mar 6 ${ }^{\text {th }}, 2020$; 450 Thwaites and Anderson, 2011; Vanslambrouck et al., 2010). $\mathrm{B}^{0} \mathrm{AT} 3$ is found at the apical 

by PAT1 and $\mathrm{B}^{0} \mathrm{AT} 3$ in the kidney needs to be further examined. modification and translocation, proteomics provides a direct association toward the protein

455 function than the transcriptomics does. Although proteomics has been intensively applied for 456 AKI and CKD studies, to our knowledge, none of the studies emphasized the analysis of membrane proteins at the lumen of proximal tubules of the IRI model. Membrane transport proteins are one of the most important targeting groups in the proteomic analysis of AKI because they are directly linked to the metabolites and molecular substances. Our proteomics

460 provides a great hint on membrane transport proteins at hierarchical levels: from individual 461 proteins to systemic scale. The proteome data clearly indicated that homeostasis of inorganic ions is rescued within a short time. On the contrary, the defect of organic compounds is prolonged and requires extensive time to be fully recovered (Figure 3A). These data support the usefulness of the metabolite biomarkers for diagnosis and prognosis of kidney diseases because most metabolite biomarkers are organic compounds which exhibit prolonged defects during IRI. Herein, we predict a new series of membrane transport proteins as biomarkers candidates for AKI and CKD metabolite biomarkers, such as substrates of GLUT5, AQP7, OATP-M1, OAT2, THTR2, and PEPT2. systems for creatinine, a well-known AKI and CKD biomarker. At the apical membranes, creatinine is excreted by transporters MATE1/SLC47A1 and MATE2-K/SLC47A2 and likely et al., 2007). Our proteome data indicated the reduction of MATE1 (Figure 3B), convincing the importance of MATE1 over MATE2-K in creatinine efflux. Decrease of OCTN1, OCTN2, 
and OAT2 in IRI also leads to speculation of their contribution in creatinine transport (Figure

477 3, Table 1-2). Another example is the glucose transport system. In physiological conditions,

478 SGLTs reabsorb glucose and GLUT5 reabsorbs fructose at the luminal side (Ghezzi et al.,

479 2018; Szablewski, 2017). From the proteome, we found a decrease in SGLT1/SLC5A1 and

480 GLUT5 but an increase in GLUT3/SLC2A3 (Figure 3B). GLUT3 exhibits the highest affinity among GLUTs but very low expression in physiological conditions (Simpson et al., 2008). Accordingly, GLUT3 might be a key transporter for metabolic activities in the repair processes. Apart from the kidney, D-serine transport in the brain is contributed by multiple transport systems. The affinity of D-serine transport in astrocyte and retinal glia cultures was found to be in the millimolar range (Dun et al., 2007; Foster et al., 2016). SMCT1 is expressed in neurons, astrocytes, and retinal cells, while SMCT2 is rather restricted to retina (Martin et al., 2007, 2006). Meta-data analysis demonstrated the interaction of SMCT1 and five types of NMDARs (https://amp.pharm.mssm.edu/Harmonizome/; Rouillard et al., 2016). SMCTs are also found in the colon, intestine, and thyroid organs (Ganapathy et al., 2008; Paroder et al.,

490 2006). It is worthwhile to investigate the contribution of SMCTs on D-serine transport systems 491 in those tissues.

Here, we utilize a multi-hierarchical approach to identify D-serine as a hidden substrate of SMCTs. This finding clarifies the physiological transport system of D-serine at the apical membranes of proximal tubules and proposes the D-serine transport in IRI. Our strategy can be applied to the investigation of any transport systems with hidden physiological substrates. 


\section{Materials and Methods}

497

498

499

500

501

502

503

504

505

\section{Materials, animals and graphical analysis}

General chemicals and cell culture media were purchased from Wako Fujifilm.

Chemicals used in mass spectrometry were HPLC or MS grades. Flp-In T-Rex 293 cells, Expi293F cells, Expi293 Expression medium, Lipofectamine 3000, fluorescent-labeled secondary antibodies, and Tyramide SuperBoost kit were from Thermo. Amino acids, fetal bovine serum (FBS), anti-FLAG antibody and anti-FLAG M2 column were from Sigma. Secondary antibodies with HRP conjugated were from Jackson ImmunoResearch. L-[ $\left.{ }^{3} \mathrm{H}\right]$ Serine, D- $\left[{ }^{3} \mathrm{H}\right]$ serine, L- $\left[{ }^{3} \mathrm{H}\right]$ alanine, and D- $\left[{ }^{3} \mathrm{H}\right]$ alanine were from Moravek. L- $\left[{ }^{3} \mathrm{H}\right]$ Glutamic acid, D$\left[{ }^{3} \mathrm{H}\right]$ glutamic acid, L- $\left[{ }^{14} \mathrm{C}\right]$ tyrosine, D- $\left[{ }^{14} \mathrm{C}\right]$ tyrosine, DL- $\left[{ }^{3} \mathrm{H}\right]$ lactic acid, $\left[{ }^{3} \mathrm{H}\right]$ propionic acid, $\left[{ }^{14} \mathrm{C}\right]$ nicotinic acid and $\left[{ }^{14} \mathrm{C}\right]$ uric acid were from American Radiolabeled Chemicals. AntiSGLT2 and anti-Na ${ }^{+} / \mathrm{K}^{+}$-ATPase antibodies were obtained from Santa Cruz Biotechnology.

All animal experiments were carried out following institutional guidelines under approval by the Animal Experiment Committees of Nara Medical University and Keio University, Japan.

Unless otherwise indicated, data shown in all figures are mean \pm standard error of the representative data from three independent experiments. Statistical differences and p-values were determined using the unpaired Student $t$ test. Graphs, statistical significance, and kinetics were analyzed and plotted by GraphPad Prism 8.3.

\section{Plasmid construction}

In this study, we used the cDNA of human SLC5A8/SMCT1 clone "NM_145913". We generated the clone NM_145913 from the clone AK313788 (NBRC, NITE, Kisarazu, Japan). 
and BamHI sites. The clone "pCMV14-SMCT1" NM_145913 was subsequently generated by site-directed mutagenesis. Human SLC5A12/SMCT2 cDNA (NM_178498; Sino Biological Inc.) was amplified by PCR and cloned into p3XFLAG-CMV14 via KpnI and BamHI sites to generate "pCMV14-SMCT2”. Human expression clones of SLC7A10/Asc-1 (NM_019849),

(NM_003039), SLCO4C1/OATP-M1 (NM_180991), SLC22A13/OAT10 (NM_004256),

SLC22A7/OAT2 (NM_153320), SLC6A18/B ${ }^{0}$ AT3 (NM_182632), SLC15A2/PEPT2

528 (NM_021082), and TMEM27/Collectrin (NM_0202665) were obtained from GenScript and

RIKEN BRC through the National BioResource Project of the MEXT/AMED, Japan. Mouse

Asct2 (mAsct2, NM_009201) TrueORF clone was obtained from OriGene. p3XFLAG-

CMV14 empty vector was used for Mock production. pcDNA5-SMCT1 and pcDNA5-SMCT2

532 used for generation of SMCT1- and SMCT2-stable cell lines, respectively, were constructed

533 by assembling the PCR products of SMCT1 or SMCT2 into pcDNA5/FRT/TO (Thermo) by

534 HiFi DNA Assembly Cloning kit.

\section{Antibody (Ab) production}

Anti-human ASCT2 (hASCT2) and anti-mAsct2 Abs were self-produced. First, we generated pET47b(+)-GST. The fragment encoding GST was amplified by using pET49b(+) as the template. The GST fragment was cloned into $\mathrm{pET} 47 \mathrm{~b}(+)$ via NotI and $\mathrm{XhoI}$ restriction

539 sites. To obtain the antigen for anti-hASCT2 Ab, the PCR products corresponding to amino 540 acid residues 7-20 of hASCT2 were amplified and cloned into pET47b(+)-GST to obtain GST-

541 fusion protein. For antigens from mAsct2, both N-terminal (mAsct2(NT), amino acid residues

$5421-38)$ and C-terminal (mAsct2(CT), amino acid residues 521 - 553) fragments were fused 543 with GST by cloning into pET47b(+)-GST or pET49b(+), respectively (Cosmo Bio Co., Ltd). 
544 The GST-fusion antigens were expressed in E. coli BL21(DE3) and purified by Glutathione

545 Sepharose 4B (GE Healthcare) as described previously (Nagamori et al., 2016a). The antigens

546 were used to immunize rabbits to obtain anti-sera were obtained (Cosmo Bio).

Anti-hASCT2 Ab was purified from the anti-sera using HiTrap Protein G HP (GE

548 Healthcare) following the manufacturer's protocol. After purification, the antibody was dialyzed against PBS pH 7.4 and adjusted concentration to $1 \mathrm{mg} / \mathrm{mL}$.

Anti-mAsct2(NT) and anti-mAsct2(CT) Abs were purified by using two-step purifications. First, affinity columns of GST-fused mAsct2(NT)-antigen and GST-fused mAsct2(CT)-antigen were made by conjugated the antigens with HiTrap NHS-activated HP (GE Healthcare) following the manufacturer's protocol. To purify anti-mAsct2(NT) Ab, the anti-sera was subjected to the first purification by using the GST-fused mAsct2(NT)-antigen affinity-purified anti-mAsct2(NT) Ab was obtained. Purification of anti-mAsct2(CT) Ab was performed in the same way as mAsct2(NT) Ab but used GST-fused mAsct2(CT)-antigen column followed by GST-fused mAsct2(NT)-antigen column.

Ischemia-reperfusion injury (IRI) model and isolation of brush border membrane vesicles (BBMVs) for mass spectrometry analysis experimental procedures for the IRI model. Ischemia-reperfusion was performed as previously

564 described (Sasabe et al., 2014). Before IRI induction, right kidney was removed. After 12 days, the mice were grouped by randomization. Ischemia was operated for $45 \mathrm{~min}$ by clamping the vessel under anesthesia with pentobarbital. After that, the vessel clamp was removed, and the 
568 At 4 and 8 hours after reperfusion, mice were anesthetized with isoflurane and euthanized by

569 perfusion with PBS $\mathrm{pH} 7.4$. The kidney was removed and stored at $-80{ }^{\circ} \mathrm{C}$ until use.

2007). Frozen kidneys were minced into fine powders by using a polytron-type homogenizer

572 (Physcotron, Microtec) in the homogenization buffer containing $20 \mathrm{mM}$ Tris-HCl, pH 7.6, 250

mM sucrose, 1 mM EDTA and cOmplete EDTA-free protease inhibitor cocktail (Roche). After

low-speed centrifugation at $1,000 \times \mathrm{g}$ and $3,000 \times \mathrm{g}$, the supernatant was collected and incubated

with $11 \mathrm{mM} \mathrm{CaCl}_{2}$ for $20 \mathrm{~min}$ on ice with mild shaking. The supernatant was ultra-centrifuged

at $463,000 \times \mathrm{g}$ for $15 \mathrm{~min}$ at $4{ }^{\circ} \mathrm{C}$. The pellet was resuspended in the homogenization buffer and

$\mathrm{mM}$ Tris- $\mathrm{HCl} \mathrm{pH} 7.6$ and $250 \mathrm{mM}$ sucrose. Membrane proteins of BBMVs were enriched by

to sample preparation for mass spectrometry.

\section{Cell culture, transfection, and generation of stable cell lines}

HEK293 and Flp-In T-Rex 293 cells were cultured in DMEM supplemented with $10 \%$

$583(\mathrm{v} / \mathrm{v}) \mathrm{FBS}, 100$ units $/ \mathrm{mL}$ penicillin $\mathrm{G}$, and $100 \mu \mathrm{g} / \mathrm{mL}$ streptomycin $(\mathrm{P} / \mathrm{S})$, and routinely maintained at $37{ }^{\circ} \mathrm{C}, 5 \% \mathrm{CO}_{2}$ and humidity. For transfection experiments, the cells were seeded in antibiotic-free media for one day prior to transfection to obtain approximately $40 \%$ of DNA : P3000 : Lipofectamine 3000 is $1.0 \mu \mathrm{g}: 2.0 \mu \mathrm{L}: 1.5 \mu \mathrm{L}$. The ratio of siRNA : 
$150 \mathrm{mg} / \mathrm{L}$ hygromycin B for positive clone selection. Mock cells were generated in the same experiments.

Wild-type and ASCT2-knockout HAP1 cells (Horizon Discovery) were cultured in and humidity. using PEI MAX pH 6.9 (MW 40,000; Polysciences) and cultured for two days.

\section{Mass spectrometry}

Mass spectrometry of mouse BBMVs was performed as described previously with some modification (Uetsuka et al., 2015). After preparing urea-washed BBMVs, the samples UHPLC (Michrom Bioresources). The HPLC apparatus was equipped with a trap column (L-

611 column ODS, $0.3 \times 5$ mm, CERI) and a C18 packed tip column (100 $\mu \mathrm{m}$ ID; Nikkyo Technos).

612 Raw data from four fractions were analyzed using Proteome Discoverer 2.2 (Thermo) and

613 Mascot 2.6.2 (Matrix Science). Data from four fractions were combined and searched for

614 identified proteins from the UniProt mouse database (released in March 2019). The maximum 615 number of missed cleavages, precursor mass tolerance, and fragment mass tolerance were set 
616 to 3, $10 \mathrm{ppm}$ and $0.01 \mathrm{Da}$, respectively. The carbamidomethylation Cys was set as a fixed

617 modification. Oxidation of Met and deamidation of Asn and Gln were set as variable

618 modifications. A filter (false discovery rate $<1 \%$ ) was applied to the resulting data. For each

619 mouse sample, the analysis was conducted twice and the average was used. One data set was

620 composed of 3 samples from each operation condition $(n=3)$.

Mass spectrometry of HEK293 cells was analyzed from crude membrane fractions.

Membrane fractions from HEK293 cells were prepared from 3-day cultured cells as described

(Nagamori et al., 2016b). Membrane proteins were enriched by the urea wash method, and

tryptic peptides were subject for analysis as described above.

\section{Proteome data analysis and availability}

Protein localization and functional categories were determined by Ingenuity pathway analysis (IPA, Qiagen). The prediction of transmembrane regions was acquired using the segments was evaluated based on related literature and The Human Protein Atlas (http://www.proteinatlas.org: updated Dec 19, 2019). the biological networks were analyzed using IPA. Molecules from the dataset that met the cutoff of the Ingenuity Knowledge Base were considered for the analysis. A right-tailed

634 Fisher's Exact Test was used to calculate the p-value determining the probability (z-scores) of 635 the biological function or the toxicity function assignment (IPA). The networks derived from 636 IPA were simplified by omitting the proteins in canonical pathways that were not detected and 637 not key regulators. Networks with the shared regulators were merged and displayed in the 638 Figures. 
Wiriyasermkul, et al.

\section{Effect of cell D-serine on cell growth}

HEK293 cells were seeded into 96-well-plate at 10,000 cells/well. Transient

643 transfection was performed 12 hours after seeding followed by L- or D-serine treatment 12

644 hours after that. In the case of FlpInTR-stable cell lines, ASCT2 siRNA was transfected 12

645 hours after seeding, if needed. Dox was added one day after seeding followed by treatment

646 with L- or D-serine (in the presence or absence of ibuprofen as indicated) 10 hours after adding

647 Dox. The cells were further maintained for 2 days. Cell growth was examined by XTT assay.

648 In one reaction, $50 \mu \mathrm{L}$ of $1 \mathrm{mg} / \mathrm{mL}$ XTT (2,3-Bis-(2-Methoxy-4-Nitro-5-Sulfophenyl)-2H-

649 Tetrazolium-5-Carboxanilide) (Biotium) was mixed with $5 \mu \mathrm{L}$ of $1.5 \mathrm{mg} / \mathrm{mL}$ phenazine

650 methosulfate. The mixture was applied to the cells and incubated for 4 hours at $37^{\circ} \mathrm{C}$ in the

651 cell culture incubator. Cell viability was evaluated by measuring the absorbance at $450 \mathrm{~nm}$.

652 Cell growth in serine treatment samples was compared to the control (without serine treatment).

653 For transporter screening, the growth of the transfected cells at a specific D-serine concentration was compared to that of Mock after normalization with no treatment.

\section{Transport assay in cultured cells}

Transport assay in cells was performed as described previously with some modifications (Nagamori et al., 2016b). Briefly, for D- $\left[{ }^{3} \mathrm{H}\right]$ serine transport in HEK293 cells,

658 the cells were seeded into poly-D-lysine-coated 24 -well plates at $1.2 \times 10^{5}$ cells/well and

659 cultured for three days. Uptake of $10 \mu \mathrm{M}(100 \mathrm{Ci} / \mathrm{mol})$ or $100 \mu \mathrm{M}(10 \mathrm{Ci} / \mathrm{mol}) \mathrm{D}-\left[{ }^{3} \mathrm{H}\right] \mathrm{serine}$ 660 was measured in PBS pH 7.4 at $37{ }^{\circ} \mathrm{C}$ at the indicated time points. After termination of the assay, the cells were lysed. An aliquot was subjected to measure protein concentration, and the

662 remaining lysate was mixed with Optiphase HiSafe 3 (PerkinElmer). The radioactivity was 663 monitored using a $\beta$-scintillation counter (LSC-8000, Hitachi). In the transport assay with or 664 without $\mathrm{Na}^{+}, \mathrm{Na}^{+}$-HBSS, or $\mathrm{Na}^{+}$-free HBSS (choline-Cl substitution) were used instead of PBS. 
667 Dox for two days. For the ASCT2 knockdown experiment, ASCT2-siRNA was transfected 12 668 hours prior to Dox induction. The time course of $100 \mu \mathrm{M} \mathrm{D}-\left[{ }^{3} \mathrm{H}\right]$ serine transport $(10 \mathrm{Ci} / \mathrm{mol})$ 669 was measured $37^{\circ} \mathrm{C}$ for $5-20 \mathrm{~min}$. Inhibition assay was performed by adding the test 670 inhibitors at the same time with D- $\left[{ }^{3} \mathrm{H}\right]$ serine substrate. Kinetics of D- $\left[{ }^{3} \mathrm{H}\right]$ serine transport were 671 examined by the uptake of $\mathrm{D}-\left[{ }^{3} \mathrm{H}\right]$ serine at the concentration of $0.5-8 \mathrm{mM}(0.125-2 \mathrm{Ci} / \mathrm{mol})$ 672 for $10 \mathrm{~min}$ at $37^{\circ} \mathrm{C}$.

Transport of D- $\left[{ }^{3} \mathrm{H}\right]$ serine in wild-type and $A S C T 2$-knockout HAP1 was performed in a similar way to HEK293 and FlpInTR-stable cells but without the process of transfection. $\mathrm{mM} \mathrm{NaCl}, 10 \%$ (v/v) glycerol, and protease inhibitor cocktail (Roche). The crude membrane

680 fraction was derived from sonication and ultracentrifugation (sonication method). Membrane 681 proteins were extracted from the crude membrane fraction with $2 \%(\mathrm{w} / \mathrm{v})$ DDM and ultracentrifugation. hSMCT1 was purified by anti-FLAG M2 affinity column. Unbound proteins were washed out by $20 \mathrm{mM}$ Tris- $\mathrm{HCl} \mathrm{pH}$ 7.4, $200 \mathrm{mM} \mathrm{NaCl}, 10 \%$ (v/v) glycerol, and $0.05 \%(\mathrm{w} / \mathrm{v})$ DDM then hSMCT1 was eluted by 3xFLAG peptide in the washing buffer. Purified hSMCT1 was concentrated by Amicon Ultra Centrifugal Filters 30K (Millipore). 
$697\left[{ }^{3} \mathrm{H}\right]$ glutamic acid and D- $\left[{ }^{3} \mathrm{H}\right]$ glutamic acid; and $20 \mathrm{Ci} / \mathrm{mol}$ for $\left[{ }^{3} \mathrm{H}\right]$ propionic acid. In the substrates.

\section{Transport assay in mouse BBMVs}

Both left and right kidneys were taken out from the 8 weeks old male wild-type

C57BL/6J mice (Japan SLC) after PBS perfusion and frozen until use. After mincing and homogenizing the frozen kidneys (as in the above section) in the buffer containing $20 \mathrm{mM}$ Trisof BBMVs was resuspended in the suspension buffer $(10 \mathrm{mM}$ Tris- $\mathrm{HCl}, \mathrm{pH} 7.6,100 \mathrm{mM}$ mannitol, and $100 \mathrm{mM} \mathrm{KCl}$ ). In the L-glutamine preloading experiment, the BBMVs were mixed with $4 \mathrm{mM} \mathrm{L-glutamine}$ on ice for 3 hours, centrifuged at 21,000 $\times \mathrm{g}$ for $20 \mathrm{~min}$, and resuspended in the suspension buffer.

711 valinomycin was added into the BBMV samples and the BBMVs were kept at room

712 temperature for 2 minutes. Transport assay was examined by diluting $100 \mu \mathrm{g}$ BBMVs in 100 
$714 \mathrm{Na}^{+}$-free condition, $50 \mathrm{mM}$ mannitol and $5 \mu \mathrm{M}$ valinomycin) containing $10 \mu \mathrm{M} \mathrm{D}-\left[{ }^{3} \mathrm{H}\right]$ serine

$715(100 \mathrm{Ci} / \mathrm{mol})$. The reaction was incubated at $30{ }^{\circ} \mathrm{C}$ at an indicated time, then terminated by the

716 addition of ice-cold buffer containing $10 \mathrm{mM}$ Tris-HCl pH 7.6 and $200 \mathrm{mM}$ mannitol, and

717 filtered through $0.45 \mu \mathrm{m}$ nitrocellulose filter (Millipore), followed by washing with the same

718 buffer once. The membranes were soaked in Clear-sol I (Nacalai Tesque), and the radioactivity

719 on the membrane was monitored. For the inhibition experiments, the tested inhibitors were

720 added into the $\mathrm{D}-\left[{ }^{3} \mathrm{H}\right]$ serine substrate solution at the same time.

\section{Western Blot analysis}

Expressions of targeting proteins from membrane fractions were verified by Western

blot analysis as described (Nagamori et al., 2016b). Membrane fractions from cultured cell

pellets were prepared by sonication. BBMVs were prepared by the magnesium precipitation

method. Membrane proteins were dissolved in $1 \% \mathrm{w} / \mathrm{v}$ DDM prior to the addition of the SDS-

PAGE sample buffer. Signals of chemiluminescence (Immobilon Forte Western HRP

substrate; Millipore) were visualized by ChemiDoc MP Imaging system (Bio-Rad).

\section{Immunofluorescent staining of mouse kidneys}

The 8 weeks old male wild-type C57BL/6J mice (Japan SLC) were anesthetized and

730 fixed by anterograde perfusion via the aorta with $4 \% \mathrm{w} / \mathrm{v}$ paraformaldehyde in $0.1 \mathrm{M}$ sodium

731 phosphate buffer $\mathrm{pH}$ 7.4. The kidneys were dissected, post-fixed in the same buffer for two

732 days, and cryoprotected in $10 \%, 20 \%$, and $30 \% \mathrm{w} / \mathrm{v}$ sucrose. Frozen kidney sections were

733 cut at $7 \mu \mathrm{m}$ thickness in a cryostat (Leica) and mounted on MAS-coated glass slides

734 (Matsunami). The sections were placed in antigen retrieval buffer (10 $\mathrm{mM}$ citrate and $10 \mathrm{mM}$

735 sodium Citrate), autoclaved at $121{ }^{\circ} \mathrm{C}$ for $5 \mathrm{~min}$ and washed by TBS-T (Tris-buffered saline

736 (TBS) with $0.1 \% \mathrm{v} / \mathrm{v}$ Tween 20). Immunostaining was done by serial incubation with each

737 antibody as below. 
Wiriyasermkul, et al.

739 hydrogen peroxide solution for $10 \mathrm{~min}$, washed with TBS, and incubated in Blocking One

740 Histo (Nacalai tesque) for $15 \mathrm{~min}$. The samples were then incubated with mouse anti-SGLT2

741 antibody diluted in immunoreaction enhancer B solution (Can Get Signal immunostain,

742 TOYOBO) overnight at $4{ }^{\circ} \mathrm{C}$. Signal was enhanced by Alexa Fluor 568 Tyramide SuperBoost

743 (TSA) kit, goat anti-mouse IgG, following the manufacture's instruction (Thermo). The

744 antibodies were then stripped by citrate/acetate-based buffer, $\mathrm{pH} 6.0$, containing $0.3 \% \mathrm{w} / \mathrm{v}$ SDS

745 at $95{ }^{\circ} \mathrm{C}$ for 10 min (Buchwalow et al., 2018), washed by TBS, and incubated with Blocking

746 One Histo. mSglt2 staining was done by conventional staining method (Nagamori et al., 2016b).

747 The samples were incubated with rabbit anti-mAsct2(NT) antibody diluted in immunoreaction

748 enhancer A solution (Can Get Signal immunostain) overnight at $4{ }^{\circ} \mathrm{C}$. After washing with TBS-

$749 \mathrm{~T}$, the specimens were incubated with Alexa Fluor 488-labeled donkey anti-rabbit IgG.

For mAsct2 and mAgt1 co-immunostaining, signals of both antibodies were enhanced

by TSA kit. First, the specimens were incubated with rabbit anti-mAGT1(G) antibody

(Nagamori et al., 2016a) overnight at $4{ }^{\circ} \mathrm{C}$ followed by Alexa Fluor 568 TSA kit, goat antirabbit. The antibodies were then stripped. The specimens were incubated with rabbit antimAsct2(NT) overnight at $4{ }^{\circ} \mathrm{C}$ and then repeated the steps of TSA kit using Alexa Fluor 488, goat anti-rabbit.

Staining of mAsct2 and $\mathrm{Na}^{+} / \mathrm{K}^{+}$-ATPase was performed without TSA enhancement. After blocking by Blocking One Histo, the samples were incubated with rabbit antimAsct2(NT) antibody diluted in immunoreaction enhancer A solution overnight. The samples were washed with TBS-T, incubated with Alexa Fluor488-labeled donkey anti-rabbit IgG, and washed again. Non-specific staining was blocked by Blocking One Histo and the specimens were then incubated with mouse anti- $\mathrm{Na}^{+} / \mathrm{K}^{+}$-ATPase antibody diluted in immunoreaction 

made available under aCC-BY 4.0 International license.

Wiriyasermkul, et al.

762 enhancer B solution overnight at $4{ }^{\circ} \mathrm{C}$. The specimens were washed with TBS-T, incubated

763 with Alexa Fluor568-labeled goat anti-mouse IgG for 1 hour.

All specimens were washed with TBS-T and mounted with Fluoromount (Diagnostic

765 Biosystems). Imaging was detected using a KEYENCE BZ-X710 microscope. Images were processed by using ImageJ ver. $1.51(\mathrm{NIH})$. 


\section{Acknowledgments}

We greatly appreciate Noriyoshi Isozumi for preliminary proteomic analysis and

769 Rikako Furuya for crucial discussion. We would like to thank Saki Takeshita, Yuki Mori,

770 Junko Iwatani, and Yuika Shimo for technical assistance. We are especially grateful to

771 Yoshinori Moriyama for critical reading and suggestions. This work is partly supported by

772 MEXT/JSPS KAKENHI under grant number 19K07373 to P.W.; research grants from

773 Shiseido Company, Ltd. and AMED under grant numbers JP20ek031001 and JP20gm0810010 774 to S.N.

\section{Competing interests}

776

A patent has been applied by KAGAMI Inc., Nara Medical University, and NIBIOHN

with P.W., S.M., P.K., T.K., M.M., and S.N. as inventors based on this research. KAGAMI

Inc. was founded in 2019 to implement the technologies in medicine.

\section{Author contributions}

Pattama Wiriyasermkul-Conceptualization, Methodology, Investigation, Validation,

781 Formal analysis, Data curation, Visualization, Writing — original draft, Writing — review and

782 editing

783 Satomi Moriyama - Investigation, Validation, Formal analysis, Visualization

784 Yoko Tanaka-Investigation, Validation, Formal analysis

785 Pornparn Kongpracha - Investigation, Validation, Formal analysis, Data curation

786 Nodoka Nakamae - Investigation, Formal analysis

787 Masataka Suzuki-Investigation, Resources

788 Tomonori Kimura-Resources, Methodology

789 Masashi Mita-Conceptualization, Funding acquisition 
790 Jumpei Sasabe - Investigation, Resources, Methodology

791 Shushi Nagamori - Conceptualization, Methodology, Validation, Data curation, Supervision,

792 Resources, Funding acquisition, Project administration, Writing — original draft, Writing-

793 review and editing

794 All authors contributed to the final manuscript. 


\section{References}

796

Biber J, Stieger B, Stange G, Murer H. 2007. Isolation of renal proximal tubular brush-border membranes. Nature Protocols 2:1356-1359. doi:10.1038/nprot.2007.156

Bröer A, Rahimi F, Bröer S. 2016. Deletion of amino acid transporter ASCT2 (SLC1A5) reveals an essential role for transporters SNAT1 (SLC38A1) and SNAT2 (SLC38A2) to sustain glutaminolysis in cancer cells. J Biol Chem 291:13194-13205. doi:10.1074/jbc.M115.700534

Buchwalow I, Samoilova V, Boecker W, Tiemann M. 2018. Multiple immunolabeling with antibodies from the same host species in combination with tyramide signal amplification. Acta Histochemica 120:405-411. doi:10.1016/j.acthis.2018.05.002

Bukhari FJ, Moradi H, Gollapudi P, Ju Kim H, Vaziri ND, Said HM. 2011. Effect of chronic kidney disease on the expression of thiamin and folic acid transporters. Nephrology Dialysis Transplantation 26:2137-2144. doi:10.1093/ndt/gfq675

Cheng G, Zhong M, Kawaguchi R, Kassai M, Al-Ubaidi M, Deng J, Ter-Stepanian M, Sun H. 2014. Identification of PLXDC1 and PLXDC2 as the transmembrane receptors for the multifunctional factor PEDF. eLife 3:e05401. doi:10.7554/eLife.05401

Chevalier RL. 2016. The proximal tubule is the primary target of injury and progression of kidney disease: role of the glomerulotubular junction. American Journal of PhysiologyRenal Physiology 311:F145-F161. doi:10.1152/ajprenal.00164.2016

Chu X, Bleasby K, Chan GH, Nunes I, Evers R. 2016. The complexities of interpreting reversible elevated serum creatinine levels in drug development: Does a correlation with inhibition of renal transporters exist? Drug Metabolism and Disposition 44:14981509. doi:10.1124/dmd.115.067694 
Wiriyasermkul, et al.

818 de Carvalho FD, Quick M. 2011. Surprising substrate versatility in SLC5A6: $\mathrm{Na}^{+}$-coupled $\mathrm{I}^{-}$

819 transport by the human $\mathrm{Na}^{+} /$multivitamin transporter (hSMVT). Journal of Biological

$820 \quad$ Chemistry 286:131-137. doi:10.1074/jbc.M110.167197

821 Devarajan P, Jefferies JL. 2016. Progression of chronic kidney disease after acute kidney injury. Progress in Pediatric Cardiology 41:33-40. doi:10.1016/j.ppedcard.2015.12.006

DiGiacomo V, Meruelo D. 2016. Looking into laminin receptor: critical discussion regarding the non-integrin 37/67-kDa laminin receptor/RPSA protein: Looking into laminin receptor. Biological Reviews 91:288-310. doi:10.1111/brv.12170

Djamali A, Vidyasagar A, Adulla M, Hullett D, Reese S. 2008. Nox-2 is a modulator of fibrogenesis in kidney allografts: Nox-2 and kidney allograft fibrosis. American

Douard V, Ferraris RP. 2008. Regulation of the fructose transporter GLUT5 in health and disease. American Journal of Physiology-Endocrinology and Metabolism 295:E227E237. doi:10.1152/ajpendo.90245.2008

Dun Y, Mysona B, Itagaki S, Martin-Studdard A, Ganapathy V, Smith SB. 2007. Functional and molecular analysis of D-serine transport in retinal Müller cells. Experimental Eye

Eddy S, Mariani LH, Kretzler M. 2020. Integrated multi-omics approaches to improve classification of chronic kidney disease. Nature Review Nephrology.

838 Emond MJ, Louie T, Emerson J, Zhao W, Mathias RA, Knowles MR, Wright FA, Rieder MJ, Tabor HK, Nickerson DA, Gibson RL, Bamshad MJ. 2012. Exome sequencing of extreme phenotypes identifies DCTN4 as a modifier of chronic Pseudomonas 
aeruginosa infection in cystic fibrosis. Nature Genetics 44:886-889.

842 doi:10.1038/ng.2344

843 Famulski KS, Reeve J, de Freitas DG, Kreepala C, Chang J, Halloran PF. 2013. Kidney transplants with progressing chronic diseases express high levels of acute kidney injury

Formisano TM, Van Winkle LJ. 2016. At least three rransporters likely mediate threonine uptake needed for mouse embryonic stem cell proliferation. Frontiers in Cell and

Foster AC, Farnsworth J, Lind GE, Li Y-X, Yang J-Y, Dang V, Penjwini M, Viswanath V, Developmental Biology 4:17. doi:10.3389/fcell.2016.00017

Fu Y, Tang C, Cai J, Chen G, Zhang D, Dong Z. 2018. Rodent models of AKI-CKD transition. doi:10.1152/ajprenal.00199.2018 activation by cytidine or its analogs. International Immunology 31:167-173. doi:10.1093/intimm/dxy075

862 Ganapathy V, Thangaraju M, Gopal E, Martin PM, Itagaki S, Miyauchi S, Prasad PD. 2008. 
Gopal E, Umapathy NS, Martin PM, Ananth S, Gnana-Prakasam JP, Becker H, Wagner CA, SMCT2 (SLC5A12) and expression pattern of the transporter in kidney. Biochimica et

Hasegawa H, Masuda N, Natori H, Shinohara Y, Ichida K. 2019. Pharmacokinetics and toxicokinetics of D-serine in rats. Journal of Pharmaceutical and Biomedical Analysis D-Serine reflects kidney function and diseases. Scientific Reports 9:5104. doi:10.1038/s41598-019-41608-0 McCulloch J, Horsburgh K. 2012. Proteomic analysis of mitochondria in APOE transgenic mice and in response to an ischemic challenge. Journal of Cerebral Blood dynamics, and toxicity. Drug Metabolism and Pharmacokinetics 23:236-242. 
Kandasamy P, Gyimesi G, Kanai Y, Hediger MA. 2018. Amino acid transporters revisited: doi:10.1016/j.tibs.2018.05.003

Karihaloo A, Kale S, Rosenblum ND, Cantley LG. 2004. Hepatocyte growth factor-mediated renal epithelial branching morphogenesis is regulated by glypican-4 expression. Molecular and Cell Biology 24:8745-8752. doi:10.1128/MCB.24.19.8745-8752.2004 mediator of ischemia reperfusion injury: Nox2 and IRI. American Journal of Transplantation 15:2888-2899. doi:10.1111/ajt.13368 Isaka Y. 2016. Chiral amino acid metabolomics for novel biomarker screening in the prognosis of chronic kidney disease. Scientific Reports 6:26137. doi:10.1038/srep26137

902 Kimura T, Hesaka A, Isaka Y. 2020. Utility of D-serine monitoring in kidney disease. Biochimica et Biophysica Acta (BBA) - Proteins and Proteomics 1868:140449. doi:10.1016/j.bbapap.2020.140449

Kirita Y, Wu H, Uchimura K, Wilson PC, Humphreys BD. 2020. Cell profiling of mouse acute kidney injury reveals conserved cellular responses to injury. Proceeding of the National

909 Kovacevic L, Lu H, Caruso JA, Govil-Dalela T, Thomas R, Lakshmanan Y. 2017. Marked 910 increase in urinary excretion of apolipoproteins in children with nephrolithiasis 911 associated with hypercalciuria. Pediatric Nephrology 32:1029-1033. Academy of Sciences of the United States of America 117:15874-15883. doi:10.1073/pnas.2005477117 doi:10.1007/s00467-016-3576-1 
913 Kragh-Hansen U, Sheikh MI. 1984. Serine uptake by luminal and basolateral membrane

914 vesicles from rabbit kidney. The Journal of Physiology 354:55-67.

$915 \quad$ doi:10.1113/jphysiol.1984.sp015361

916 Kruzel ML, Zimecki M, Actor JK. 2017. Lactoferrin in a context of inflammation-induced pathology. Frontiers in Immunology 8:1438. doi:10.3389/fimmu.2017.01438

918 Lee S-Y, Shin J-A, Kwon HM, Weiner ID, Han K-H. 2011. Renal ischemia-reperfusion injury 919 causes intercalated cell-specific disruption of occludin in the collecting duct. Histochemistry and Cell Biology 136:637-647. doi:10.1007/s00418-011-0881-4

921 Lee Y, Wiriyasermkul P, Jin C, Quan L, Ohgaki R, Okuda S, Kusakizako T, Nishizawa T, Oda K, Ishitani R, Yokoyama T, Nakane T, Shirouzu M, Endou H, Nagamori S, Kanai Y, Nureki O. 2019. Cryo-EM structure of the human L-type amino acid transporter 1 in complex with glycoprotein CD98hc. Nature Structural \& Molecular Biology 26:510-

Liu C, Wang J, Hu J, Fu B, Mao Z, Zhang H, Cai G, Chen X, Sun X. 2020. Extracellular vesicles for acute kidney injury in preclinical rodent models: a meta-analysis. Stem Cell Research \& Therapy 11:11. doi:10.1186/s13287-019-1530-4

929 Lu Y, Chen Xiaoniao, Yin Z, Zhu S, Wu D, Chen Xiangmei. 2016. Screening for potential 930 serum biomarkers in rat mesangial proliferative nephritis. Proteomics 16:1015-1022. doi:10.1002/pmic.201500405

932 Luan H, Wang C, Sun J, Zhao L, Li L, Zhou B, Shao S, Shen X, Xu Y. 2020. Resolvin D1 protects against ischemia/reperfusion-induced acute kidney injury by increasing Treg

934 percentages via the ALX/FPR2 pathway. Frontiers in Physiology 11:285. doi:10.3389/fphys.2020.00285 
936 Ma C, Guo Y, Zhang Y, Duo A, Jia Y, Liu C, Li B. 2018. PAFAH1B2 is a HIF1a target gene and promotes metastasis in pancreatic cancer. Biochemical and Biophysical Research Communications 501:654-660. doi:10.1016/j.bbrc.2018.05.039

939 Makridakis M, Kontostathi G, Petra E, Stroggilos R, Lygirou V, Filip S, Duranton F, Mischak H, Argiles A, Zoidakis J, Vlahou A. 2020. Multiplexed MRM-based protein quantification of putative prognostic biomarkers for chronic kidney disease progression

Martin PM, Gopal E, Ananth S, Zhuang L, Itagaki S, Prasad BM, Smith SB, Prasad PD, in plasma. Scientific Reports 10:4815. doi:10.1038/s41598-020-61496-z

947 Martin PM, Dun Y, Mysona B, Ananth S, Roon P, Smith SB, Ganapathy V. 2007. Expression Ganapathy V. 2006. Identity of SMCT1 (SLC5A8) as a neuron-specific $\mathrm{Na}^{+}$-coupled transporter for active uptake of L-lactate and ketone bodies in the brain. Journal of

Martins JR, Penton D, Peyronnet R, Arhatte M, Moro C, Picard N, Kurt B, Patel A, Honoré E, Neurochemistry 98:279-288. doi:10.1111/j.1471-4159.2006.03878.x of the sodium-coupled monocarboxylate transporters SMCT1 (SLC5A8) and SMCT2 (SLC5A12) in retina. Investigative Ophthalmology \& Visual Science 48:3356. SS, Husi H, Zoidakis J, Klingele M, Herget-Rosenthal S. 2018. Proteomics and metabolomics for AKI diagnosis. Seminars in Nephrology 38:63-87. doi:10.1016/j.semnephrol.2017.09.007 
959 Matsuo H, Chiba T, Nagamori S, Nakayama A, Domoto H, Phetdee K, Wiriyasermkul P,

960 Kikuchi Y, Oda T, Nishiyama J, Nakamura T, Morimoto Y, Kamakura K, Sakurai Y,

961 Nonoyama S, Kanai Y, Shinomiya N. 2008. Mutations in glucose transporter 9 gene

962 SLC2A9 cause renal hypouricemia. The American Journal of Human Genetics 83:744-

963 751. doi:10.1016/j.ajhg.2008.11.001

964 Metzner L, Kottra G, Neubert K, Daniel H, Brandsch M. 2005. Serotonin, L-tryptophan, and tryptamine are effective inhibitors of the amino acid transport system PAT1. FASEB Journal 19:1468-1473. doi:10.1096/fj.05-3683com

967 Mocker A, Hilgers KF, Cordasic N, Wachtveitl R, Menendez-Castro C, Woelfle J, Hartner A, 968 Fahlbusch FB. 2019. Renal chemerin expression is induced in models of hypertensive nephropathy and glomerulonephritis and correlates with markers of inflammation and fibrosis. International Journal of Molecular Sciences 20:6240. doi:10.3390/ijms20246240

Morehead RP, Fishman WH, Artom C. 1945. Renal injury in the rat following the administration of serine by stomach tube. The American Journal of Pathology 21:803815. Y, Bodoy S, Takafuji K, Okuda S, Kurokawa J, Ohgaki R, Nunes V, Palacín M, Kanai Y. 2016a. Novel cystine transporter in renal proximal tubule identified as a missing partner of cystinuria-related plasma membrane protein $\mathrm{rBAT} / \mathrm{SLC} 3 \mathrm{~A} 1$. Proceeding of

981 Nagamori S, Wiriyasermkul P, Okuda S, Kojima N, Hari Y, Kiyonaka S, Mori Y, Tominaga H, Ohgaki R, Kanai Y. 2016b. Structure-activity relations of leucine derivatives reveal 
critical moieties for cellular uptake and activation of mTORC1-mediated signaling. Amino Acids 48:1045-1058. doi:10.1007/s00726-015-2158-z derived D-serine protects against acute kidney injury. JCI Insight 3:e97957. doi:10.1172/jci.insight.97957

Okada A, Nangaku M, Jao T-M, Maekawa H, Ishimono Y, Kawakami T, Inagi R. 2017. Dserine, a novel uremic toxin, induces senescence in human renal tubular cells via GCN2 activation. Scientific Reports 7:11168. doi:10.1038/s41598-017-11049-8

Ostermann M, Joannidis M. 2016. Acute kidney injury 2016: diagnosis and diagnostic workup. Critical Care 20:299. doi:10.1186/s13054-016-1478-z

Özkan G, Güzel S, Atar RV, Fidan Ç, Kara SP, Ulusoy Ş. 2019. Elevated serum levels of procollagen C-proteinase enhancer-1 in patients with chronic kidney disease is associated with a declining glomerular filtration rate. Nephrology nep.13521.

1000 Paroder V, Spencer SR, Paroder M, Arango D, Schwartz S, Mariadason JM, Augenlicht LH, Eskandari S, Carrasco N. 2006. $\mathrm{Na}^{+} /$monocarboxylate transport (SMCT) protein expression correlates with survival in colon cancer: Molecular characterization of SMCT. Proceedings of the National Academy of Sciences of the United States of America 103:7270-7275. doi:10.1073/pnas.0602365103 
Pinkaew D, Fujise K. 2017. Fortilin: A Potential target for the prevention and treatment of human diseasesAdvances in clinical chemistry. Advances in Clinical Chemistry 82:265-300. doi:10.1016/bs.acc.2017.06.006 metabolic gateways in adiposity and insulin resistance control. Cell Cycle 10:15481556. doi:10.4161/cc.10.10.15672

Rosenberg D, Artoul S, Segal AC, Kolodney G, Radzishevsky I, Dikopoltsev E, Foltyn VN, Inoue R, Mori H, Billard J-M, Wolosker H. 2013. Neuronal D-serine and glycine release via the Asc-1 transporter regulates NMDA receptor-dependent synaptic activity. Camilli P. 2016. Control of plasma membrane lipid homeostasis by the extended synaptotagmins. Nature Cell Biology 18:504-515. doi:10.1038/ncb3339 mRNA decay: TTP and BRF proteins in regulated mRNA decay. WIREs RNA 2:42-57. doi:10.1002/wrna.28 S. 2014. Ischemic acute kidney injury perturbs homeostasis of serine enantiomers in the body fluid in mice: Early detection of renal dysfunction using the ratio of serine 
1029 Sasabe J, Miyoshi Y, Rakoff-Nahoum S, Zhang T, Mita M, Davis BM, Hamase K, Waldor MK. 2016. Interplay between microbial D-amino acids and host D-amino acid oxidase modifies murine mucosal defence and gut microbiota. Nature Microbiology 1:16125. doi:10.1038/nmicrobiol.2016.125

1033 Sasabe J, Suzuki M. 2018. Distinctive roles of D-amino acids in the homochiral world: Chirality of amino acids modulates mammalian physiology and pathology. The Keio Journal of Medicine 68:1-16. doi:10.2302/kjm.2018-0001-IR

1036 Scalise M, Pochini L, Console L, Losso MA, Indiveri C. 2018. The human SLC1A5 (ASCT2) amino acid transporter: From function to structure and role in cell biology. Frontiers in Cell and Developmental Biology 6:96. doi:10.3389/fcell.2018.00096

1039

Schrick JJ, Vogel P, Abuin A, Hampton B, Rice DS. 2006. ADP-Ribosylation Factor-Like 3 is involved in kidney and photoreceptor development. The American Journal of Pathology 168:1288-1298. doi:10.2353/ajpath.2006.050941

1042 Schweikhard ES, Ziegler CM. 2012. Amino acid secondary transporters: Toward a common transport system. Current Topics in Membranes 70:1-28. doi:10.1016/B978-0-12394316-3.00001-6

1045 Shen H, Feng S, Lu Y, Jiang L, Yang T, Wang Z. 2020. Correlation between plasma proprotein convertase subtilisin/kexin type 9 and blood lipids in patients with newly diagnosed primary nephrotic syndrome.

Renal Failure 42:405-412. doi:10.1080/0886022X.2020.1756846

1049 Shen H, Lai Y, Rodrigues AD. 2017. Organic anion transporter 2: An enigmatic human solute 1050 carrier. Drug Metabolism and Disposition 45:228-236. doi:10.1124/dmd.116.072264 
1051 Shimomura A, Carone FA, Peterson DR. 1988. Contraluminal uptake of serine in the proximal nephron. Biochimica et Biophysica Acta (BBA) - Biomembranes 939:52-56. doi:10.1016/0005-2736(88)90046-6

Shrestha P, van de Sluis B, Dullaart RPF, van den Born J. 2019. Novel aspects of PCSK9 and lipoprotein receptors in renal disease-related dyslipidemia. Cellular Signaling 55:5364. doi:10.1016/j.cellsig.2018.12.001

Silbernagl S, Völker K, Dantzler WH. 1999. D-Serine is reabsorbed in rat renal pars recta. American Journal of Physiology - Renal Physiology 276:F857-F863.

Simpson IA, Dwyer D, Malide D, Moley KH, Travis A, Vannucci SJ. 2008. The facilitative doi:10.1152/ajprenal.1999.276.6.F857

Sohara E, Rai T, Sasaki S, Uchida S. 2006. Physiological roles of AQP7 in the kidney: Lessons from AQP7 knockout mice. Biochimica et Biophysica Acta (BBA) - Biomembranes 2011. Transcriptional regulation of organic anion transporting polypeptide SLCO4C1 Biomedical Science 24:64. doi:10.1186/s12929-017-0371-7

1072 Tang M, Zhang Kun, Li Y, He Q, Li G, Zheng Q, Zhang Ke-qin. 2018. Mesenchymal stem cells alleviate acute kidney injury by down-regulating $\mathrm{C} 5 \mathrm{a} / \mathrm{C} 5 \mathrm{aR}$ pathway activation. 
Tanihara Y, Masuda S, Sato T, Katsura T, Ogawa O, Inui K. 2007. Substrate specificity of MATE1 and MATE2-K, human multidrug and toxin extrusions $/ \mathrm{H}^{+}$-organic cation antiporters. Biochemical Pharmacology 74:359-371. doi:10.1016/j.bcp.2007.04.010

1079

Thongboonkerd V. 2020. Roles for exosome in various kidney diseases and disorders. Frontiers in Pharmacology 10:1655. doi:10.3389/fphar.2019.01655

1081 Thwaites DT, Anderson CM. 2011. The SLC36 family of proton-coupled amino acid transporters and their potential role in drug transport: SLC36 proton-coupled amino acid transporter family. British Journal of Pharmacology 164:1802-1816.

1084 doi:10.1111/j.1476-5381.2011.01438.x

1085 Uetsuka S, Ogata G, Nagamori S, Isozumi N, Nin F, Yoshida T, Komune S, Kitahara T, 1086

1087

1088

1089 Kikkawa Y, Inohara H, Kanai Y, Hibino H. 2015. Molecular architecture of the stria vascularis membrane transport system, which is essential for physiological functions of the mammalian cochlea. European Journal of Neuroscience 42:1984-2002.

1090 Vanslambrouck JM, Bröer A, Thavyogarajah T, Holst J, Bailey CG, Bröer S, Rasko JEJ. 2010.

1092 Renal imino acid and glycine transport system ontogeny and involvement in doi:10.1111/ejn.12973

1093 developmental iminoglycinuria. Biochemical Journal 428:397-407. doi:10.1042/BJ20091667

1094 Vaziri ND. 2016. HDL abnormalities in nephrotic syndrome and chronic kidney disease. Nature Reviews Nephrology 12:37-47. doi:10.1038/nrneph.2015.180 
1096

1097

1098

1099

1100

1101

1102

1103

1104

1105

1106

1107

1108

1109

1110

1111

1112

1113

1114

1115

1116

1117 Zheng X, Zhang X, Feng B, Sun H, Suzuki M, Ichim T, Kubo N, Wong A, Min LR, Budohn 1118

Wei L, Tominaga H, Ohgaki R, Wiriyasermkul P, Hagiwara K, Okuda S, Kaira K, Kato Y, Oriuchi N, Nagamori S, Kanai Y. 2016. Transport of 3-fluoro-L- $\alpha$-methyl-tyrosine (FAMT) by organic ion transporters explains renal background in $\left[{ }^{18} \mathrm{~F}\right] \mathrm{FAMT}$ positron emission tomography. Journal of Pharmacological Sciences 130:101-109. doi:10.1016/j.jphs.2016.01.001

Wei L, Yu SP, Gottron F, Snider BJ, Zipfel GJ, Choi DW. 2003. Potassium channel blockers attenuate hypoxia- and ischemia-induced neuronal death In Vitro and In Vivo. Stroke 34:1281-1286. doi:10.1161/01.STR.0000065828.18661.FE

Wolosker H. 2018. The nof D-serine signaling. Advances in Pharmacology 82:325-348. doi:10.1016/bs.apha.2017.08.010

Yang H, Zhang X, Xin G. 2018. Investigation of mechanisms of mesenchymal stem cells for treatment of diabetic nephropathy via construction of a miRNA-TF-mRNA network. Renal Failure 40:136-145. doi:10.1080/0886022X.2017.1421556

Yin Y, Long J, Sun Y, Li H, Jiang E, Zeng C, Zhu W. 2018. The function and clinical significance of eIF3 in cancer. Gene 673:130-133. doi:10.1016/j.gene.2018.06.034

Zhang WR, Parikh CR. 2019. Biomarkers of acute and chronic kidney disease. Annual Review of Physiology 81:309-333. doi:10.1146/annurev-physiol-020518-114605

Zhang Y, Gross N, Li Z, Yin G, Zhong Q, Liu C, Huang Z. 2019. Upregulation of BTF3 affects the proliferation, apoptosis, and cell cycle regulation in hypopharyngeal squamous cell carcinoma. Biomedicine \& Pharmacotherapy 118:109211. doi:10.1016/j.biopha.2019.109211

ME, Garcia B, Jevnikar AM, Min W-P. 2008. Gene silencing of complement C5a 

made available under aCC-BY 4.0 International license.

Wiriyasermkul, et al. 
bioRxiv preprint doi: https://doi.org/10.1101/2020.08.10.244822; this version posted August 10, 2020. The copyright holder for this preprint (which was not certified by peer review) is the author/funder, who has granted bioRxiv a license to display the preprint in perpetuity. It is made available under aCC-BY 4.0 International license.

Wiriyasermkul, et al.

\section{Figures}

Figure 1: Wiriyasermkul, et al.

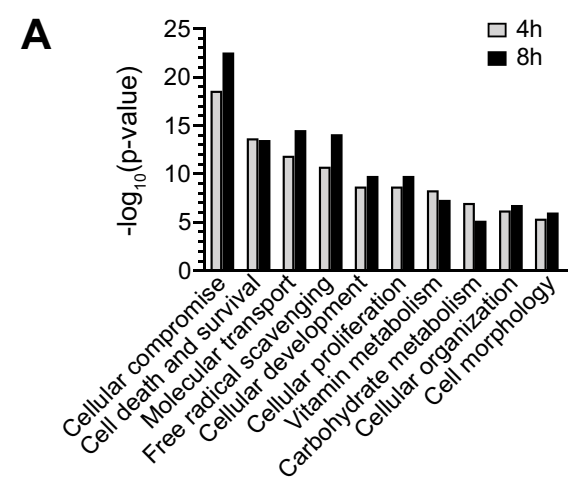

B

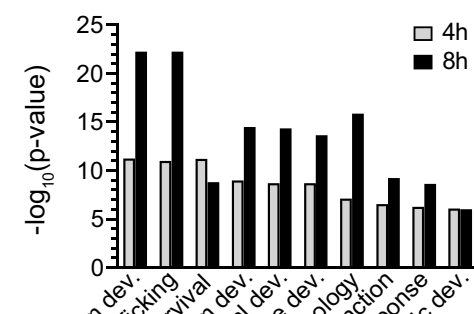

C

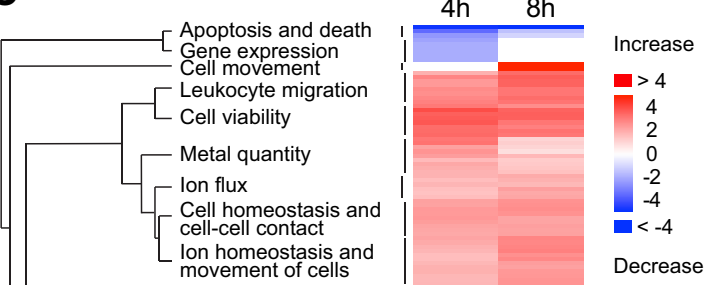

D

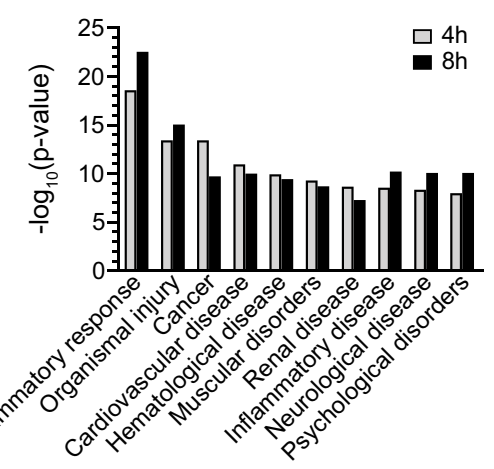

E
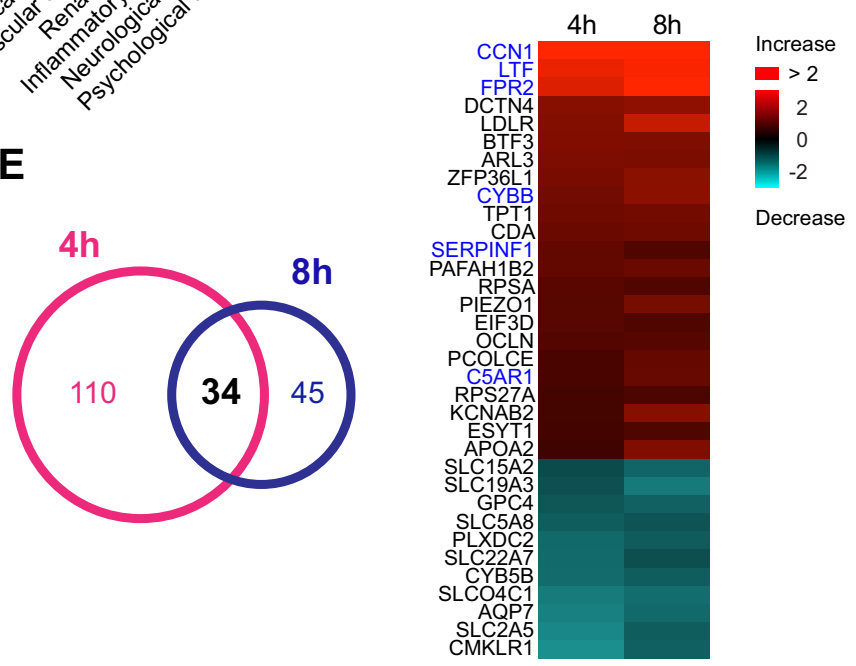
Wiriyasermkul, et al.

1123 Figure 1: Proteomics uncovers cellular functions and the relevant diseases altered in the

1124 renal IRI model

1125 Proteome of BBMVs from mouse kidneys after ischemia operation for 4 hours or 8 hours was

1126 normalized to that of sham operation. Proteins with a ratio of $4 \mathrm{~h}$ IRI/sham (4h) and $8 \mathrm{~h} \mathrm{IRI/sham}$

1127 (8h) passing 1.5-fold change and $0.05 \mathrm{p}$-value were subjected to analyze cellular functions and

1128 the relevant diseases by IPA. Top-10 cellular functions (A) and systemic functions (B) that are

1129 significantly altered in both $4 \mathrm{~h}$ and $8 \mathrm{~h}$ IRI are shown. dev. = development. C) Hierarchical

1130 heatmap of functional pathways corresponding to cellular and systemic functions in A - B.

1131 Colors indicate predicted functions. D) Top-10 diseases resulting from altered proteins. E)

1132 Area-proportional Venn diagrams (left) of biomarkers predicted by IPA. Thirty-four

1133 biomarkers found in both $4 \mathrm{~h}$ and $8 \mathrm{~h}$ are shown as a heatmap of protein expression (right).

1134 Colors indicated $\log _{2}$ fold of $4 \mathrm{~h} \mathrm{IRI} /$ sham (4h) or $8 \mathrm{~h} \mathrm{IRI/sham} \mathrm{(8h).} \mathrm{Proteins} \mathrm{highlighted} \mathrm{in}$

1135 blue are previously predicted biomarkers for IRI and/or CKD. 
bioRxiv preprint doi: https://doi org/10.1101/2020.08 10.244822 - this version posted August 10, 2020. The copyright holder for this preprint (which was not certified by peer review) is the author/funder, who has granted bioRxiv a license to display the preprint in perpetuity. It is made available under aCC-BY 4.0 International license.

Wiriyasermkul, et al.

Figure 2: Wiriyasermkul, et al.

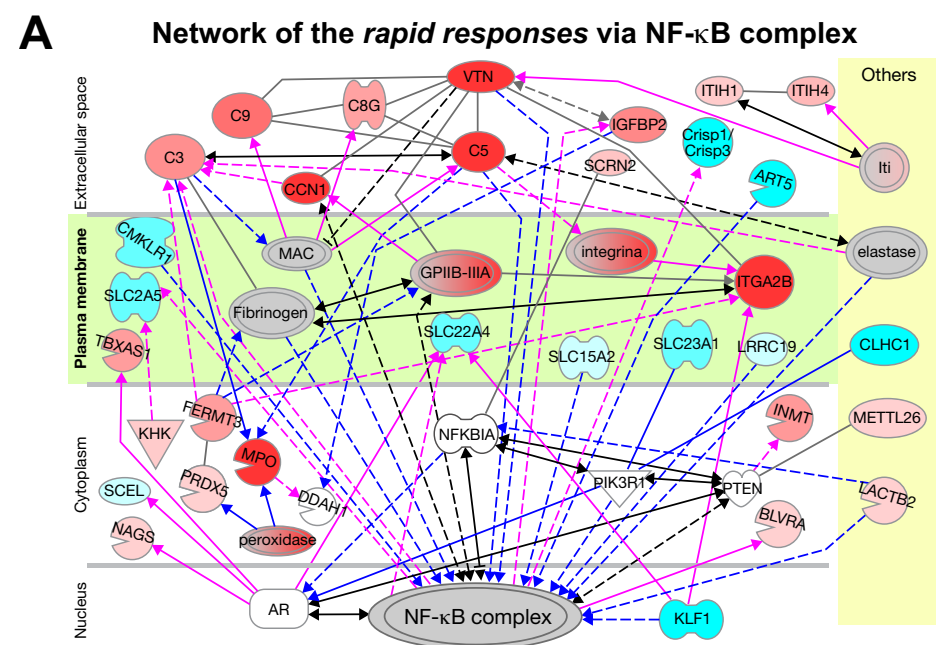

B Network of the rapid responses via MYC and PI3K complex

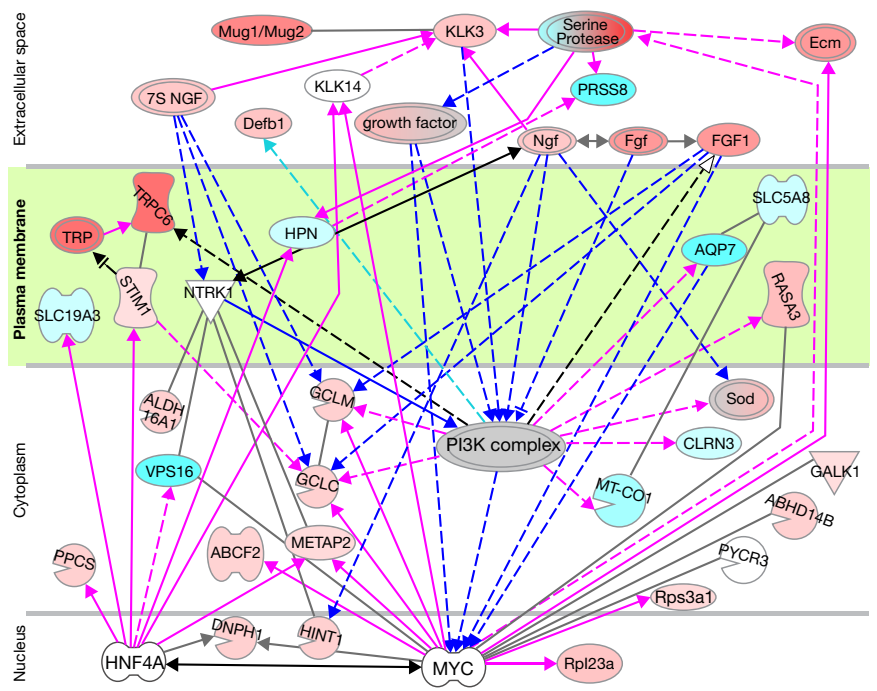

C Network of the prolonged responses via HDL and Akt

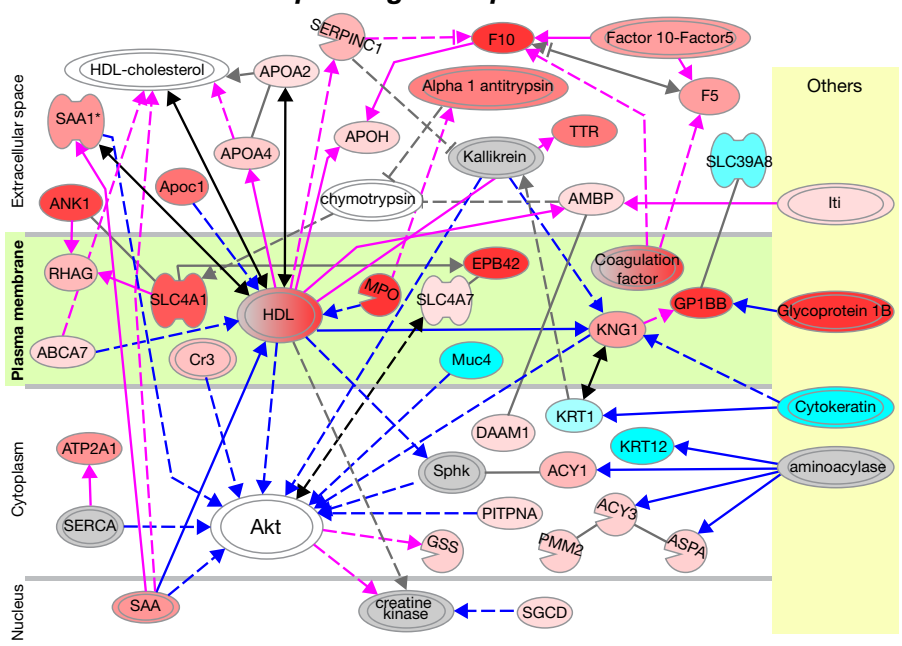

1136 Figure 2: Predicted pathways in response to $4 \mathrm{~h}$, and combination of $4 \mathrm{~h}$ and $8 \mathrm{~h}$ IRI 
1137 Identified proteins from renal BBMVs, which are significantly altered more or less than 1.5-

1138 fold change ( $\mathrm{p}$-value $<0.05)$ in $4 \mathrm{~h}$ and $8 \mathrm{~h}$ IRI, were curated into networks by IPA and literatures.

1139 Top-3 networks (A - C) with the highest scores and molecule numbers are presented. Protein

1140 expressions, that are upregulated and downregulated, are shown in red and cyan, respectively,

1141 with intensity shading corresponding to the degrees of fold change. Proteins are shaped by

1142 categories, and double cycles indicate protein complexes. Solid and dash lines represent direct

1143 and indirect interactions, respectively. Lines are colored for contrast observation in which blue

1144 and magenta lines imply activation to regulators and targeting proteins, respectively. A)

1145 Network of the rapid responses via NF- $\kappa b$ regulator at 4h IRI. Network is highly involved in

1146 innate immune system, cellular movement, and cell cycle in response to the injury, tissue

1147 disorder, and defect of molecular transport. B) Network of the rapid responses at $4 \mathrm{~h}$ IRI. The

1148 increase of several growth factors from organismal injury and abnormalities apparently

1149 regulate PI3K- and MYC-related pathways. C) Network of the prolonged responses during 4h

$1150-8 \mathrm{~h}$ IRI via HDL complex and Akt. Significant proteins at $4 \mathrm{~h}$ and $8 \mathrm{~h}$ IRI are shown. Proteins

1151 in the network are highly involved in injury-response, cell death and survival, coagulation,

1152 apolipoprotein profile, and antioxidants. 
Wiriyasermkul, et al.

Figure 3: Wiriyasermkul, et al.
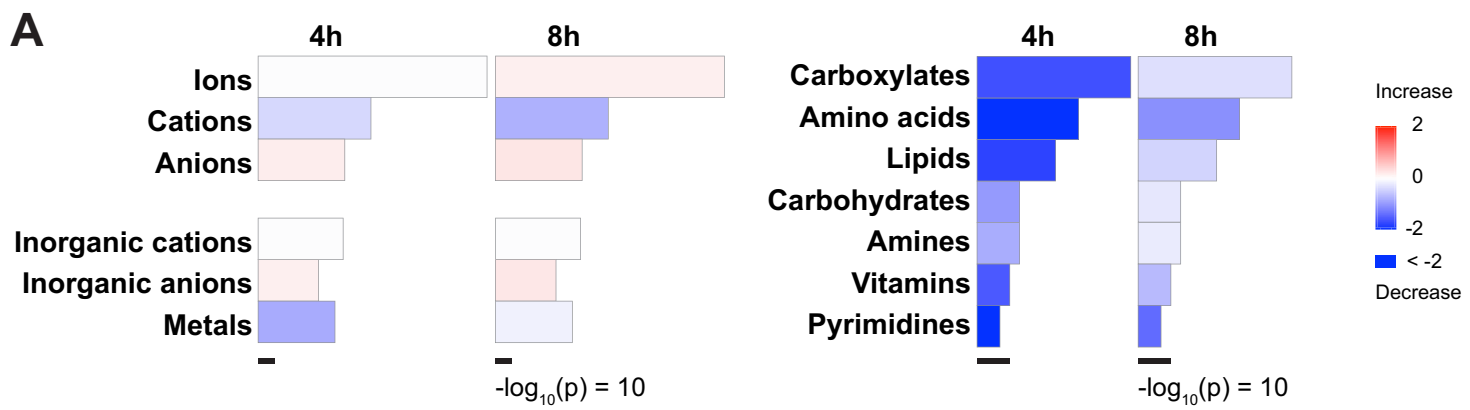

B
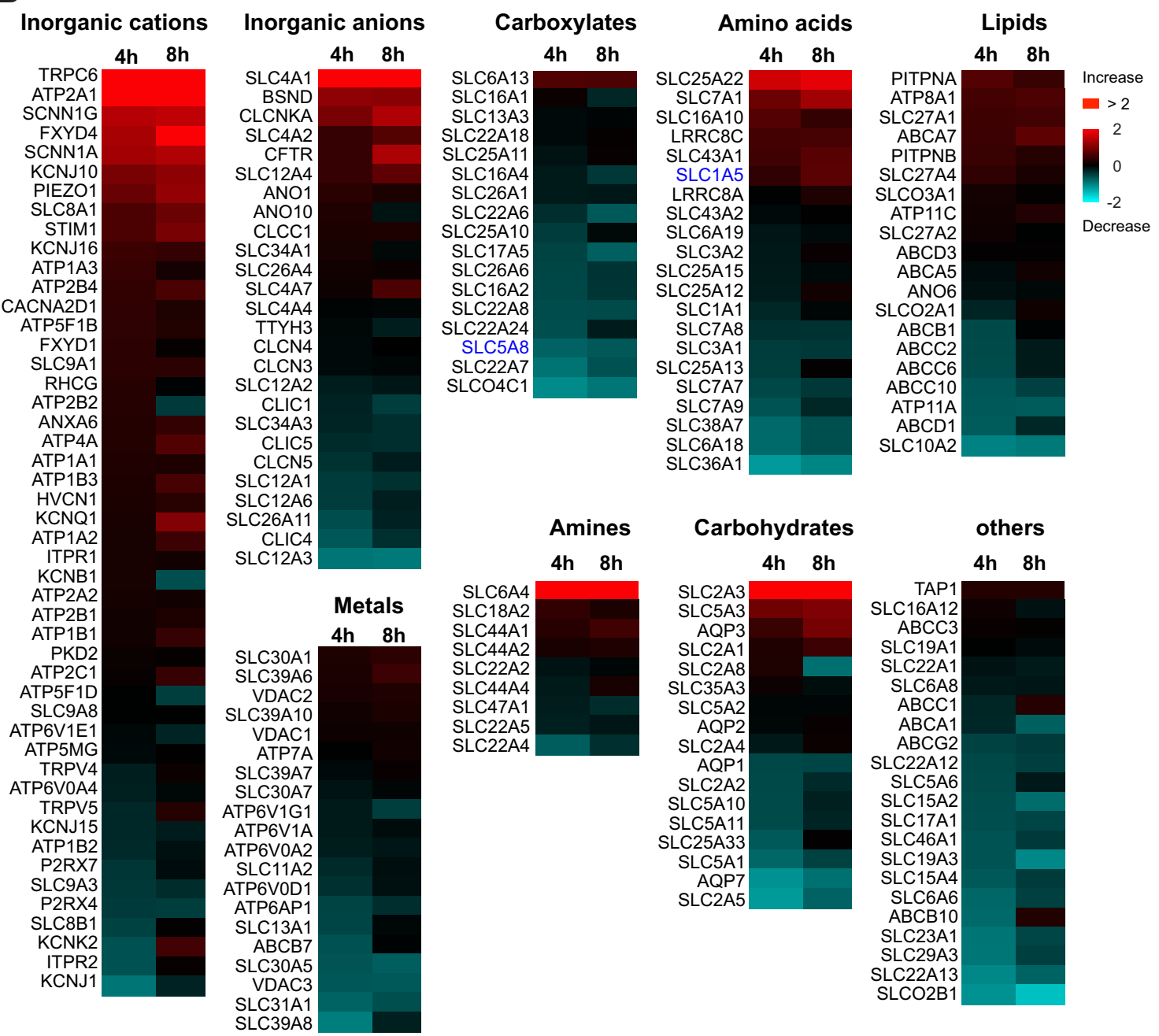

1153 Figure 3: Proteome analysis of membrane transport proteins

1154 A) Heatmap of predicted transport function analyzed from membrane transport proteins (319

1155 identified proteins). Transport function is categorized by types of substrates. Ion transport is a

1156 group of inorganic ions (lower left) and charged organic compounds (right). Transport of 
1157 organic compounds (right) comprises both charged and uncharged compounds (right). Area

1158 and colors represent $-\log _{10}(\mathrm{p}$-value) and predicted function (z-score), respectively. B) Heatmap

1159 of membrane transport proteins categorized by types of their canonical substrates. The "Others"

1160 category includes vitamin and nucleobase transporters. Colors indicate $\log _{2}$ fold of $4 \mathrm{~h} \mathrm{IRI/sham}$

1161 (4h) or 8h IRI/sham (8h). 
Figure 4: Wiriyasermkul, et al.

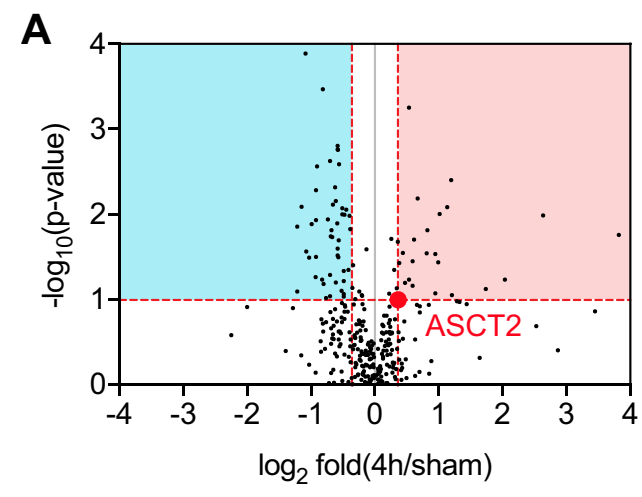

B

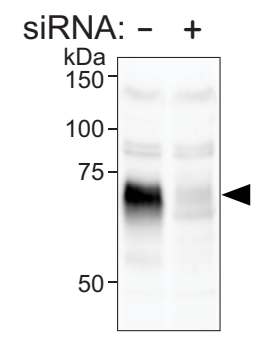

C

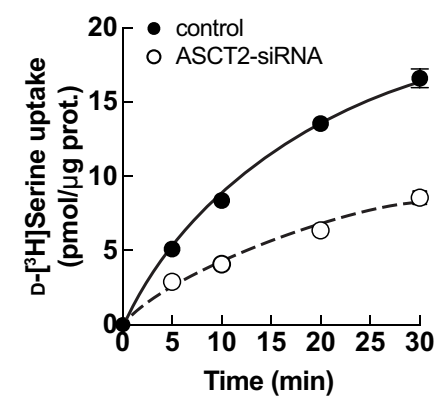

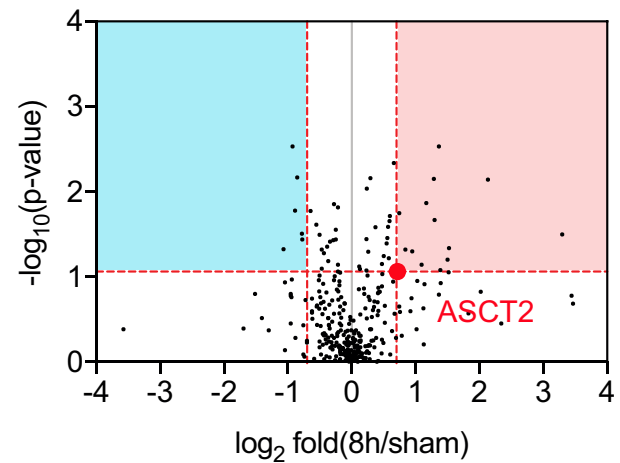

D

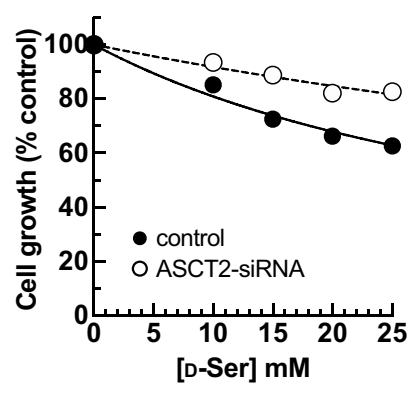

1162 Figure 4: ASCT2 is a D-serine transporter

1163 A) Volcano plots of 319 membrane transport proteins identified from the BBMV proteome of

1164 the IRI model. The $\log _{2}$ fold of $4 \mathrm{~h} \mathrm{IRI/sham} \mathrm{(left)} \mathrm{or} 8 \mathrm{~h} \mathrm{IRI/sham} \mathrm{(right)} \mathrm{were} \mathrm{plotted} \mathrm{against}$

$1165-\log _{10}$ of p-value. The value of Asct2 (red dot) was set as a cut-off value (red lines) to select

1166 candidates of D-serine transporters. Candidates with increased or decreased expression were

1167 shown in red and cyan areas, respectively. B) Western blot of ASCT2 from the membrane

1168 fraction of HEK293 transfected with ASCT2-siRNA indicated the suppression of ASCT2

1169 expression. ASCT2 was detected by using anti-hASCT2 antibody. C) Transport of $100 \mu \mathrm{M}$ D-

$1170\left[{ }^{3} \mathrm{H}\right]$ serine was measured in ASCT2-knockdown (ASCT2-siRNA) in comparison to Mock cells.

1171 Uptake was measured in PBS ( $\mathrm{Na}^{+}$-buffer). $\mathrm{n}=3$. D) Cell-growth measurement (XTT assay)

1172 of HEK293 cells treated with D-serine. Prior to treatment, the cells were transfected with

1173 ASCT2-siRNA or without siRNA (control). After transfection, the cells were treated with D- 

made available under aCC-BY 4.0 International license.

Wiriyasermkul, et al.

1174 serine at the indicated concentration for two days. Data represent percent cell growth compared

1175 to the non-treated cells. The graphs were fitted to inhibition kinetics (Dose-response -

1176 Inhibition). $\mathrm{n}=5$. 
Wiriyasermkul, et al.

Figure 5: Wiriyasermkul, et al.

A

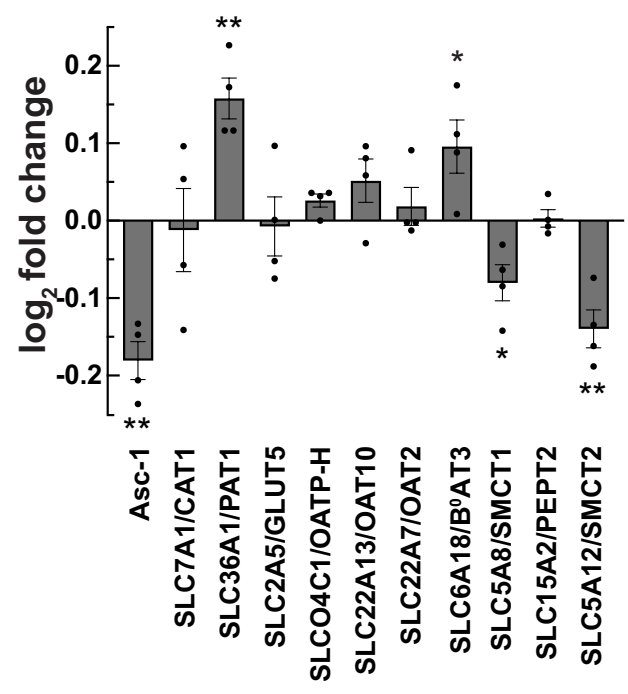

B

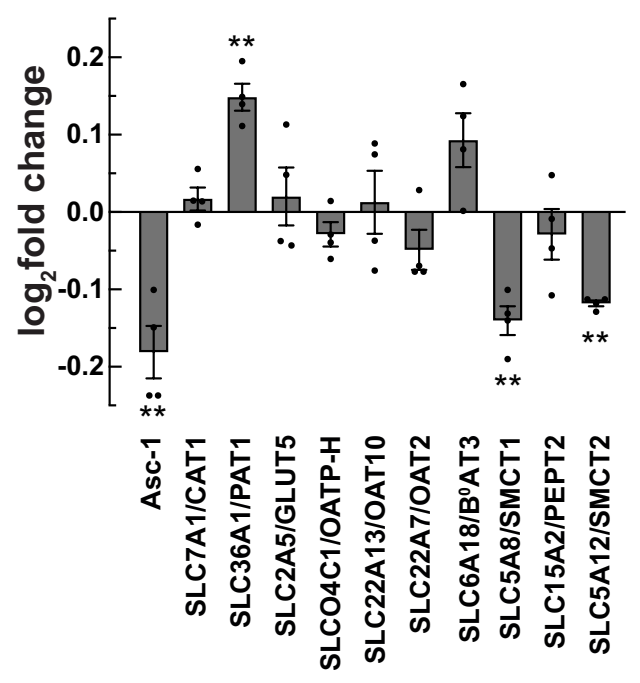

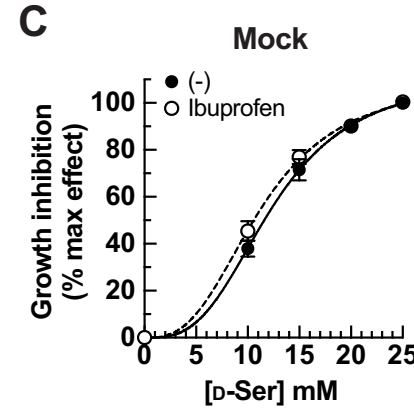

[D-Ser] mM

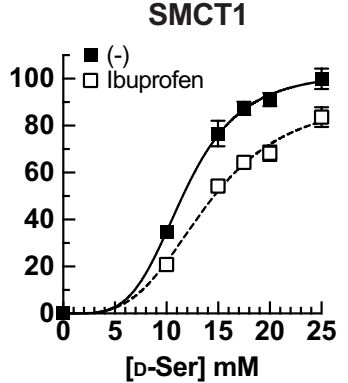

[D-Ser] mM

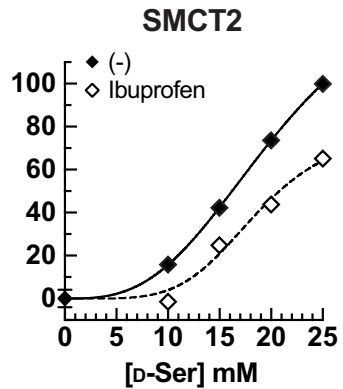

Figure 5: Identification of SMCTs as candidates of D-serine transporters

1178 Candidates of D-serine transporters were screened by cell growth determination. HEK293 cells

1179 were transfected with various cDNA clones, as indicated. After transfection, the cells were

1180 treated with either $15 \mathrm{mM}$ (A) or $25 \mathrm{mM}$ (B) D-serine for two days and cell growth was

1181 examined by XTT assay. The growth effect by D-serine treatment in both transfected cells and

1182 Mock was normalized with that of no treatment. Subsequently, the normalized growth of the

1183 transfected cells was calculated as "fold change" compared to that of Mock at the same D-

1184 serine concentration and plotted as $\log _{2}$ fold change. The order of clones was rearranged

1185 according to Table $\left.1 .{ }^{*} p<0.05 ;{ }^{*} p<0.01 ; \mathrm{n}=4 . \mathrm{C}\right)$. Inhibition effect of ibuprofen on D- 
1186 serine-induced cell growth. FlpInTR-SMCT1 (SMCT1), FlpInTR-SMCT2 (SMCT2) and

1187 FlpInTR-Mock (Mock) cells were preincubated with $0.5 \mathrm{mM}$ ibuprofen prior to treated with

1188 D-serine at indicated concentration for 2 days. Cell growth was measured by XTT assay. For

1189 comparison, the maximum growth inhibition by $25 \mathrm{mM}$ D-serine treatment was set as $100 \%$

1190 inhibition and no D-serine treatment was set as $0 \%$ inhibition. The graphs were fitted to

1191 inhibition kinetics (Dose-response - Inhibition). $\mathrm{n}=5$. 


\section{Figure 6: Wiriyasermkul, et al.}
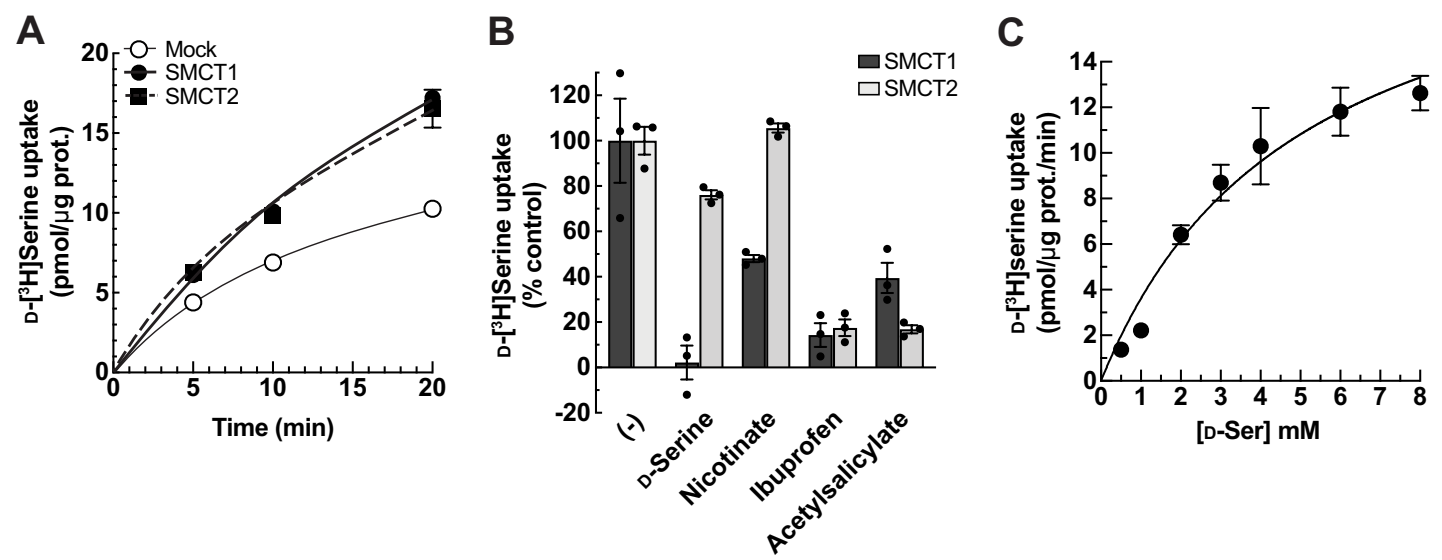

1192 Figure 6: Characterization of SMCT1 and SMCT2 as D-serine transporters using

\section{$1193 \quad$ SMCTs-stably expressing cell lines}

1194 A) Time course of $100 \mu \mathrm{M}$ D- $\left[{ }^{3} \mathrm{H}\right]$ serine uptake in FlpInTR-SMCT1 (SMCT1), FlpInTR-

1195 SMCT2 (SMCT2) and Mock cells with ASCT2 knockdown. Prior to measure D-[3H]serine

1196 transport, the cells were transfected with ASCT2-siRNA for two days. $n=4$. B) Inhibition of

$119720 \mu \mathrm{M}$ D- $\left[{ }^{3} \mathrm{H}\right]$ serine uptake by several inhibitors. Transport of D- $\left[{ }^{3} \mathrm{H}\right]$ serine by ASCT2-siRNA

1198 transfected FlpInTR stable cell lines were measured in the absence (-) or presence of $5 \mathrm{mM}$

1199 inhibitors as indicated. Uptake was incubated for $10 \mathrm{~min}$. Graphs represented the uptake data

1200 subtracted with those of Mock cells. $n=3$. C) Concentration dependence of D- $\left[{ }^{3} \mathrm{H}\right]$ serine transport in FlpInTR-SMCT1 cells. The cells were transfected with ASCT2-siRNA and cultured for two days prior to measuring the transport. Uptake of ${ }^{D}-\left[{ }^{3} \mathrm{H}\right]$ serine $(0.5-8 \mathrm{mM})$

1203 was measured for $10 \mathrm{~min}$ in PBS. The graph represented D- $\left[{ }^{3} \mathrm{H}\right]$ serine transport in FlpInTR-

1204 SMCT1 subtracted with those of Mock cells. The uptake values were fitted to Michaelis-

Menten plot, with apparent $\mathrm{K}_{\mathrm{m}}$ of $5.0 \mathrm{mM}$ and $\mathrm{V}_{\max }$ of $21.6 \mathrm{pmol} / \mu \mathrm{g}$ protein $/ \mathrm{min} . \mathrm{n}=3-4$. 
Figure 7: Wiriyasermkul, et al.
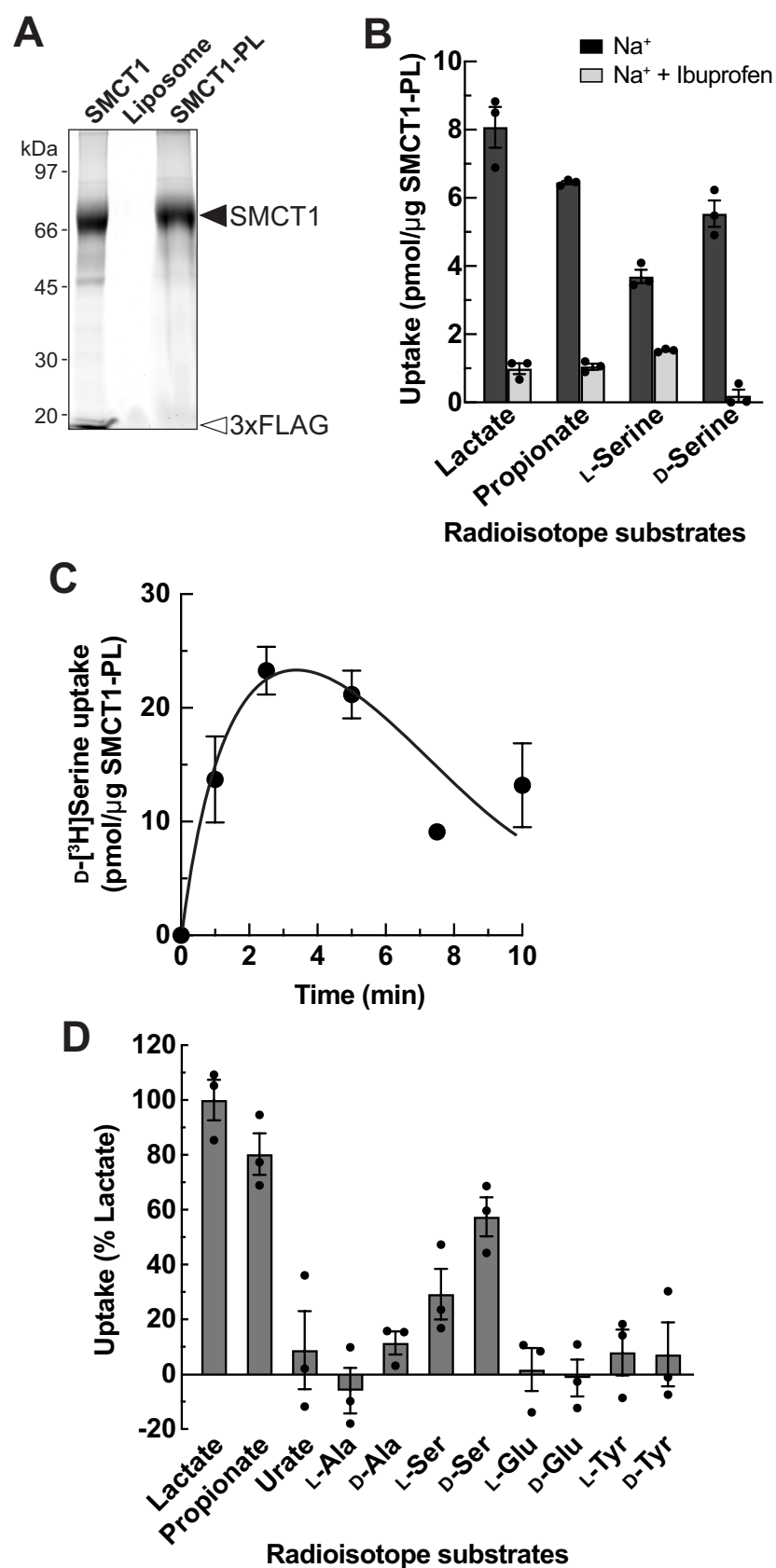

1206 Figure 7: Characterization of SMCT1 as a D-serine transporter using SMCT1-

\section{7 reconstituted proteoliposomes}

A) Stain-free SDS-PAGE gel (Bio-Rad) shows SMCT1 (SMCT1) purified from

1209 pCMV14-SMCT1-transfected Expi293F cells, reconstituted empty liposomes (Liposome) and

1210 SMCT1 proteoliposomes (SMCT1-PL). Closed arrowhead indicates SMCT1, whereas opened 
1211 arrowhead indicates 3xFLAG peptides, which were used to elute the purified SMCT1. B)

1212 Ibuprofen effect on the uptake of $\left[{ }^{3} \mathrm{H}\right]$ lactate, $\left[{ }^{3} \mathrm{H}\right]$ propionate, $\mathrm{L}-\left[{ }^{3} \mathrm{H}\right]$ serine, and $\mathrm{D}-\left[{ }^{3} \mathrm{H}\right]$ serine in

1213 SMCT1 proteoliposomes (SMCT1-PL). Uptakes of $50 \mu \mathrm{M}$ radiolabeled substrates were

1214 measured in the presence or absence of $1 \mathrm{mM}$ ibuprofen for $5 \mathrm{~min}$. The graphs represent uptake

1215 values in $\mathrm{Na}^{+}$- buffer $\left(\mathrm{Na}^{+}\right)$, which were subtracted with those in $\mathrm{Na}^{+}$-free buffer. $\mathrm{n}=3$. C)

1216 Time course of D- $\left[{ }^{3} \mathrm{H}\right]$ serine transport in SMCT1 proteoliposomes. D- $\left[{ }^{3} \mathrm{H}\right]$ Serine transport $(200$

$1217 \mu \mathrm{M})$ was measured in the SMCT1 proteoliposomes in $\mathrm{Na}^{+}$-buffer. All uptake values were

1218 subtracted with the uptake in $\mathrm{Na}^{+}$-free buffer. $\mathrm{n}=3$. D) Substrate selectivity of SMCT1-PL.

1219 The uptakes of $50 \mu \mathrm{M}$ radiolabeled substrates were measured in SMCT1 proteoliposomes for

$12205 \mathrm{~min}$. The uptake of each substrate in $\mathrm{Na}^{+}$- buffer was subtracted with those in $\mathrm{Na}^{+}$-free buffer,

1221 and calculated as \% lactate uptake. Bar graphs represent mean \pm standard error from 3

1222 independent experiments. $\mathrm{n}=2-4$ in each experiment. 

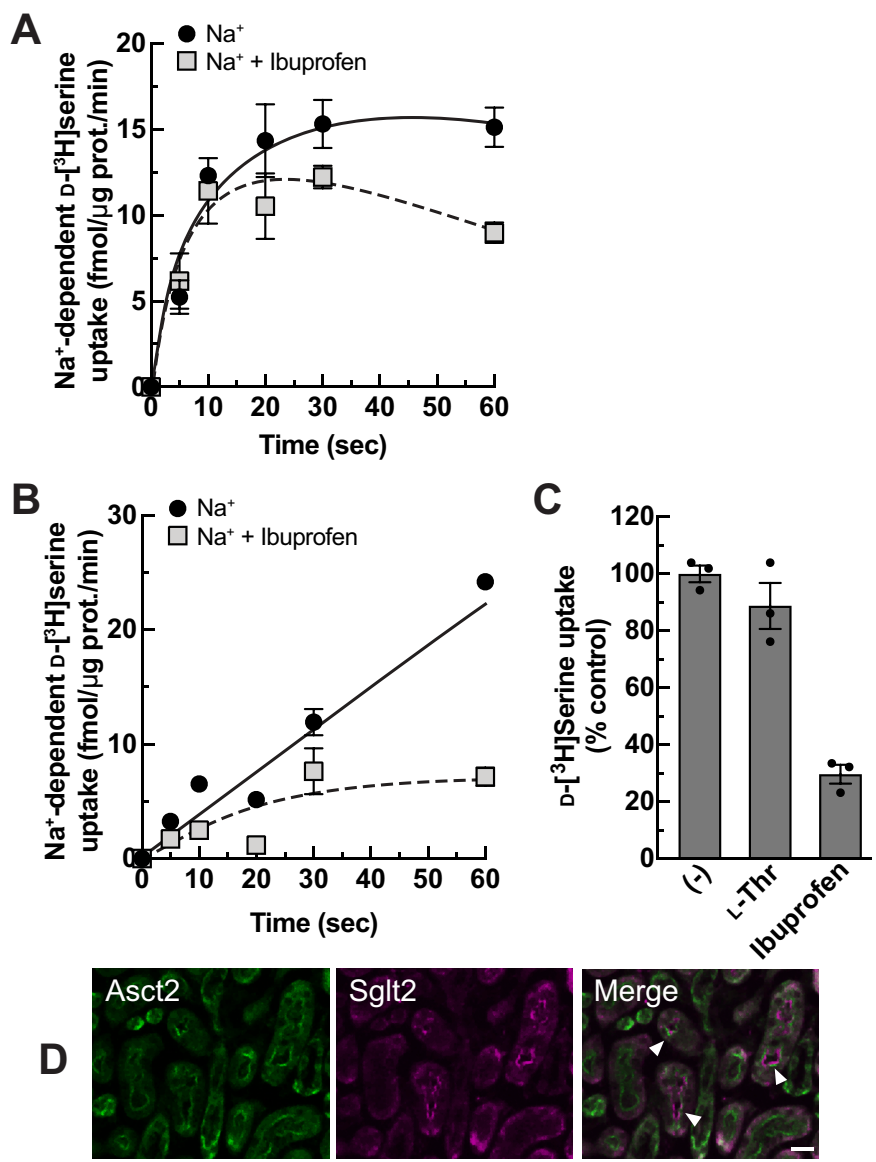

E
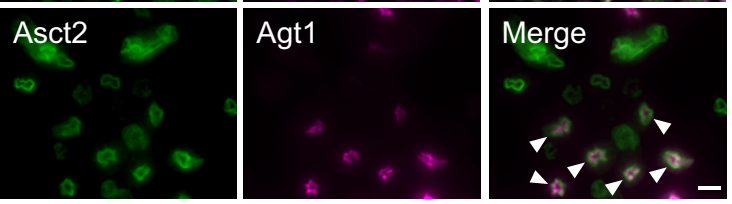

$\mathbf{F}$
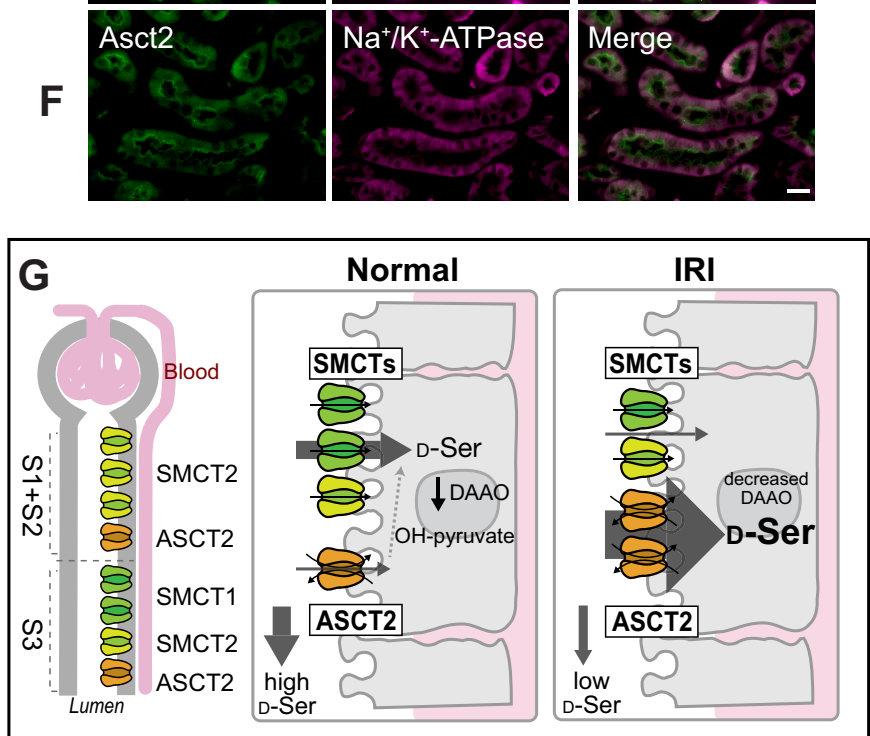

1223 Figure 8: Characterization of D-serine transport at the apical membrane of renal 
1225 A) D- $\left[{ }^{3} \mathrm{H}\right]$ Serine transport in BBMVs preloaded with $4 \mathrm{mM}$ L-glutamine. Time courses of 10

$1226 \mu \mathrm{M} \mathrm{D}-\left[{ }^{3} \mathrm{H}\right]$ serine transport in L-glutamine-preloaded BBMVs were measured in the presence 1227 or absence of $1 \mathrm{mM}$ ibuprofen. The graphs represented uptake data in $\mathrm{Na}^{+}$-buffer $\left(\mathrm{Na}^{+}\right)$ 1228 subtracted with those in $\mathrm{Na}^{+}$-free buffer. $\mathrm{n}=3-4$. B) $\mathrm{D}-\left[{ }^{3} \mathrm{H}\right]$ Serine transport in BBMVs 1229 without amino acid preloading. Transports of $\mathrm{D}-\left[{ }^{3} \mathrm{H}\right]$ serine were measured in a similar way to

1230 A) but the experiment was carried out in BBMVs without any amino acid preloading. $\mathrm{n}=3-$

1231 4. C) Inhibition of $\mathrm{D}_{-}\left[{ }^{3} \mathrm{H}\right]$ serine transport in BBMVs. Uptake of $10 \mu \mathrm{M} \mathrm{D}-\left[{ }^{3} \mathrm{H}\right]$ serine was 1232 measured in the presence or absence of $1 \mathrm{mM}$ inhibitors for $1 \mathrm{~min} . \mathrm{n}=3$. D - F) Localization 1233 of Asct2 in mouse kidney by immunofluorescent staining. Mouse kidney slide was co-stained 1234 with anti-mAsct2(NT) antibody (Asct2; green) and protein markers for renal proximal tubule 1235 segments: anti-Sglt2 antibody (D: Sglt2, apical membrane marker of S1 - S2 segment), anti1236 Agt1 antibody (E: Agt1, apical membrane marker of S3 segment), and anti- $\mathrm{Na}^{+} / \mathrm{K}^{+}$-ATPase 1237 antibody $\left(\mathrm{F}: \mathrm{Na}^{+} / \mathrm{K}^{+}\right.$-ATPase, basolateral membrane marker). Merge image is shown in the 1238 right pictures with DAPI (blue) staining. Scale bar $=20 \mu \mathrm{m}$. G) Schematic model of ASCT2 1239 and SMCTs in D-serine transport at different segments of proximal tubules. In physiological 1240 conditions, ASCT2 expression is less while SMCTs are abundant, suggesting that SMCTs 1241 mainly contribute to D-serine transport. In the IRI where SMCTs are reduced but ASCT2 is 1242 increased, a high affinity of D-serine transport reduces luminal D-serine. 
1243 Table 1. Protein candidates for diagnosis of ischemia-reperfusion kidney injury

\begin{tabular}{|c|c|c|c|c|c|c|c|c|}
\hline Protein & Name & Localization & Function/Roles & Application in kidney diseases ${ }^{\mathrm{a}}$ & Application in others ${ }^{a}$ & $\begin{array}{c}4 \mathrm{~h} / \\
\text { sham }\end{array}$ & $\begin{array}{c}\text { 8h/ } \\
\text { shamam }\end{array}$ & References \\
\hline \multicolumn{9}{|c|}{ Protein biomarkers previously predicted in kidney diseases } \\
\hline $\begin{array}{c}\text { CCN1 } \\
\text { (CYR61) }\end{array}$ & $\begin{array}{l}\text { IGF binding } \\
\text { protein } 10\end{array}$ & $\begin{array}{l}\text { Extracellular: } \\
\text { ECM protein }\end{array}$ & $\begin{array}{l}\text { Promotes chemotaxis, angiogenesis, cell adhesion, } \\
\text { and tissue repair. }\end{array}$ & $\begin{array}{l}\text { Diagnosis of IRI, renal injury, } \\
\text { CKD }\end{array}$ & Tissue repair & 41.4 & 29.9 & Marx et al., 2018 \\
\hline LTF & Lactotransferrin & $\begin{array}{l}\text { Extracellular: } \\
\text { Enzyme }\end{array}$ & $\begin{array}{l}\text { Multifunctional secreted protein involved in immune } \\
\text { response to infection and injury. }\end{array}$ & $\begin{array}{l}\text { High RNA expression in AKI } \\
\text { transplantation }\end{array}$ & $\begin{array}{l}\text { Immunotherapy, anti- } \\
\text { inflammation }\end{array}$ & 6.5 & 7.7 & $\begin{array}{l}\text { Famulski et al., 2013; } \\
\text { Kruzel et al., 2017 }\end{array}$ \\
\hline $\begin{array}{l}\text { FPR2 } \\
(\mathbf{A L X})\end{array}$ & $\begin{array}{l}\text { Formyl peptide } \\
\text { receptor } 2\end{array}$ & $\begin{array}{l}\text { PM: } \\
\text { GPCR }\end{array}$ & $\begin{array}{l}\text { Receptor of neutrophil chemotactic factors which } \\
\text { promotes neutrophil activation. }\end{array}$ & $\begin{array}{l}\text { Target of diabetic nephropathy } \\
\text { treatment }\end{array}$ & $\begin{array}{l}\text { Treatment of wound } \\
\text { repair, Influenza }\end{array}$ & 5.7 & 9.1 & Luan et al., 2020 \\
\hline $\begin{array}{c}\text { CYBB } \\
\text { (NOX2) }\end{array}$ & $\begin{array}{l}\text { Cytochrome B- } \\
245 \beta \text {-chain }\end{array}$ & $\begin{array}{l}\text { PM: } \\
\text { Enzyme }\end{array}$ & $\begin{array}{l}\text { Generates superoxide in phagocytes and emerge } \\
\text { inflammation. Acts as a modulator of IRI and } \\
\text { fibrogenesis. }\end{array}$ & Target of IRI treatment & $\begin{array}{l}\text { Target for treatment of } \\
\text { immunodeficiency } \\
\text { diseases }\end{array}$ & 2.2 & 2.7 & $\begin{array}{l}\text { Djamali et al., } 2008 \text {; } \\
\text { Karim et al., } 2015\end{array}$ \\
\hline SERPINF1 & $\begin{array}{l}\text { Serpin family F } \\
\text { member } 1\end{array}$ & $\begin{array}{l}\text { Extracellular: } \\
\text { Others }\end{array}$ & $\begin{array}{l}\text { Neurotrophic protein inducing retinoblastoma cell } \\
\text { differentiation. }\end{array}$ & $\begin{array}{l}\text { Prognosis of acute rejection, } \\
\text { CKD }\end{array}$ & & 1.9 & 1.7 & $\begin{array}{l}\text { Lu et al., 2016; } \\
\text { Makridakis et al., } 2020\end{array}$ \\
\hline C5AR1 & $\begin{array}{l}\text { Complement C5a } \\
\text { receptor } 1\end{array}$ & $\begin{array}{l}\text { aPM: } \\
\text { GPCR }\end{array}$ & $\begin{array}{l}\text { Activates chemotaxis and superoxide production. } \\
\text { Promote inflammation and injury. }\end{array}$ & $\begin{array}{l}\text { Indicator and treatment target of } \\
\text { renal injury, fibrosis }\end{array}$ & $\begin{array}{l}\text { Pathogenesis of } \\
\text { inflammatory diseases }\end{array}$ & 1.6 & 2.0 & $\begin{array}{l}\text { Tang et al., 2018; } \\
\text { Zheng et al., } 2008 \\
\end{array}$ \\
\hline \multicolumn{9}{|c|}{ Protein biomarkers newly predicted in this study } \\
\hline DCTN4 & $\begin{array}{l}\text { Dynactin } \\
\text { subunit } 4\end{array}$ & Nucleus & Component of dynein-dynactin complex. & $\begin{array}{l}\text { [DCTN4 mutation associated } \\
\text { with infection in Citric Fibrosis] }\end{array}$ & - & 2.6 & 2.8 & Emond et al., 2012 \\
\hline LDLR & LDL receptor & $\begin{array}{l}\text { PM: } \\
\text { Carriers }\end{array}$ & $\begin{array}{l}\text { Rate-limiting step for cholesterol synthesis. } \\
\text { Modulated by PCSK } 9\end{array}$ & $\begin{array}{l}\text { [PCSK9 is a diagnostic marker } \\
\text { for nephrotic syndrome] }\end{array}$ & $\begin{array}{l}\text { Treatment of } \\
\text { dyslipidemia }\end{array}$ & 2.5 & 4.6 & $\begin{array}{l}\text { Shen et al., 2020; } \\
\text { Shrestha et al., } 2019\end{array}$ \\
\hline BTF3 & Basic TF 3 & $\begin{array}{l}\text { Nucleus: } \\
\text { Regulator }\end{array}$ & $\begin{array}{l}\text { General transcription factor forming a complex with } \\
\text { RNA polymerase II }\end{array}$ & - & $\begin{array}{l}\text { [Associated with } \\
\text { several cancer types] }\end{array}$ & 2.4 & 2.42 & Zhang et al., 2019 \\
\hline ARL3 & $\begin{array}{l}\text { ADP ribosylation } \\
\text { factor-like } 3\end{array}$ & $\begin{array}{l}\text { Cytoplasm: } \\
\text { Enzyme }\end{array}$ & $\begin{array}{l}\text { Small GTP-binding protein essential for cilia } \\
\text { biogenesis and cytokinesis. }\end{array}$ & $\begin{array}{l}\text { [ARL3 involve in kidney } \\
\text { development] }\end{array}$ & & 2.4 & 2.3 & Schrick et al., 2006 \\
\hline $\begin{array}{l}\text { ZFP36L1 } \\
\text { (BRF1) }\end{array}$ & ZFP36-like 1 & $\begin{array}{l}\text { Nucleus: } \\
\text { Regulator }\end{array}$ & $\begin{array}{l}\text { RNA-BP that promotes ARE-mediated RNA decay. } \\
\text { Mediate HIF1a degradation. }\end{array}$ & - & Tumor suppressor & 2.3 & 2.7 & Sanduja et al., 2011 \\
\hline TPT1 & Fortilin & Cytoplasm & $\begin{array}{l}\text { Promote cell growth and regeneration, and host } \\
\text { defense mechanism }\end{array}$ & - & $\begin{array}{l}\text { Marker for cell } \\
\text { viability }\end{array}$ & 2.1 & 2.2 & $\begin{array}{l}\text { Pinkaew and Fujise, } \\
2017\end{array}$ \\
\hline CDA & $\begin{array}{l}\text { Cytidine } \\
\text { deaminase }\end{array}$ & $\begin{array}{l}\text { Cytoplasm: } \\
\text { Enzyme }\end{array}$ & $\begin{array}{l}\text { Deaminate cytidine to uridine. Highly express in } \\
\text { leukocyte and enable TLR } 8 \text { response. }\end{array}$ & - & $\begin{array}{l}\text { [Associated with TLR8 } \\
\text { function] }\end{array}$ & 2.0 & 2.11 & Furusho et al., 2019 \\
\hline PAFAH1B2 & $\begin{array}{l}\text { PAF-AH } \\
\text { subunit } \beta\end{array}$ & $\begin{array}{l}\text { Cytoplasm: } \\
\text { Enzyme }\end{array}$ & $\begin{array}{l}\text { A HIF } \alpha \text { targeting gene involved in development, } \\
\text { inflammation, cancer. }\end{array}$ & - & $\begin{array}{l}\text { [Target of cancer } \\
\text { treatment] }\end{array}$ & 1.9 & 2.0 & Ma et al., 2018 \\
\hline RPSA & $\begin{array}{l}\text { Ribosomal } \\
\text { protein SA }\end{array}$ & $\begin{array}{l}\text { Cytoplasm: } \\
\text { Regulator }\end{array}$ & $\begin{array}{l}\text { Component of } 40 \mathrm{~S} \text { ribosome. Functions as laminin } \\
\text { receptor for cell adhesion }\end{array}$ & & $\begin{array}{l}\text { Target of cancer } \\
\text { therapy }\end{array}$ & 1.8 & 1.7 & $\begin{array}{l}\text { DiGiacomo and } \\
\text { Meruelo, } 2016\end{array}$ \\
\hline PIEZO1 & $\begin{array}{l}\text { Piezo-type } \\
\text { mechanosensitive } \\
\text { ion channel } 1\end{array}$ & $\begin{array}{l}\text { Cytoplasm: } \\
\text { Ion channel }\end{array}$ & $\begin{array}{l}\text { Mechano-sensing cation channel activated for } \\
\text { vascular remodeling and development. }\end{array}$ & $\begin{array}{l}\text { [Control intraluminal pressure } \\
\text { and urine flow] }\end{array}$ & Mechano-stress sensor & 1.8 & 2.2 & Martins et al., 2016 \\
\hline EIF3D & eIF3 subunit D & $\begin{array}{l}\text { Cytoplasm: } \\
\text { Regulator }\end{array}$ & $\begin{array}{l}\text { Component of eIF3 specifically initiates mRNA } \\
\text { involved in cell proliferation }\end{array}$ & & $\begin{array}{l}\text { [Highly detected in } \\
\text { cancers] }\end{array}$ & 1.8 & 1.7 & Yin et al., 2018 \\
\hline OCLN & Occludin & $\begin{array}{l}\text { PM: Tight } \\
\text { junction }\end{array}$ & $\begin{array}{l}\text { A tight junction protein, a substrate of MMP9. } \\
\text { Associates with metastasis, inflammation, and repair }\end{array}$ & $\begin{array}{l}\text { Loss and repair in tight junction } \\
\text { membranes during IRI }\end{array}$ & - & 1.7 & 1.7 & Lee et al., 2011 \\
\hline
\end{tabular}


1244 Table 1 (continued). Protein candidates for diagnosis of ischemia-reperfusion kidney injury

\begin{tabular}{|c|c|c|c|c|c|c|c|c|}
\hline Protein & Name & Localization & Function/Roles & \multicolumn{4}{|c|}{ 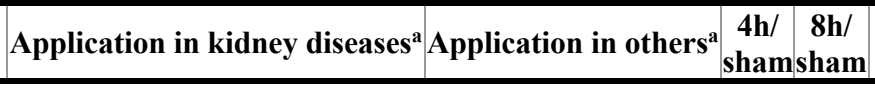 } & Refs \\
\hline \multicolumn{9}{|c|}{ Protein biomarkers newly predicted in this study } \\
\hline PCOLCE & $\begin{array}{l}\text { Procollagen C- } \\
\text { endopeptidase } \\
\text { enhancer }\end{array}$ & $\begin{array}{l}\text { Extracellular: } \\
\text { Others }\end{array}$ & $\begin{array}{l}\text { Binds to procollagen and enhances procollagen C- } \\
\text { proteinase activity. }\end{array}$ & highly detected in CKD & $\begin{array}{l}\text { [Highly detected in } \\
\text { liver fibrosis] }\end{array}$ & 1.6 & 2.0 & Özkan et al., 2019 \\
\hline RPS27A & $\begin{array}{l}\text { Ribosomal } \\
\text { protein } \mathrm{S} 27 \mathrm{a}\end{array}$ & Cytoplasm & Component of Ubiquitin and 40S ribosome & $\begin{array}{l}\text { [Target of MSC for diabetic } \\
\text { nephropathy] }\end{array}$ & $\begin{array}{l}\text { [Highly detected in } \\
\text { cancers] }\end{array}$ & 1.5 & 1.6 & Yang et al., 2018 \\
\hline KCNAB2 & $\begin{array}{l}\mathrm{K}^{+} \text {channel } \\
\text { subunit } \beta-2\end{array}$ & $\begin{array}{l}\text { PM: } \\
\text { Ion channel }\end{array}$ & $\begin{array}{l}\mathrm{K}^{+} \text {channel regulating nerve signaling. KCNAB2 } \\
\text { inhibition attenuates brain hypoxia. }\end{array}$ & (1) & $\begin{array}{l}\text { Target for treatment of } \\
\text { brain hypoxia }\end{array}$ & 1.5 & 2.6 & Wei et al., 2003 \\
\hline ESYT1 & $\begin{array}{l}\text { Extended } \\
\text { synaptotagmin } 1\end{array}$ & $\begin{array}{l}\text { Cytoplasm: } \\
\text { Adaptor }\end{array}$ & $\begin{array}{l}\text { Transports lipid between adjacent membranes or } \\
\text { exocytosis to compensate for plasma membrane lipid } \\
\text { change. }\end{array}$ & - & - & 1.5 & 1.6 & Saheki et al., 2016 \\
\hline APOA2 & $\begin{array}{l}\text { Apolipoprotein } \\
\text { A2 }\end{array}$ & $\begin{array}{l}\text { Extracellular: } \\
\text { Transporter }\end{array}$ & $\begin{array}{l}\text { Component of HDL. Transports oxidized } \\
\text { phospholipids in anti-inflammation. }\end{array}$ & Altered in kidney diseases & $\begin{array}{l}\text { Prognosis of cancer } \\
\text { progression }\end{array}$ & 1.5 & 2.4 & $\begin{array}{l}\text { Kovacevic et al., 2017; } \\
\text { Vaziri, } 2016\end{array}$ \\
\hline SLC15A2 & $\begin{array}{l}\text { Peptide } \\
\text { transporter } 2\end{array}$ & $\begin{array}{l}\text { PM: } \\
\text { Transporter }\end{array}$ & Peptide and drug transporter in proximal tubule cells. & $\begin{array}{l}\text { [Participate in drug delivery and } \\
\text { accumulation of toxicants] }\end{array}$ & 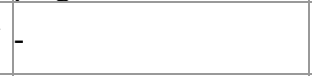 & 0.7 & 0.6 & Kamal et al., 2008 \\
\hline SLC19A3 & $\begin{array}{l}\text { Thiamine } \\
\text { transporter } 2\end{array}$ & $\begin{array}{l}\text { PM: } \\
\text { Transporter }\end{array}$ & $\begin{array}{l}\text { Reuptakes Thiamine. Malfunction of THTR2 } \\
\text { associated with thiamine deficiency. }\end{array}$ & $\begin{array}{l}\text { [Glucose in diabetes and CKD } \\
\text { reduces THTR2 expression] }\end{array}$ & - & 0.6 & 0.5 & Bukhari et al., 2011 \\
\hline GPC4 & Glypican 4 & $\begin{array}{l}\text { PM: } \\
\text { Receptor }\end{array}$ & $\begin{array}{l}\text { Heparan sulfate proteoglycan that modulates HGF } \\
\text { signal to renal tubule formation }\end{array}$ & $\begin{array}{l}\text { [important for renal tubule } \\
\text { formation] }\end{array}$ & [Tumor suppressor] & 0.6 & 0.6 & Karihaloo et al., 2004 \\
\hline SLC5A8 & $\begin{array}{l}\mathrm{Na}^{+} / \text {mono- } \\
\text { carboxylate } \\
\text { transporter 1 }\end{array}$ & $\begin{array}{l}\text { PM: } \\
\text { Transporter }\end{array}$ & $\begin{array}{l}\text { Transports lactate, pyruvate, butyrate, and short chain } \\
\text { fatty acids. Target of NSAIDs. }\end{array}$ & $\begin{array}{l}\text { [Lactate is prognosis marker of } \\
\text { inflammation] }\end{array}$ & Tumor suppressor & 0.6 & 0.6 & Ganapathy et al., 2008 \\
\hline $\begin{array}{l}\text { PLXDC2 } \\
\text { (TEM7R) }\end{array}$ & $\begin{array}{l}\text { Plexin domain } \\
\text { containing } 2\end{array}$ & $\begin{array}{l}\text { PM: } \\
\text { Receptor }\end{array}$ & Receptor of pigment epithelium derived factor. & - & $\begin{array}{l}\text { [Expressed in Ischemic } \\
\text { stroke] }\end{array}$ & 0.5 & 0.6 & Cheng et al., 2014 \\
\hline SLC22A7 & $\begin{array}{l}\text { Organic anion } \\
\text { transporter } 2\end{array}$ & $\begin{array}{l}\text { PM: } \\
\text { Transporter }\end{array}$ & $\begin{array}{l}\text { Transports multiple substances and creatinine from } \\
\text { blood to renal epithelia. }\end{array}$ & $\begin{array}{l}\text { [Creatinine is a biomarker for } \\
\text { IRI and kidney diseases] }\end{array}$ & & 0.5 & 0.6 & $\begin{array}{l}\text { Chu et al., 2016; Shen } \\
\text { et al., } 2017\end{array}$ \\
\hline CYB5B & $\begin{array}{l}\text { cytochrome B5 } \\
\text { type B }\end{array}$ & $\begin{array}{l}\text { Mitochondria: } \\
\text { Enzyme }\end{array}$ & $\begin{array}{l}\text { Membrane-bound hemoprotein in electron transport } \\
\text { chain }\end{array}$ & & & 0.5 & 0.6 & James et al., 2012 \\
\hline SLCO4C1 & $\begin{array}{l}\text { Organic anion } \\
\text { transporter } \mathrm{M} 1\end{array}$ & $\begin{array}{l}\text { PM: } \\
\text { Transporter }\end{array}$ & Transports uremic toxin from blood to renal epithelia. & $\begin{array}{l}\text { [Increase SLCO4C1 attenuates } \\
\text { CKD] }\end{array}$ & $\begin{array}{l}\text { Treatment of } \\
\text { hypertension, } \\
\text { inflammation }\end{array}$ & 0.5 & 0.5 & Suzuki et al., 2011 \\
\hline AQP7 & Aquaporin 7 & $\begin{array}{l}\text { PM: } \\
\text { Transporter }\end{array}$ & $\begin{array}{l}\text { Transports glycol. Activates insulin secretion and } \\
\text { regulates glucose and lipid metabolism. }\end{array}$ & $\begin{array}{l}\text { [High urine glycerol is observed } \\
\text { in acute renal failure] }\end{array}$ & & 0.5 & 0.5 & $\begin{array}{l}\text { Rodríguez et al., 2011; } \\
\text { Sohara et al., } 2006\end{array}$ \\
\hline SLC2A5 & $\begin{array}{l}\text { Glucose } \\
\text { transporter } 5\end{array}$ & $\begin{array}{l}\text { PM: } \\
\text { Transporter }\end{array}$ & $\begin{array}{l}\text { Fructose transporter. Expression is altered by diabetes } \\
\text { and inflammation }\end{array}$ & s. & 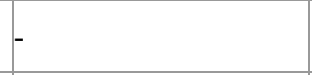 & 0.4 & 0.6 & $\begin{array}{l}\text { Douard and Ferraris, } \\
2008\end{array}$ \\
\hline CMKLR1 & $\begin{array}{l}\text { Chemerin } \\
\text { receptor }\end{array}$ & $\begin{array}{l}\text { PM: } \\
\text { GPCR }\end{array}$ & $\begin{array}{l}\text { A GPCR which modulates signals to reduce immune } \\
\text { response and enhance angiogenesis }\end{array}$ & $\begin{array}{l}\text { [Chimerin is induced in fibrosis } \\
\text { rat model] }\end{array}$ & $\begin{array}{l}\text { Treatment of } \\
\text { inflammation }\end{array}$ & 0.4 & 0.6 & Mocker et al., 2019 \\
\hline
\end{tabular}


1246 Table 2. Candidate transporters from mass spectrometry analysis of the BBMVs from IRI

1247 mouse kidneys. The list is arranged by the fold change.

\begin{tabular}{|c|c|c|c|c|c|c|c|c|}
\hline Transporters & Accession & $\begin{array}{c}\log _{2} \text { fold } \\
4 \mathrm{~h} \mathrm{IRI} / \\
\text { sham } \\
\end{array}$ & $\begin{array}{c}\text { p-value of } \\
\text { 4h IRI/ } \\
\text { sham }\end{array}$ & $\begin{array}{c}\log _{2} \text { fold } \\
\text { 8h IRI/ } \\
\text { sham } \\
\end{array}$ & $\begin{array}{c}\text { p-value of } \\
\text { 8h IRI/ } \\
\text { sham } \\
\end{array}$ & Peptides & $\begin{array}{l}\text { Score } \\
\text { Mascot }\end{array}$ & $\begin{array}{l}\text { Abundance } \\
\text { in sham }\end{array}$ \\
\hline \multicolumn{9}{|c|}{ Transport proteins found to be increased } \\
\hline Slc7a1/Cat1 & Q09143 & 0.8 & 0.12 & 1.3 & 0.01 & 1 & 131 & $2.6 \mathrm{E}+06$ \\
\hline Slc1a5/Asct2 & P51912 & 0.4 & 0.10 & 0.7 & 0.09 & 4 & 767 & $1.5 \mathrm{E}+07$ \\
\hline \multicolumn{9}{|c|}{ Transport proteins found to be decreased } \\
\hline Slc36a1/Pat1 & Q8K4D3 & -1.2 & 0.08 & -1.0 & 0.12 & 3 & 103 & $5.4 \mathrm{E}+06$ \\
\hline Slc2a5/Glut5 & Q9WV38 & -1.2 & 0.01 & -0.8 & 0.04 & 2 & 1,140 & $6.5 \mathrm{E}+07$ \\
\hline Slco4c1/Oatp-m1 & Q8BGD4 & -1.1 & 0.00 & -0.9 & 0.00 & 9 & 4,011 & $1.5 \mathrm{E}+08$ \\
\hline Slc22a13/Oat10 & Q6A4L0 & -1.1 & 0.03 & -0.8 & 0.03 & 15 & 5,948 & $5.6 \mathrm{E}+08$ \\
\hline Slc22a7/Oat2 & Q91WU2 & -0.9 & 0.00 & -0.6 & 0.02 & 13 & 6,100 & $4.3 \mathrm{E}+08$ \\
\hline Slc6a18/B ${ }^{0}$ at3 & O88576 & -0.8 & 0.17 & -0.6 & 0.25 & 11 & 4,310 & $2.1 \mathrm{E}+08$ \\
\hline Slc5a8/Smct1 & Q8BYF6 & -0.8 & 0.05 & -0.7 & 0.02 & 25 & 26,044 & $2.9 \mathrm{E}+09$ \\
\hline Slc15a2/Pept2 & Q9ES07 & -0.7 & 0.01 & -1.1 & 0.05 & 9 & 2,379 & $4.6 \mathrm{E}+07$ \\
\hline Slc5a12/Smet2 & Q49B93 & -0.6 & 0.01 & -0.9 & 0.01 & 12 & 4,725 & $1.6 \mathrm{E}+08$ \\
\hline $\begin{array}{l}\text { TMEM27/ } \\
\text { Collectrin }^{\text {b }}\end{array}$ & Q9ESG4 & -0.4 & 0.01 & -0.1 & 0.17 & 9 & 23,686 & $3.3 \mathrm{E}+09$ \\
\hline
\end{tabular}




\section{Supplement Figures}

Figure supplement 1: Wiriyasermkul, et al.

A

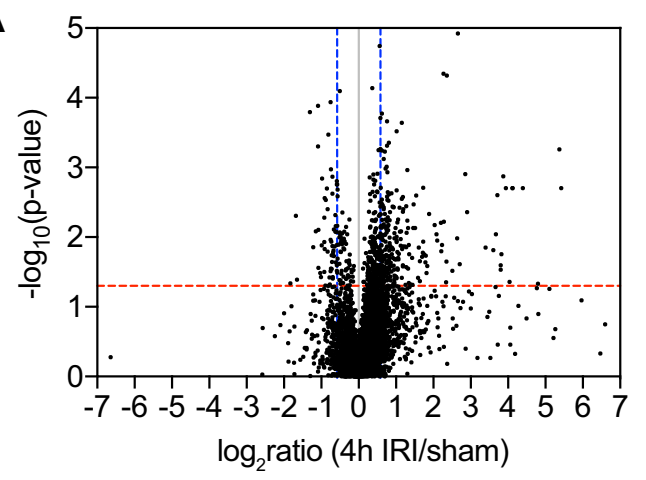

B

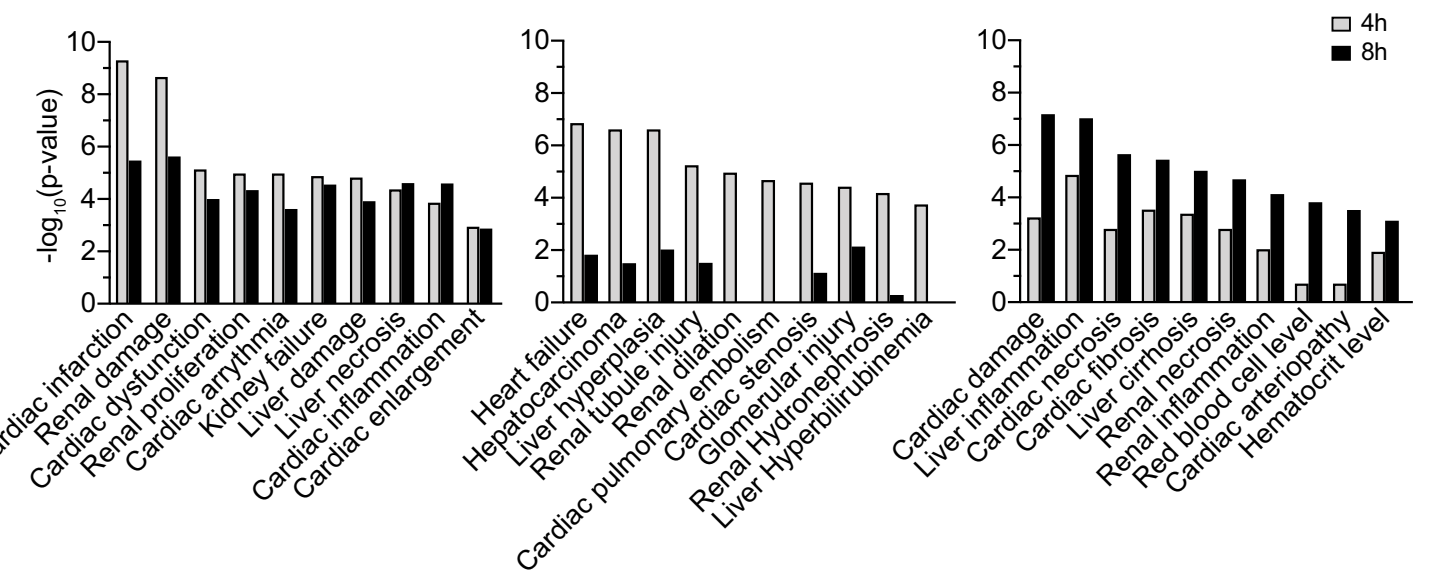

C

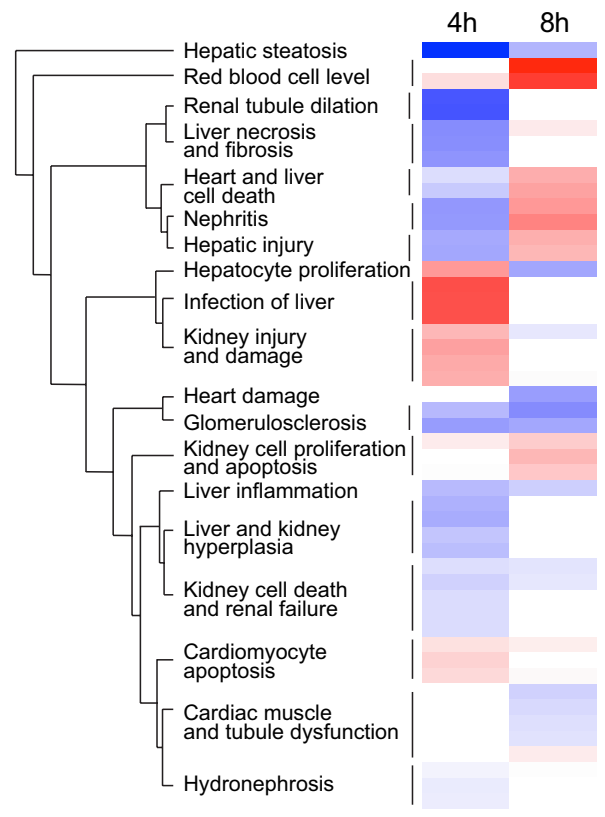

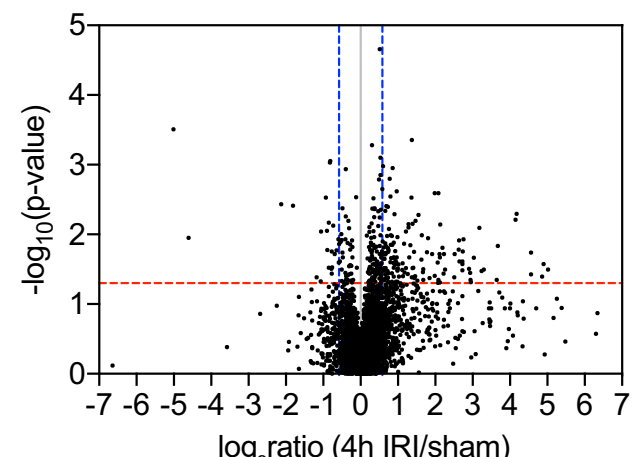

$\log _{2}$ ratio (4h IRI/sham)

$4 \mathrm{~h}$

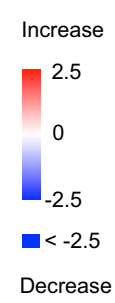

Decrease 
1251 A) Volcano plots of proteome identified from renal BBMVs of the IRI model. The $\log _{2}$ fold of

$12524 \mathrm{~h} \mathrm{IRI/sham} \mathrm{(left)} \mathrm{or} 8 \mathrm{~h} \mathrm{IRI/sham} \mathrm{(right)} \mathrm{were} \mathrm{plotted} \mathrm{against}-\log _{10}$ of p-value. Blue lines

1253 indicate protein fold change of $1.5\left(\log _{2}\right.$ fold change $\left.=0.58\right)$ and red line indicates p-value of

$12540.05\left(-\log _{10} p\right.$-value $\left.=1.3\right)$. One protein which is out of range is omitted for resolution purpose.

1255 B) Top-10 organ pathologies that are presented in both $4 \mathrm{~h}$ and $8 \mathrm{~h}$ IRI (left), dominant in $4 \mathrm{~h}$ IRI

1256 (middle), and dominant in 8h IRI (right). C) Hierarchical heatmap of organ pathologies

1257 corresponding to B). Colors indicate predicted pathologies (z-score). 
bioRxiv preprint doi: https://doi. org/10.1101/2020.08 10.244822; this version posted August 10, 2020. The copyright holder for this preprint (which was not certified by peer review) is the author/funder, who has granted bioRxiv a license to display the preprint in perpetuity. It is made available under aCC-BY 4.0 International license.

Wiriyasermkul, et al.

Figure supplement 2: Wiriyasermkul, et al.

A

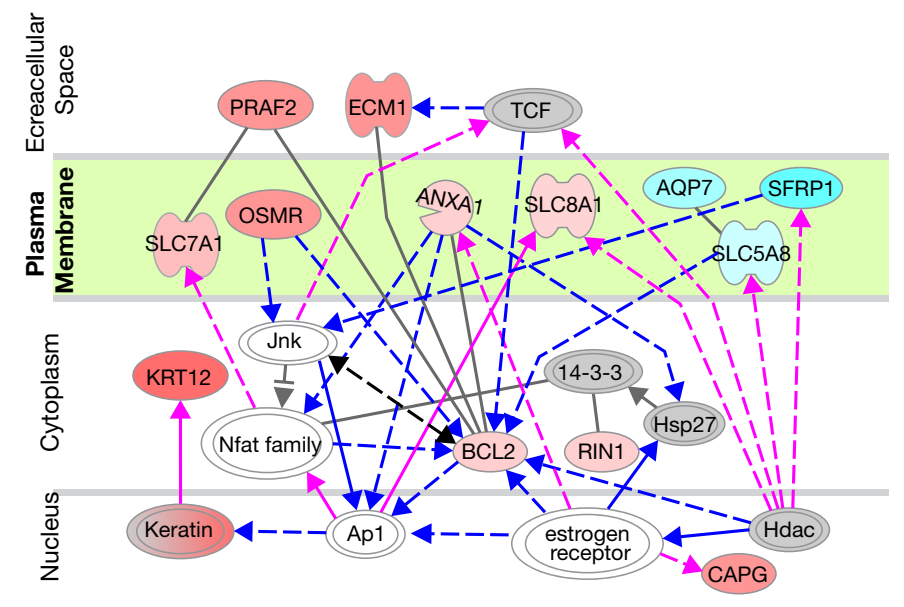

B
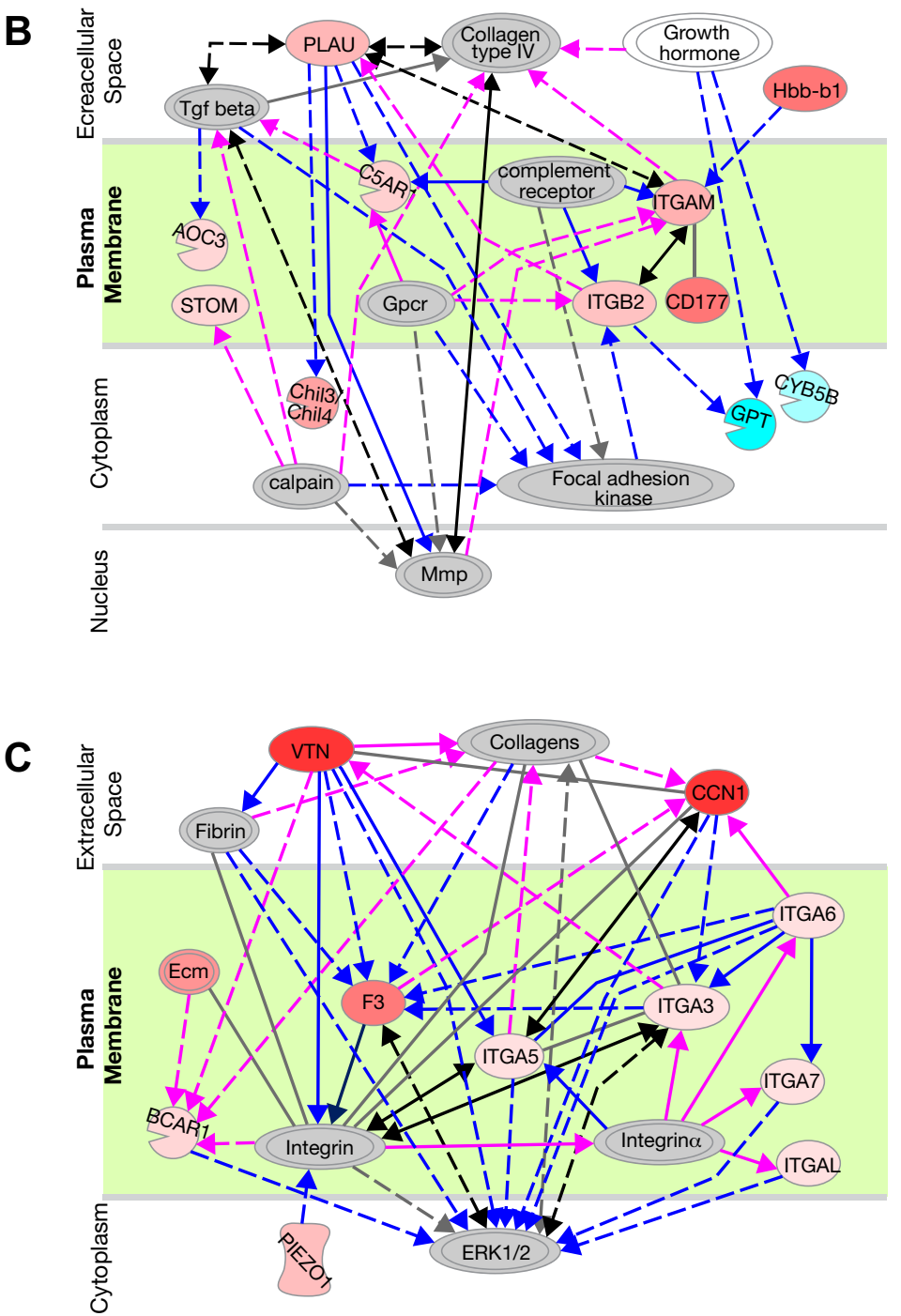

1258 Figure supplement 2: Predicted pathways in response to 8h IRI 
1259 Identified proteins from renal BBMVs, which are significantly altered more or less than 1.5-

1260 fold change (p-value $<0.05)$ in $8 \mathrm{~h}$ IRI, were curated into networks by IPA and literature. A -

$1261 \mathrm{C}$ networks indicate the proteins which are highly altered at $8 \mathrm{~h}$ compared to $4 \mathrm{~h}$ IRI. Protein

1262 expressions that are upregulated and downregulated are shown in red and cyan, respectively,

1263 with intensity shading corresponding to the degree of fold change. Proteins are shaped by

1264 categories and double cycles indicate protein complexes. Solid and dash lines represent direct

1265 and indirect interactions, respectively. Lines are colored for contrast observation in which blue

1266 and magenta lines imply activation to regulators and targeting proteins, respectively. A)

1267 Network involved in connective tissue development and function via ANXA1 and BCL2

1268 regulators. B) Network involved in cell-cell interaction and system development. C) Network

1269 involved in cell morphology, cell-cell interaction, and movement via Integrin signaling. 
Wiriyasermkul, et al.

\section{Figure supplement 3: Wiriyasermkul, et al.}

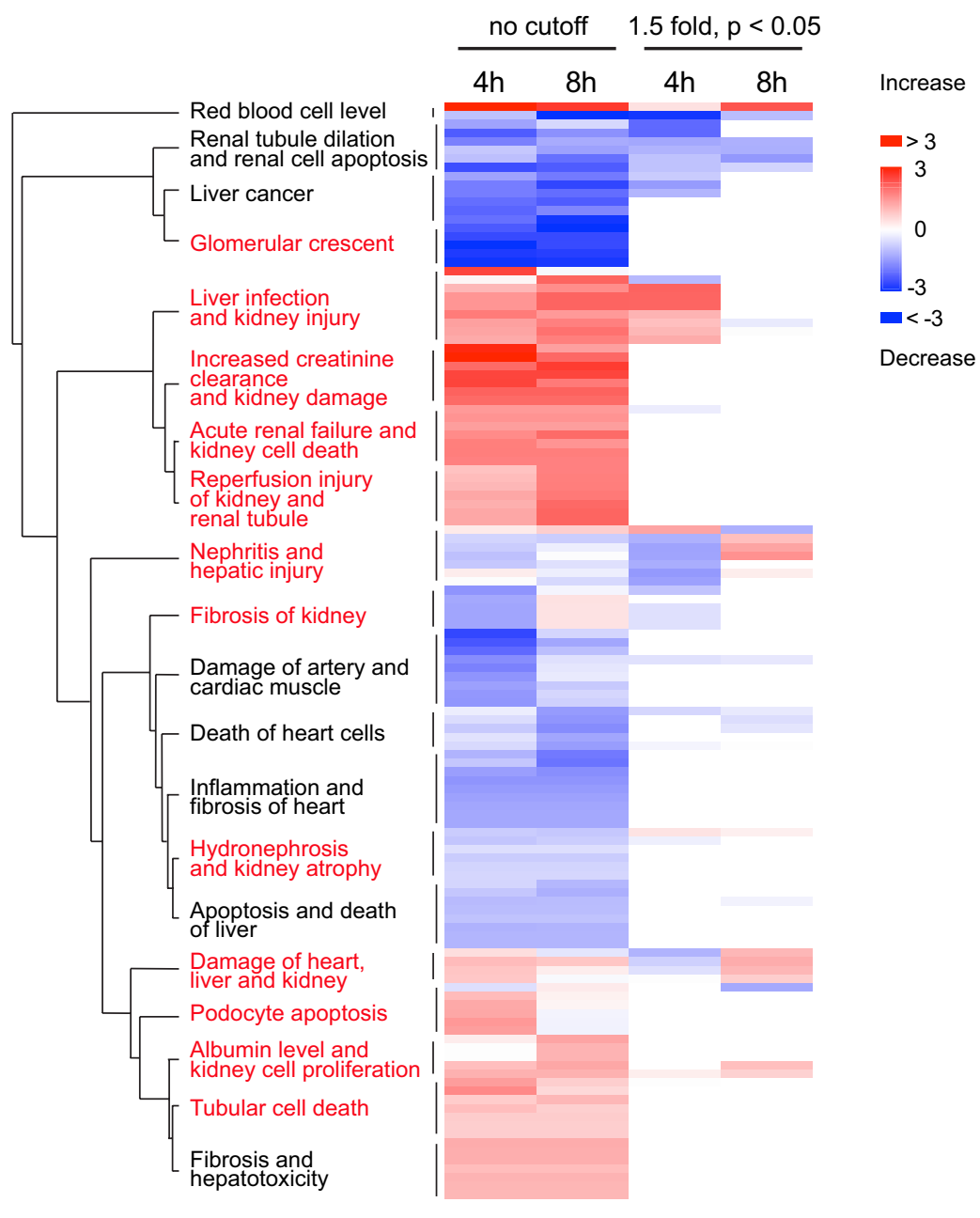

1270 Figure supplement 3: Hierarchical heatmap of abnormalities from all identified proteins.

1271 Heatmap of all proteome with no cut-off value compared to data from the cut-off values of 1.5-

1272 fold change and $0.05 \mathrm{p}$-value $(1.5$ fold, $\mathrm{p}<0.05)$. The abnormalities highlighted in red are those

1273 involved with kidney. Colors indicate predicted pathologies (z-score). 
Wiriyasermkul, et al.

\section{Figure supplement 4: Wiriyasermkul, et al.}

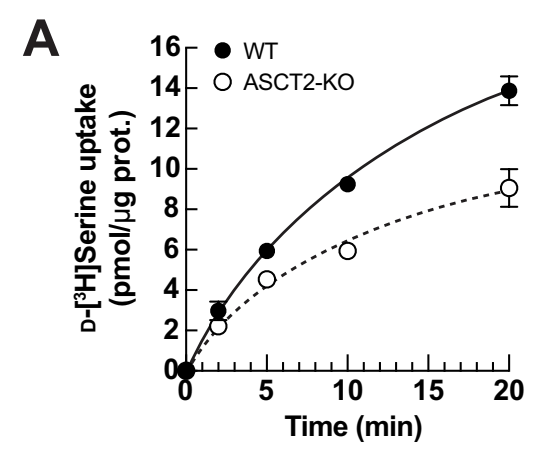

B

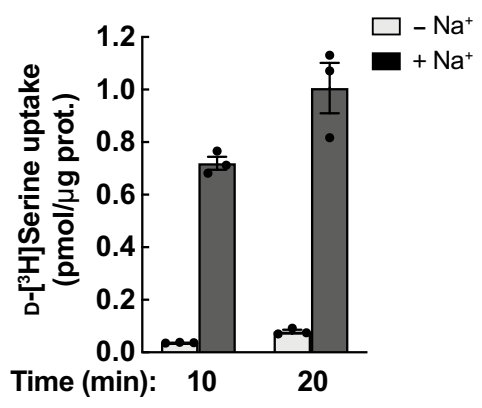

C

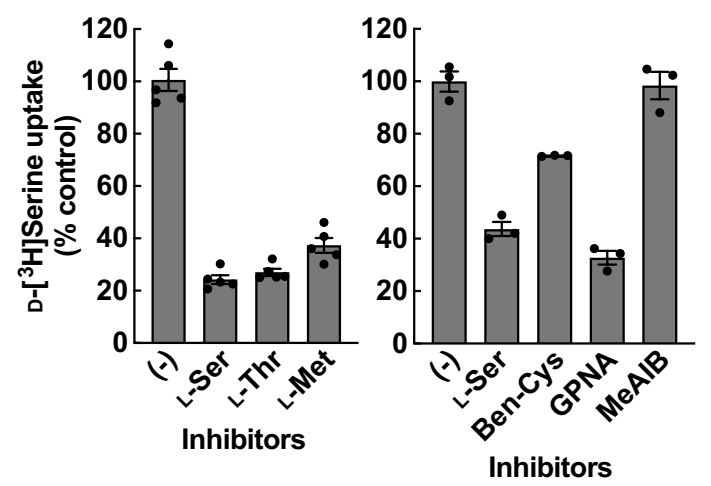

D

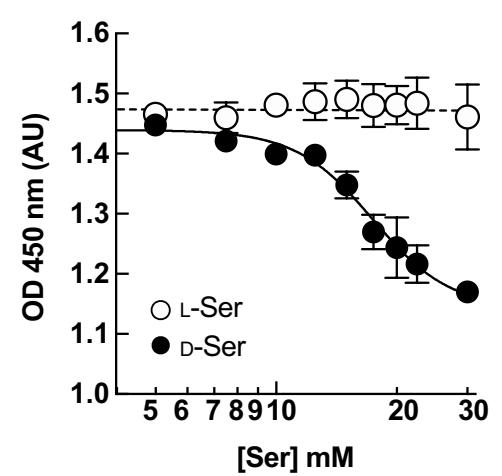

1274 Figure supplement 4: Characterization of ASCT2 as a D-serine transporter in HEK293

1275 cells

1276 A) Time course of $100 \mu \mathrm{M}$ D- $\left[{ }^{3} \mathrm{H}\right]$ serine transport $(10 \mathrm{Ci} / \mathrm{mol})$ was measured in wild-type (WT) 1277 and ASCT2-knockout (ASCT2-KO) HAP1 cells. D- $\left[{ }^{3} \mathrm{H}\right]$ Serine transport in the cells was 1278 measured in PBS $\mathrm{pH}$ 7.4. $\mathrm{n}=3$. B) Transport of $10 \mu \mathrm{M} \mathrm{D}-\left[{ }^{3} \mathrm{H}\right]$ serine was measured for 10 or 127920 min in HEK293 cells in the presence or absence of $\mathrm{Na}^{+} . \mathrm{n}=3$. C) Inhibition of $\mathrm{D}-\left[{ }^{3} \mathrm{H}\right]$ serine 
1280 transport by several compounds. The uptake was measured for $10 \mathrm{~min}$ in PBS buffer. Left: 5

$1281 \mu \mathrm{M}$ D- $\left[{ }^{3} \mathrm{H}\right]$ serine uptake was measured in the presence or absence of $2 \mathrm{mM}$ L-amino acids. $\mathrm{n}=$

1282 4. Right: $2 \mu \mathrm{M} \mathrm{D}-\left[{ }^{3} \mathrm{H}\right]$ serine uptake was measured in the presence or absence of $1 \mathrm{mM}$

1283 inhibitors; Ben-Cys: $S$-benzyl-L-cysteine, a non-specific inhibitor of ASCT2; GPNA: L- $\gamma$ -

1284 glutamyl-p-nitroanilide, an inhibitor of ASCT2, SNATs and LATs; MeAIB: 2-

1285 (methylamino)isobutyric acid, a system A inhibitor. $\mathrm{n}=3$. D) Cell-growth measurement (XTT

1286 assay) of HEK293 cells treated with either L-serine (opened circles) or D-serine (closed circles)

1287 at different concentrations for two days. In contrast to L-serine which did not alter cell viability,

1288 D-serine reduced cell growth in a concentration-dependent manner. D-Serine inhibition curve

1289 was fitted to non-linear regression of $\log _{10}$ [D-Ser] v.s. cell growth, resulting in $\mathrm{IC}_{50}$ of $17.4 \mathrm{mM}$ and minimum growth at OD $450 \mathrm{~nm}$ of $1.15 \mathrm{AU} . \mathrm{n}=3-5$. 
Figure supplement 5: Wiriyasermkul, et al.
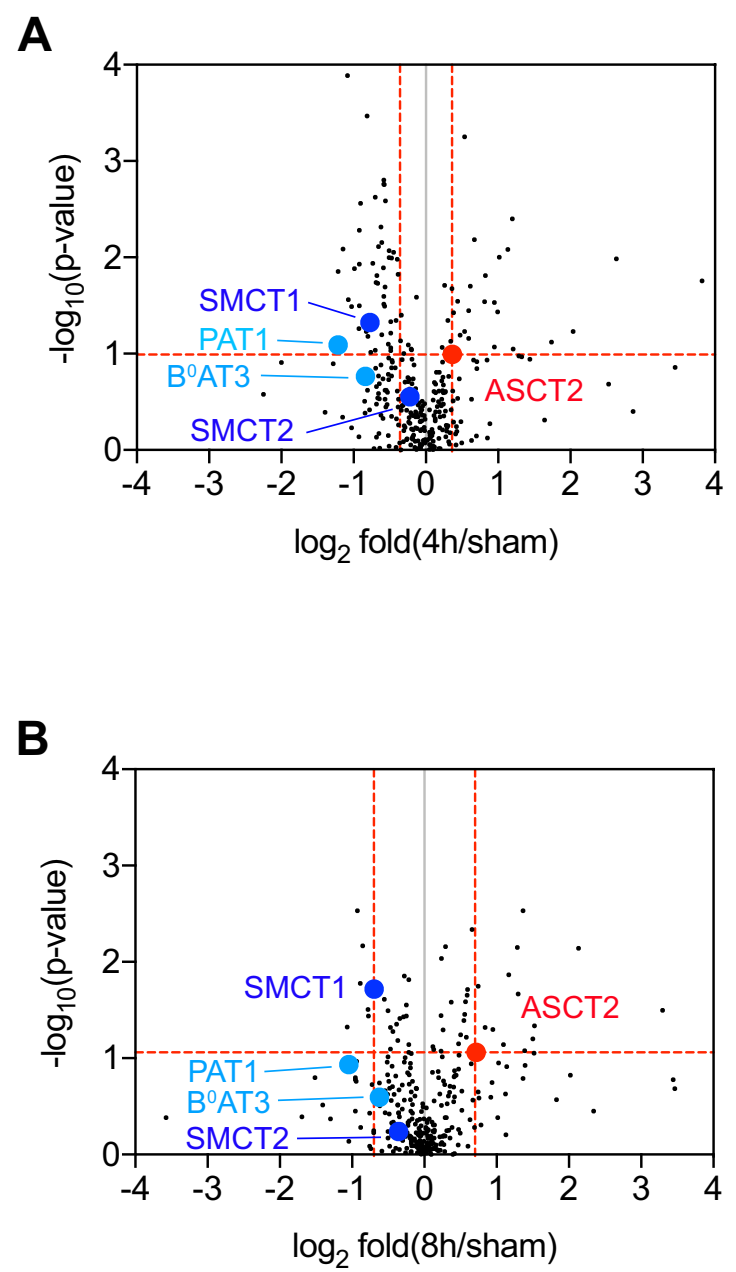

1291 Figure supplement 5: SMCTs, PAT1, and $\mathbf{B}^{\mathbf{0}} \mathrm{AT3}$ in the volcano plots of membrane 1292 transport proteins

1293 Volcano plot of 319 membrane transport proteins is identical to the plot presented in Figure

1294 4A. Position of SMCT1, SMCT2, PAT1, and B ${ }^{0}$ AT3 are indicated. 
Wiriyasermkul, et al.

Figure supplement 6: Wiriyasermkul, et al.

A

Clone: Mock SMCT1 SMCT2

ASCT2-siRnA: $\overline{-}+\overline{-+} \overline{-+}$

anti-ASCT2

B

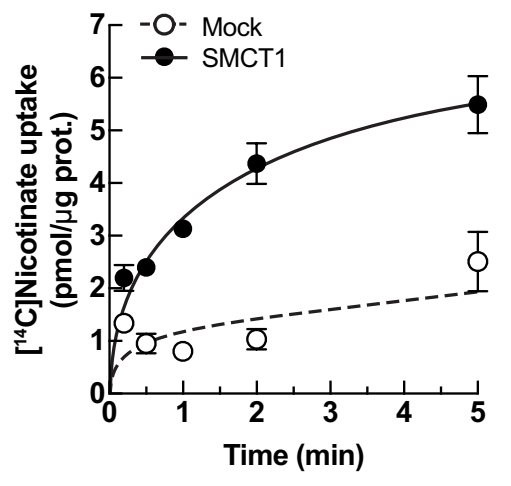

D

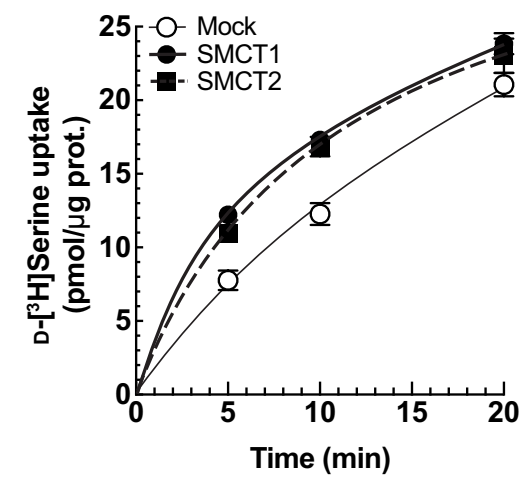

E

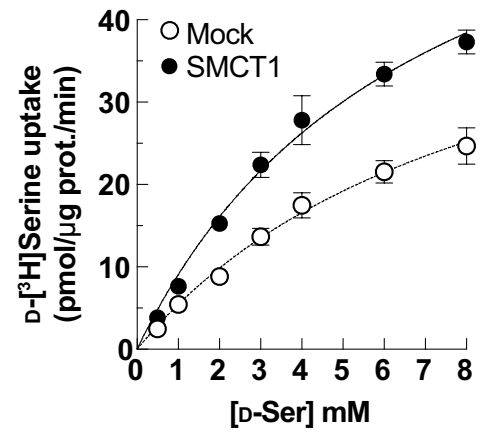

C

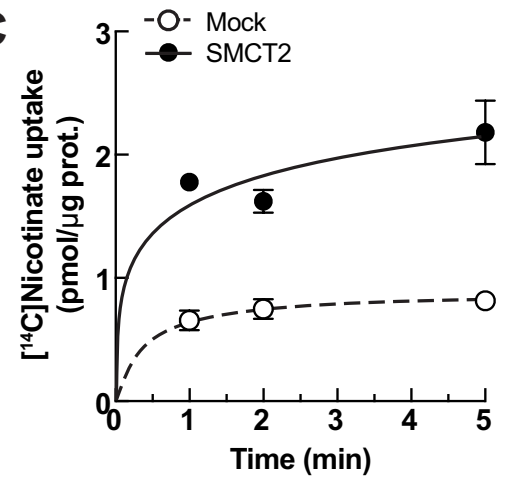


Wiriyasermkul, et al.

\section{SMCT2 stable cell lines}

1298 A) Western blot of membrane fractions from FlpInTR-Mock, -SMCT1, and -SMCT2 cells with 1299 ASCT2-siRNA transfection. Flp-In T-REx 293 stably expressing SMCT1 (SMCT1) and 1300 SMCT2 (SMCT2), as well as Mock, were transfected with ASCT2-siRNA for two days. 1301 Membrane proteins were extracted from crude membrane fractions and subjected to Western 1302 blot analysis. ASCT2 knockdown efficiency was evaluated by anti-hASCT2 antibody. 1303 Expression of SMCT1 and SMCT2 were verified by anti-FLAG antibody. B - C) Evaluation 1304 of SMCT1 and SMCT2 function by transport assay. Time course of $50 \mu \mathrm{M}\left[{ }^{14} \mathrm{C}\right]$ nicotinate uptake was measured for $0.5-5$ min in FlpInTR-SMCT1 (B) and FlpInTR-SMCT2 (C) cells,

1306 compared to mock cells (Mock). $\mathrm{n}=3$. D) Time course of $100 \mu \mathrm{M} \mathrm{D}-\left[{ }^{3} \mathrm{H}\right]$ serine uptake in 1307 FlpInTR-SMCT1 (SMCT1), FlpInTR-SMCT2 (SMCT2), and Mock cells. The experiment was 1308 carried out in a similar way to experiment in Figure 6A except that the cells were not subjected 1309 to ASCT2 knockdown. $\mathrm{n}=4$. E) Raw data of Figure $6 \mathrm{C}$ before subtraction with the uptake data 1310 in Mock cells. D- $\left[{ }^{3} \mathrm{H}\right]$ serine uptake in FlpIn293TR-SMCT1 compared to FlpIn293TR-Mock 1311 cells. The uptake values were fitted to Michaelis-Menten plot. $\mathrm{n}=3-4$. 
Wiriyasermkul, et al.

\section{Figure supplement 7: Wiriyasermkul, et al.}

A

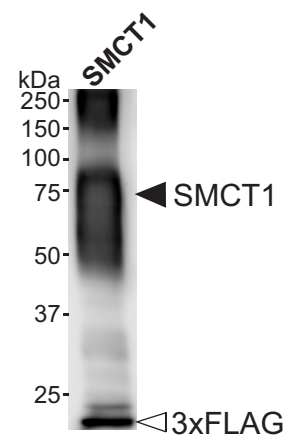

B

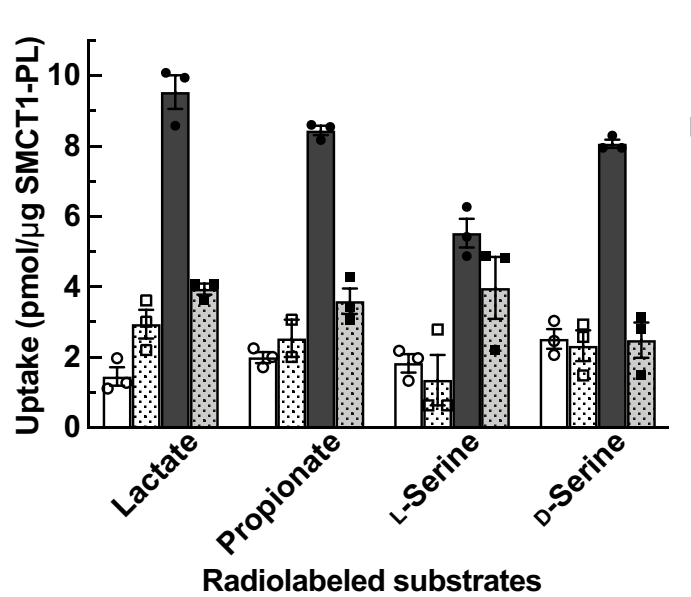

$\square \mathrm{K}^{+}$

$\because \mathrm{K}^{+}+$lbuprofen

$\square \mathrm{Na}^{+}$

$\mathrm{Na}^{+}+$Ibuprofen

C

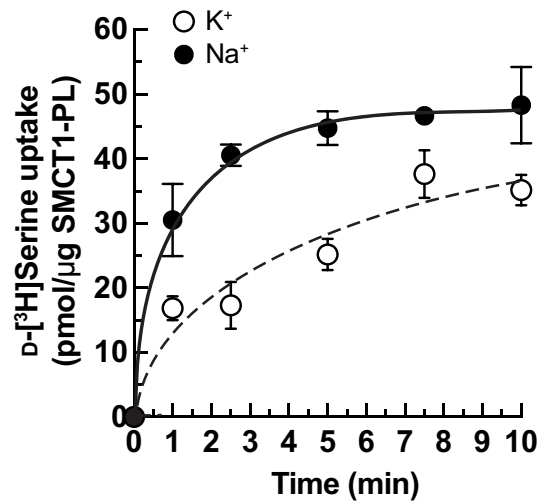

1312 Figure supplement 7: Purification of SMCT1 and functional characterization

1313 A) Western blot of purified SMCT1 from pCMV14-SMCT1-transfected Expi293F cells. The

1314 protein was detected by anti-FLAG antibody. The closed arrowhead indicates purified SMCT1,

1315 whereas the opened arrowhead is 3xFLAG peptides for the elution of the purified SMCT1. The

1316 bands above $250 \mathrm{kDa}$ probably include SMCT1, which is aggregated at the top of SDS- 
1317 polyacrylamide gel. B) Raw data of the ibuprofen effect presented in Figure 7B before

1318 subtraction with the uptake in $\mathrm{K}^{+}$-buffer. Uptake of $\left[{ }^{3} \mathrm{H}\right]$ lactate, $\left[{ }^{3} \mathrm{H}\right]$ propionate, $\mathrm{L}-\left[{ }^{3} \mathrm{H}\right]$ serine,

1319 and $\mathrm{D}-\left[{ }^{3} \mathrm{H}\right]$ serine (all $50 \mu \mathrm{M}$ ) in SMCT1 proteoliposomes (SMCT1-PL). The uptake was

1320 measured in the $\mathrm{Na}^{+}$buffer $\left(\mathrm{Na}^{+}\right)$or $\mathrm{Na}^{+}$-free buffer $\left(\mathrm{K}^{+}\right)$in the presence or absence of $1 \mathrm{mM}$

1321 ibuprofen. $n=3$. C) Raw data of $\mathrm{D}-\left[{ }^{3} \mathrm{H}\right]$ serine transport in SMCT1-PL presented in Figure 7C

1322 prior to subtraction with the uptake in $\mathrm{K}^{+}$-buffer. Time course of $\mathrm{D}-\left[{ }^{3} \mathrm{H}\right]$ serine $(200 \mu \mathrm{M})$

1323 transport was measured in the SMCT1 proteoliposomes in $\mathrm{Na}^{+}$-buffer $\left(\mathrm{Na}^{+}\right)$or $\mathrm{Na}^{+}$-free buffer

$1324\left(\mathrm{~K}^{+}\right)$. 


\section{Figure supplement 8: Wiriyasermkul, et al.}
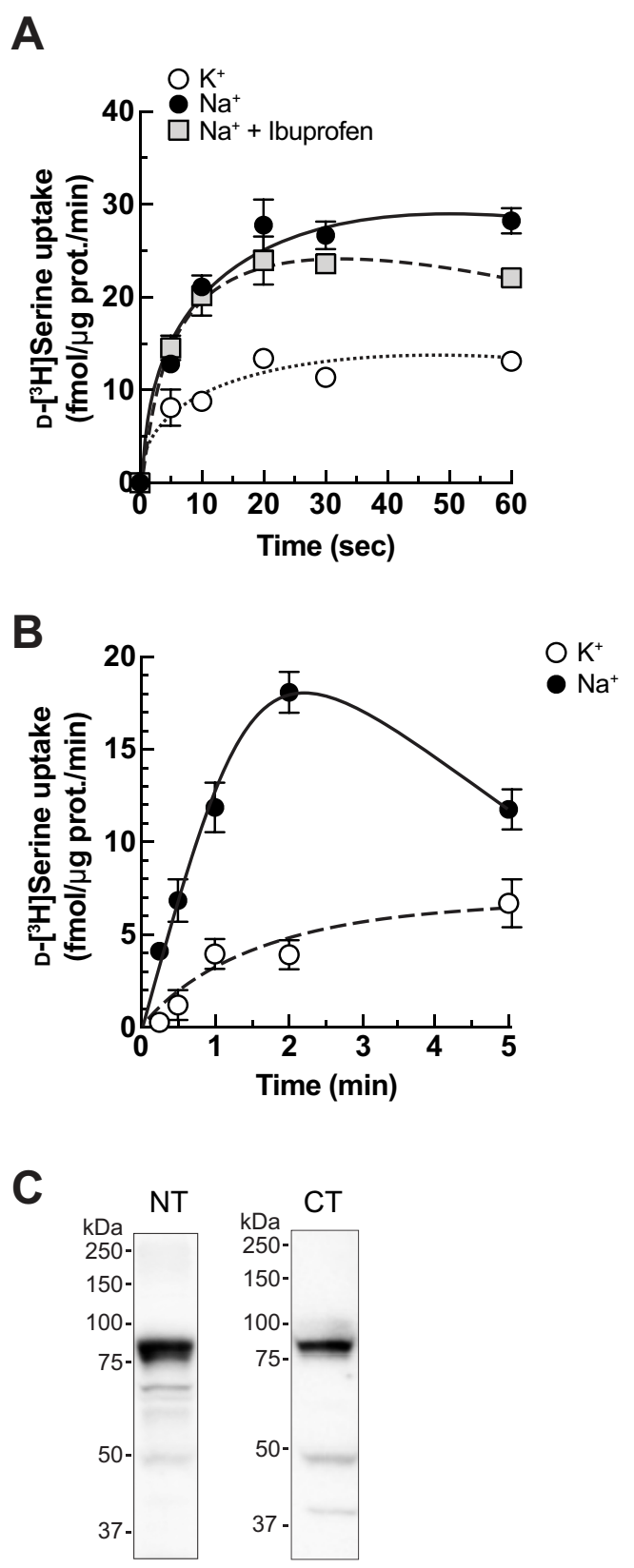

1325 Figure supplement 8: D-Serine transport and expression of Asct2 in mouse BBMVs

1326 A) Raw data of Figure 8A: D- $\left[{ }^{3} \mathrm{H}\right]$ Serine transport in BBMVs preloaded with $4 \mathrm{mM}$ L-

1327 glutamine. Time course of $10 \mu \mathrm{M}$ D- $\left[{ }^{3} \mathrm{H}\right]$ serine transport in L-glutamine-preloaded BBMVs in

$1328 \mathrm{Na}^{+}$-buffer $\left(\mathrm{Na}^{+}\right)$or $\mathrm{Na}^{+}$-free $\left(\mathrm{K}^{+}\right)$buffer in the presence or absence of $1 \mathrm{mM}$ ibuprofen. $\mathrm{n}=3$ 

made available under aCC-BY 4.0 International license.

Wiriyasermkul, et al.

1330 time points. The transport was measured in $\mathrm{Na}^{+}$-buffer (filled circles) or $\mathrm{Na}^{+}$-free buffer

1331 (opened circles). $\mathrm{n}=4$. C) Western blot of Asct2 in mouse kidney BBMVs using anti1332 mAsct2(NT) (left) or anti-mAsct2(CT) (right) antibodies. 
1333 Table supplement 1. List of proteins identified from proteome analysis of BBMVs from

1334 IRI mouse kidneys.

1335 Table supplement 1 is provided as an excel sheet which is submitted separately as a

1336 supporting file.

1337

1338

1339

1340

1341 Table supplement 2. Plasma membrane amino acid transporters identified from mass

1342 spectrometry of HEK293 membrane fraction

\begin{tabular}{llcccc}
\hline Transporter & Accession & Peptides & PSMs & $\begin{array}{c}\text { Score } \\
\text { Mascot }\end{array}$ & Abundance \\
\hline SLC1A3/EAAT1 & P43003 & 1 & 4 & 167 & $1.20 \mathrm{E}+07$ \\
SLC1A5/ASCT2 & Q15758 & 5 & 15 & 221 & $1.68 \mathrm{E}+08$ \\
SLC3A2/4F2hc & J3KPF3 & 15 & 46 & 815 & $3.62 \mathrm{E}+08$ \\
SLC6A15/B ${ }^{0}$ AT2 & Q9H2J7 & 2 & 2 & 46 & $1.28 \mathrm{E}+07$ \\
SLC7A1/CAT1 & B2R728 & 2 & 7 & 83 & $4.94 \mathrm{E}+07$ \\
SLC7A6/y ${ }^{+}$LAT2 & Q92536 & 1 & 1 & 31 & $7.15 \mathrm{E}+06$ \\
SLC38A2/SNAT2 & A8K6H9 & 1 & 2 & 88 & $2.82 \mathrm{E}+07$ \\
SLC38A9/SNAT9 & Q8NBW4 & 1 & 1 & 0 & $1.33 \mathrm{E}+07$ \\
\hline
\end{tabular}

1343 
A
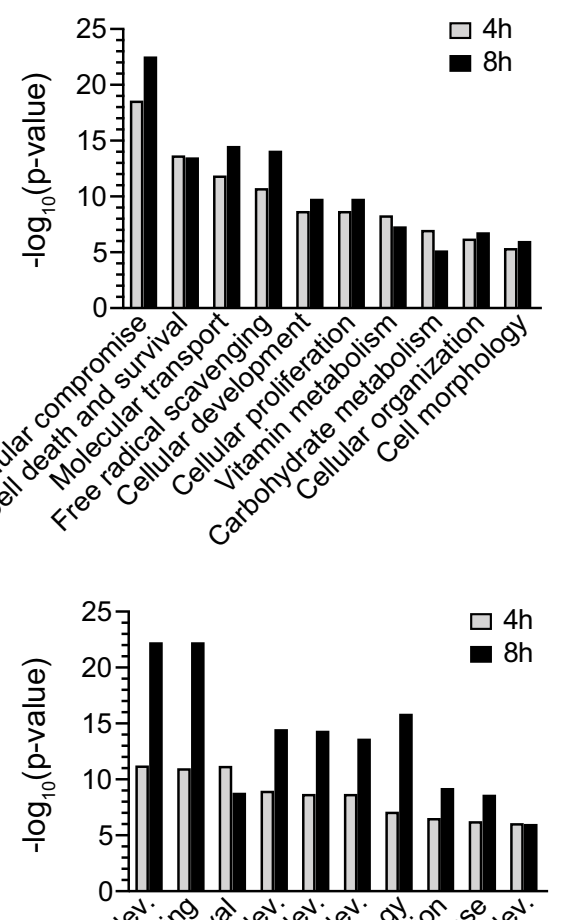

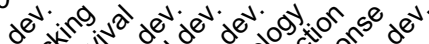

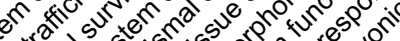

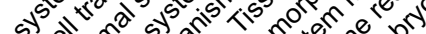

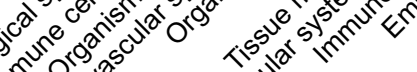

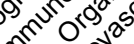
$\mathrm{c}^{\mathrm{x}^{\circ 0^{\circ}}}$

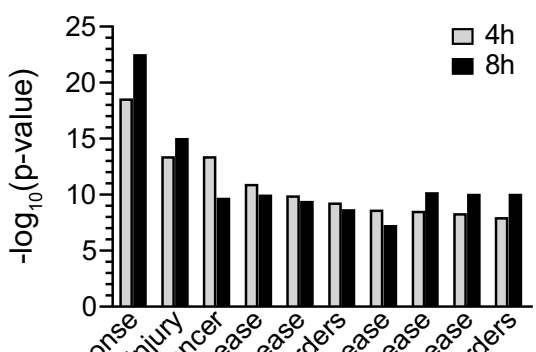

$4 \mathrm{~h}$

h

D
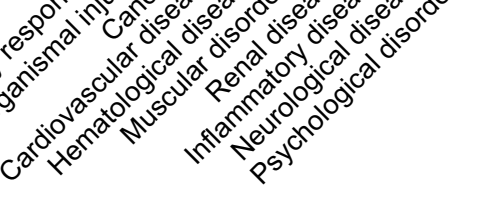

\section{E}

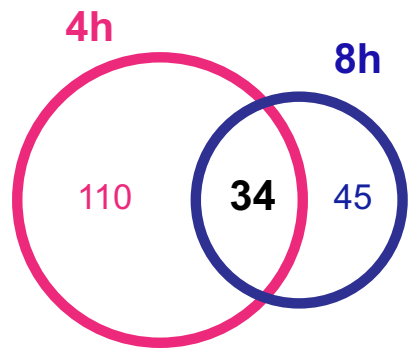

C

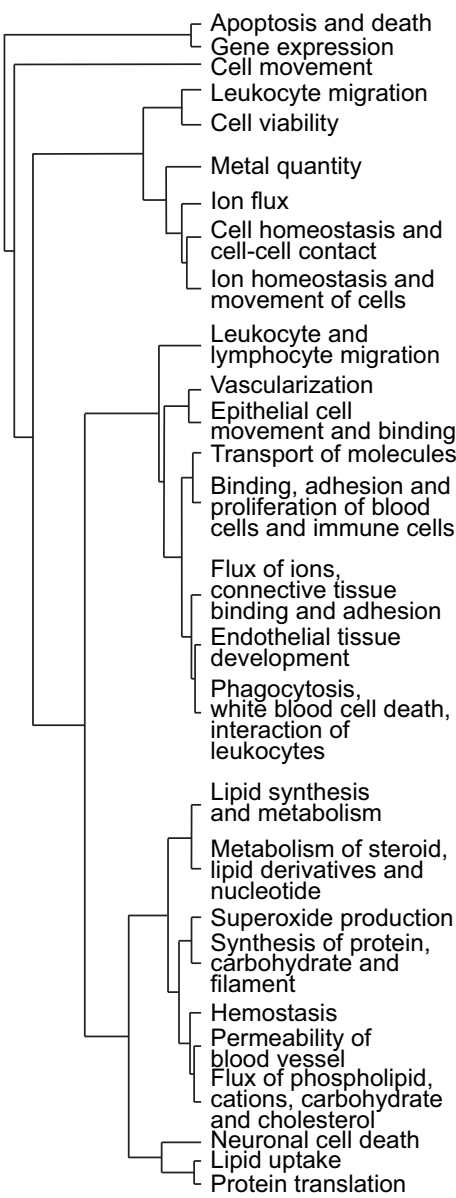

$>4$

4

2

$-2$

$-4$

Decrease
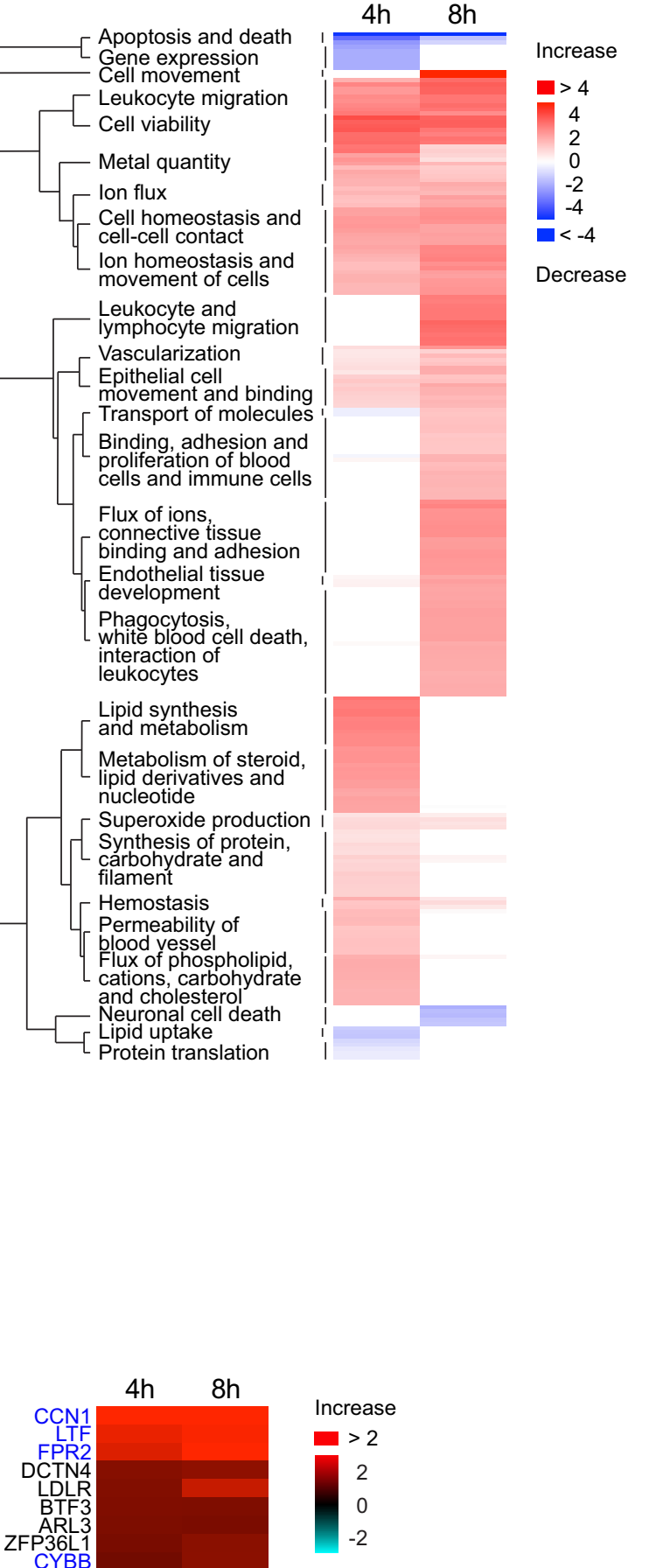

Decrease 


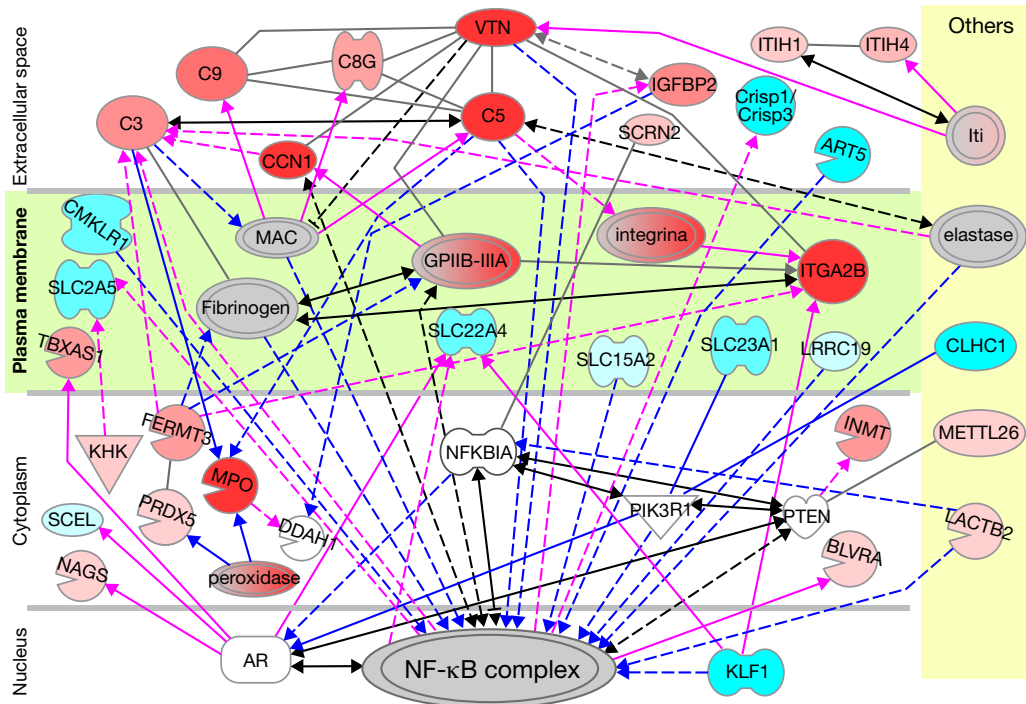

B Network of the rapid responses via MYC and PI3K complex

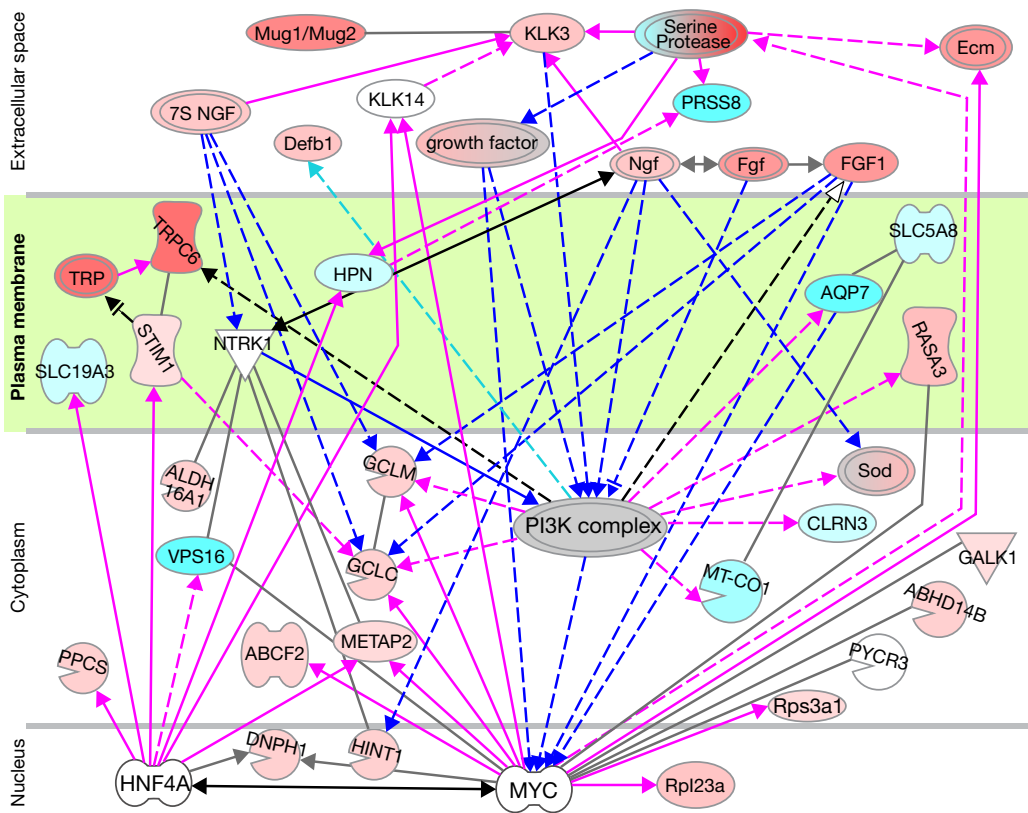

\section{Network of the prolonged responses via HDL and Akt}

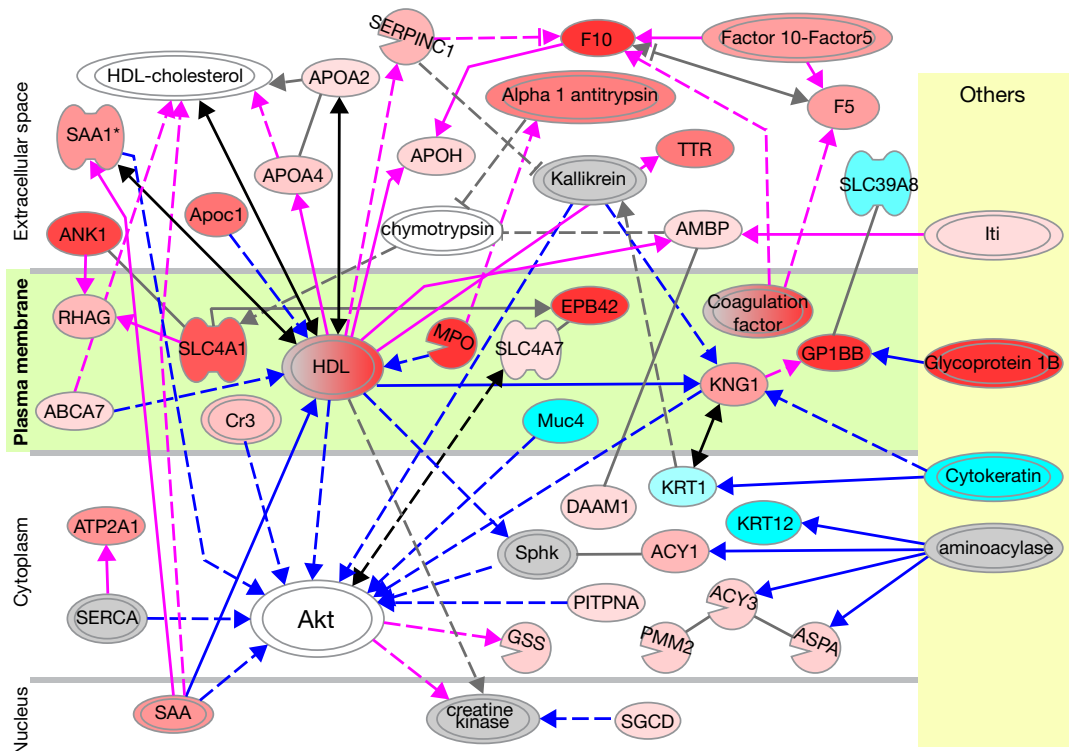


A
Ino
Inc
B
Inorganic cations Inorganic anions

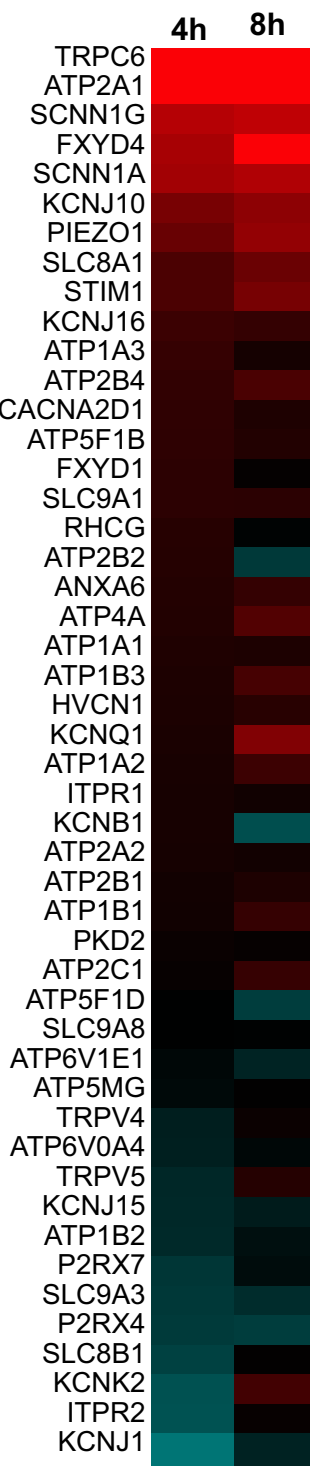

SLC39A7

SLC30A7

ATP6V1G1

ATP6V1A

ATP6V0A2

SLC11A2

ATP6V0D1

ATP6AP1

SLC13A1 ABCB7

SLC30A5

VDAC3

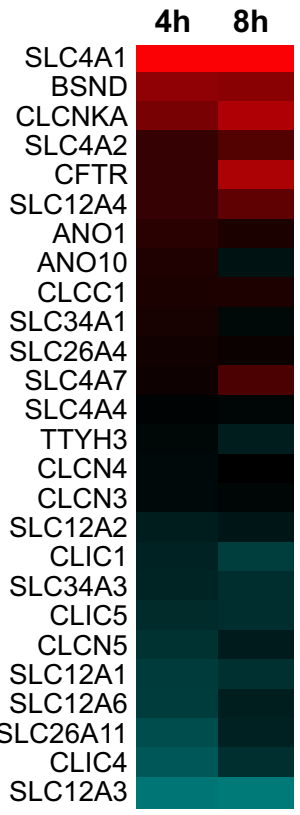

Metals

\begin{tabular}{|r|r|r|} 
& $\mathbf{4 h} \quad \mathbf{8 h}$ & SLC44A1 \\
SLC30A1 & & SLC44A2 \\
SLC39A6 & & SLC22A2 \\
VDAC2 & & SLC44A4 \\
\hline SLC39A10 & & SLC47A1 \\
VDAC1 & & SLC22A5 \\
ATP7A & & SLC22A4 \\
\hline
\end{tabular}

SLC31A1

SLC39A8
Carboxylates

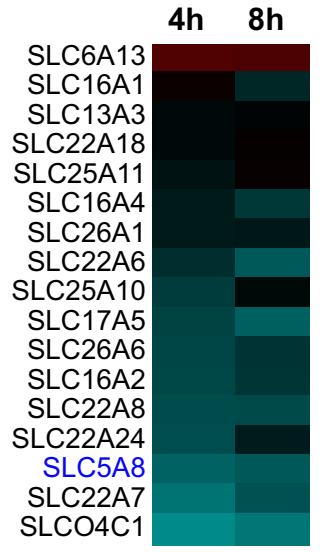

Amines

$4 h \quad 8 h$

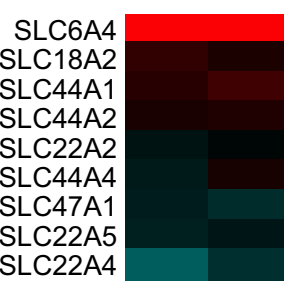

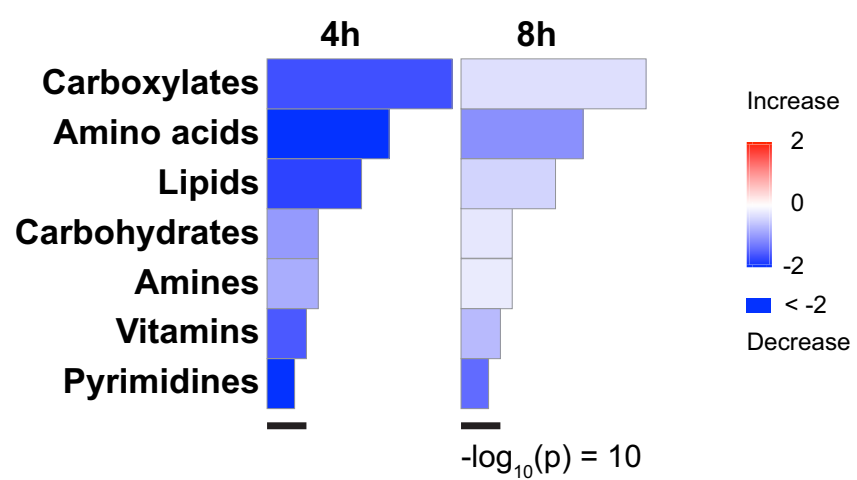

Amino acids

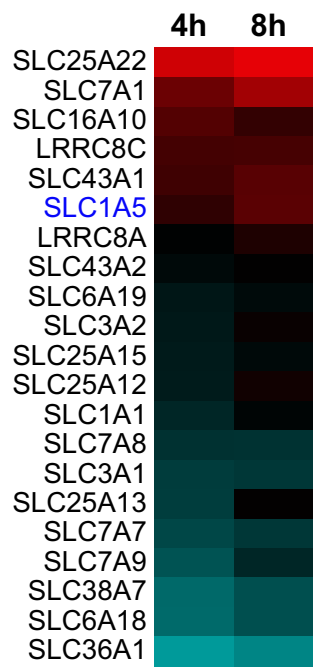

Carbohydrates

4h $8 \mathrm{~h}$

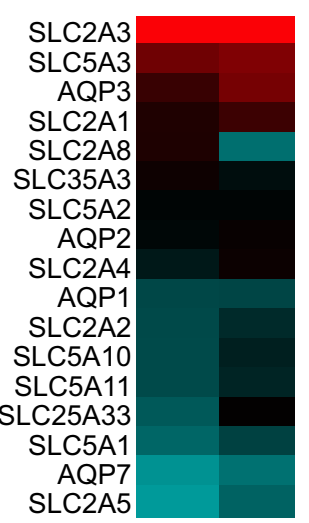

Lipids

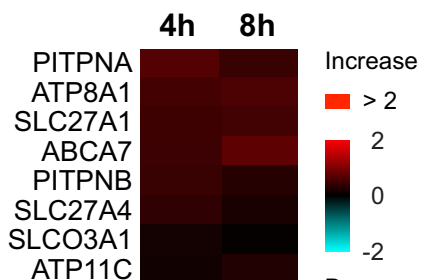

Decrease

SLC27A2

ABCD3

ABCA5

ANO6

SLCO2A1

ABCB1

$\mathrm{ABCC} 2$

ABCC6

ABCC 10

ATP11A

ABCD1

SLC10A2

ncrease

$-2$

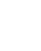




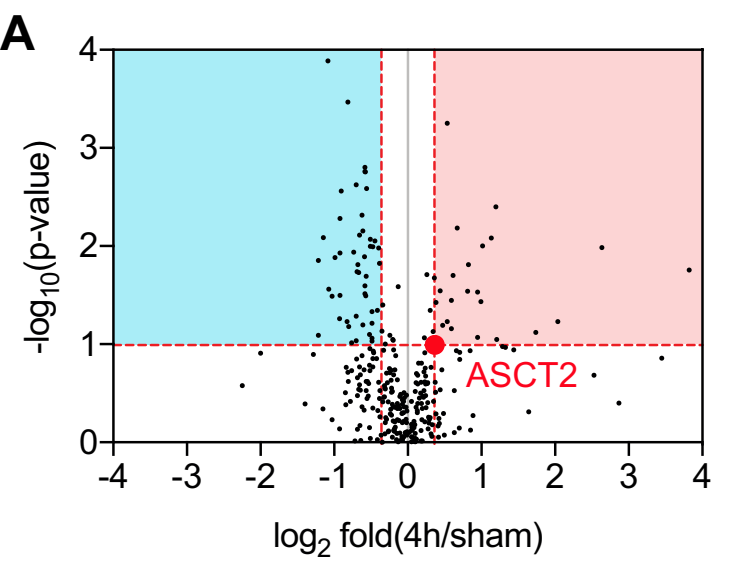

B

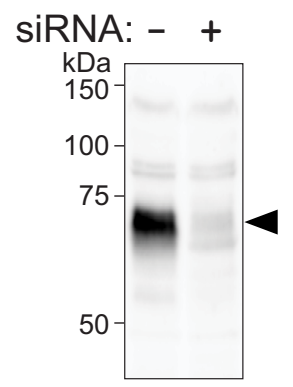

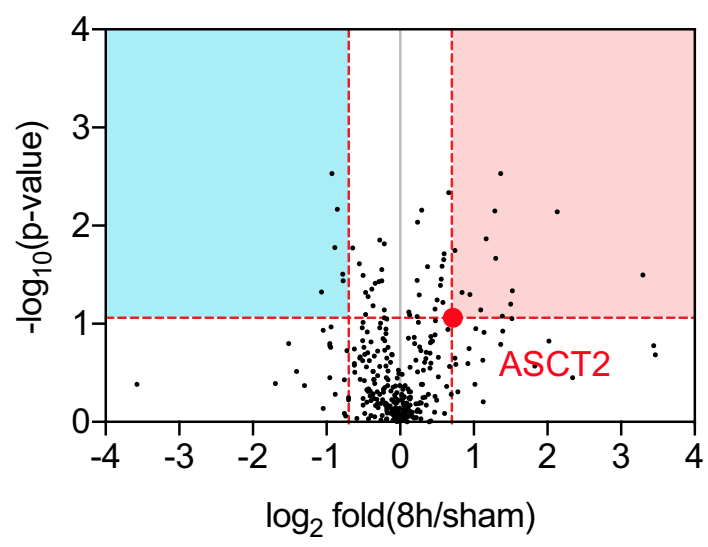

D

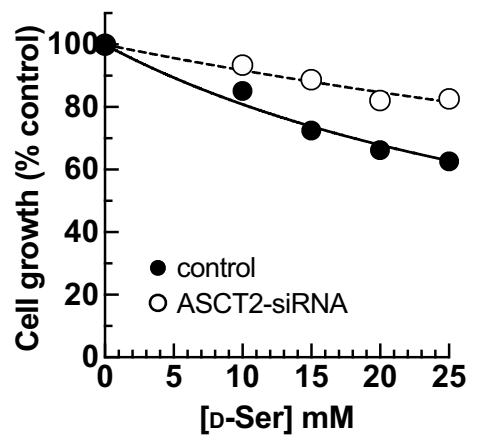


A

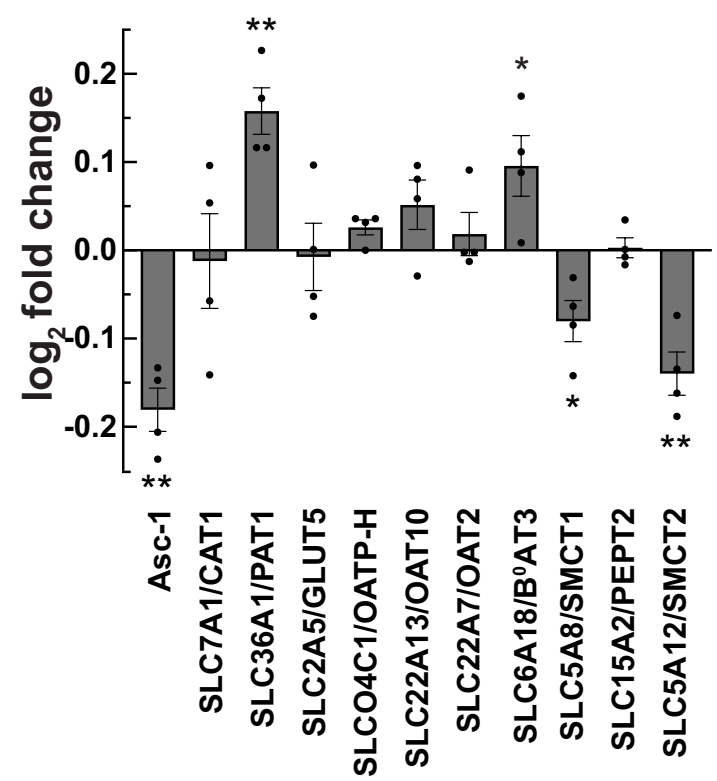

B

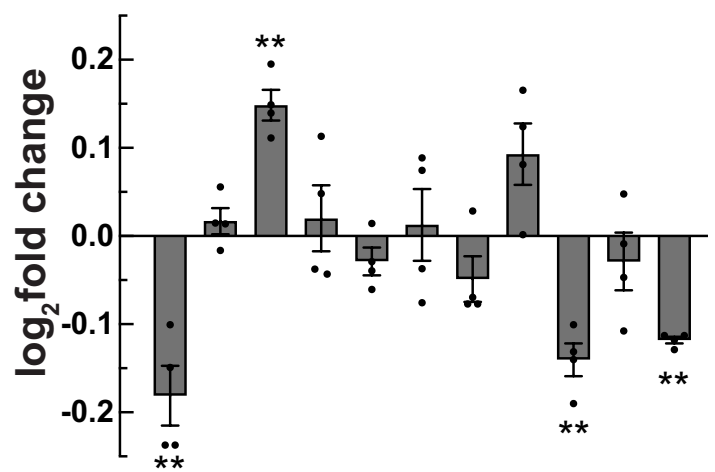

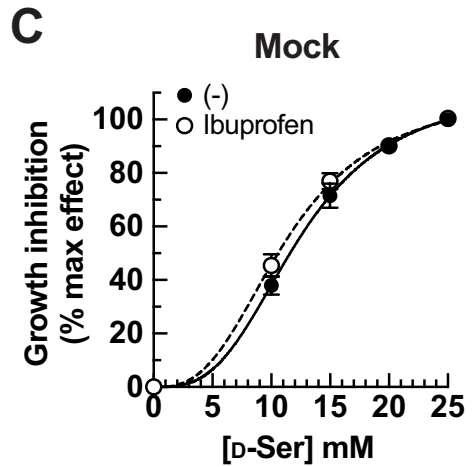

SMCT1

SMCT2
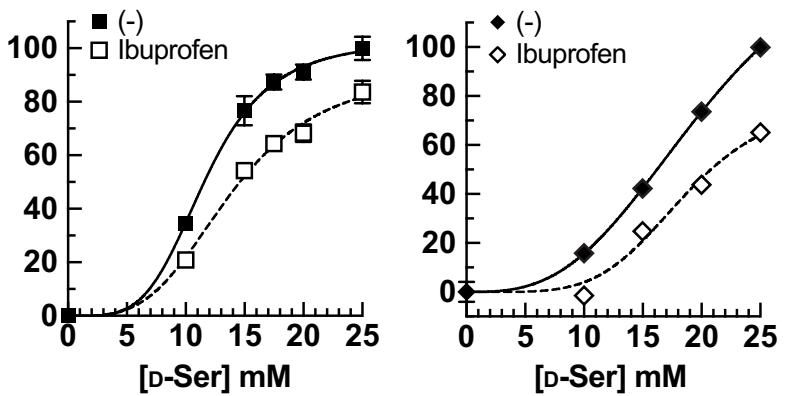
Figure 6: Wiriyasermkul, et al.

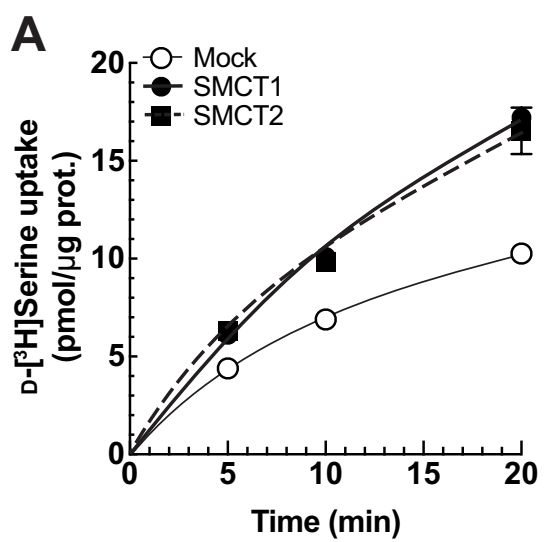

B

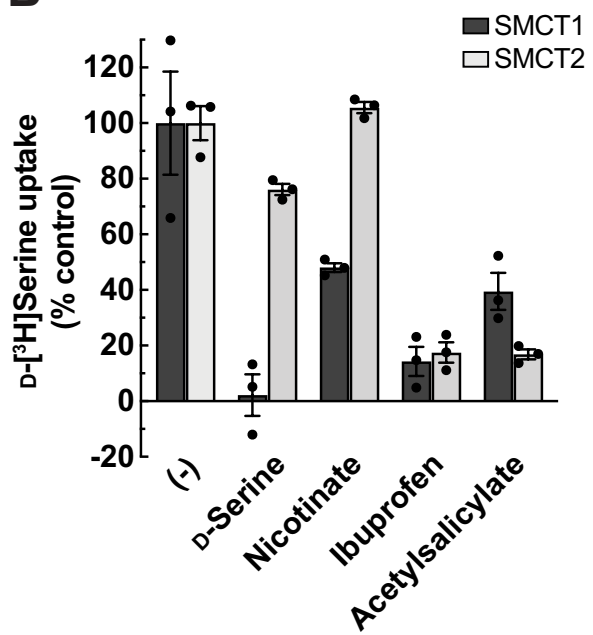

C

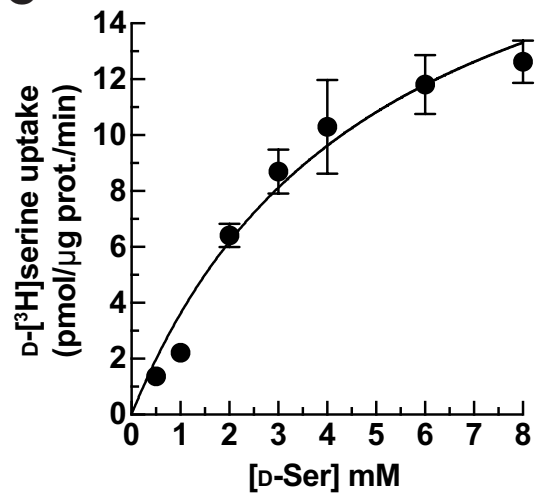


A

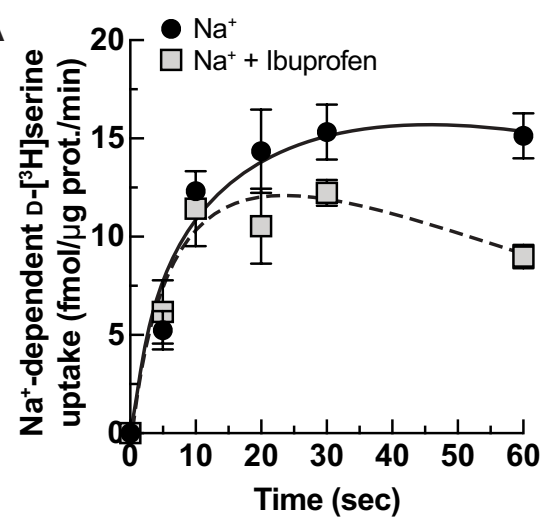

B

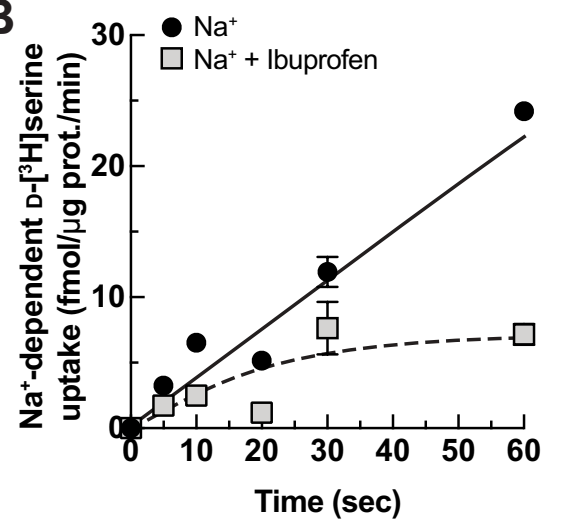

D

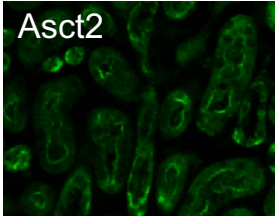

E
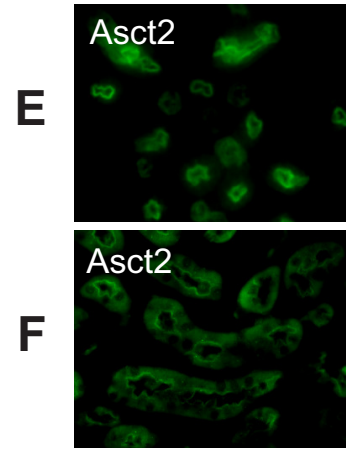

C
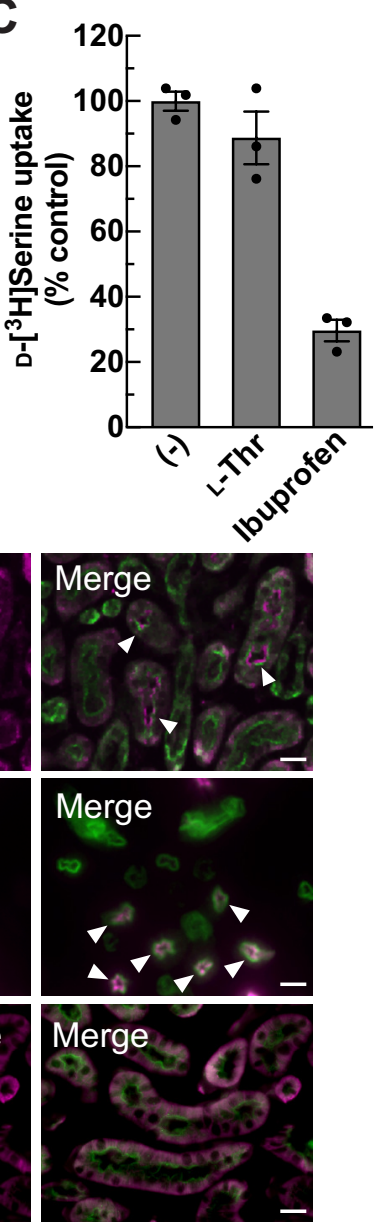
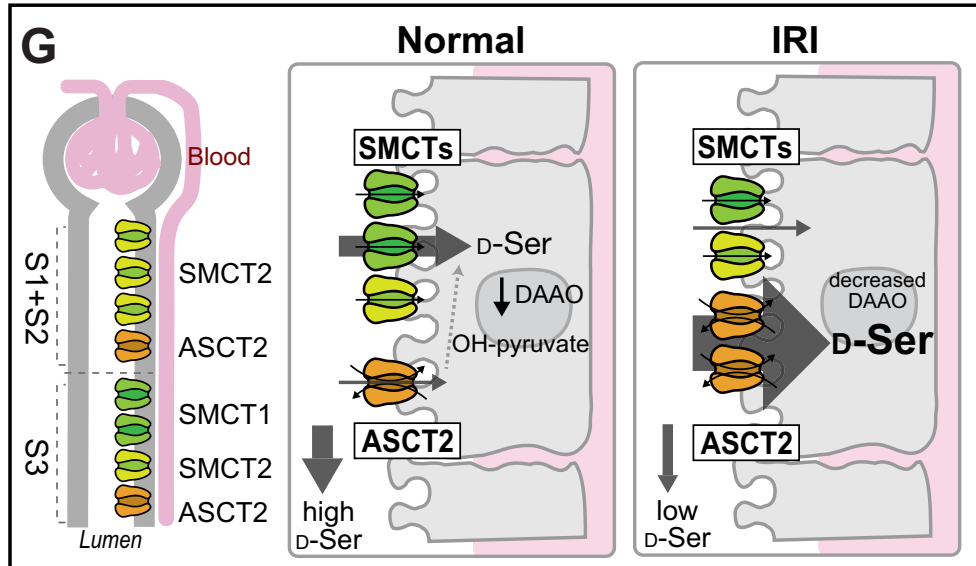
A

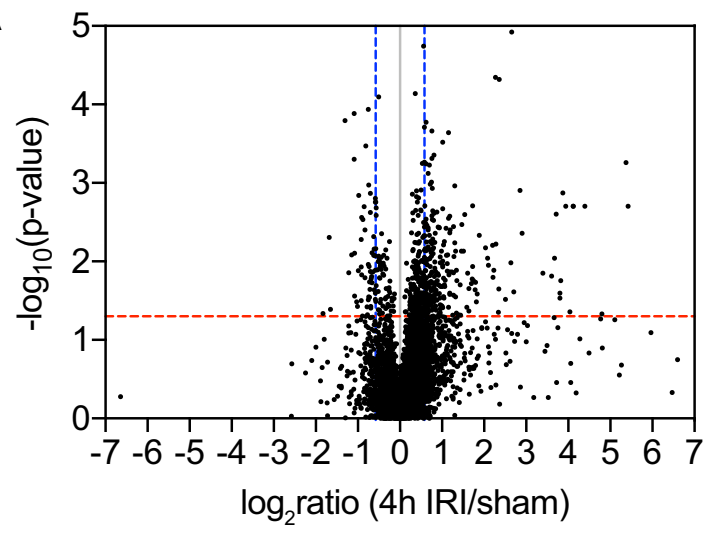

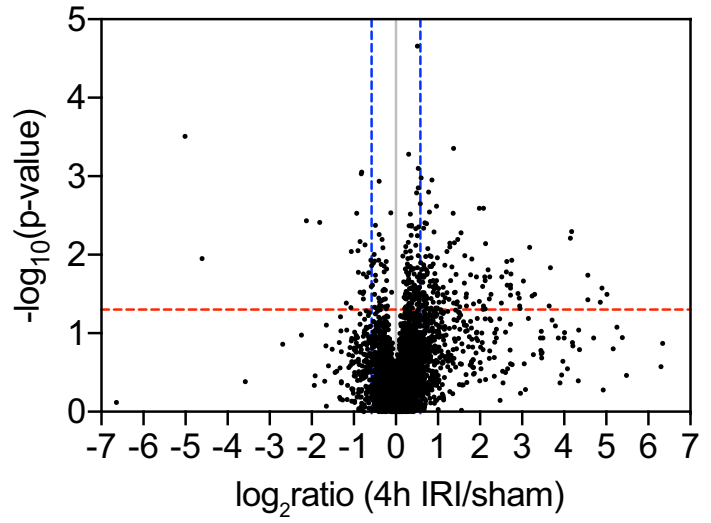

B
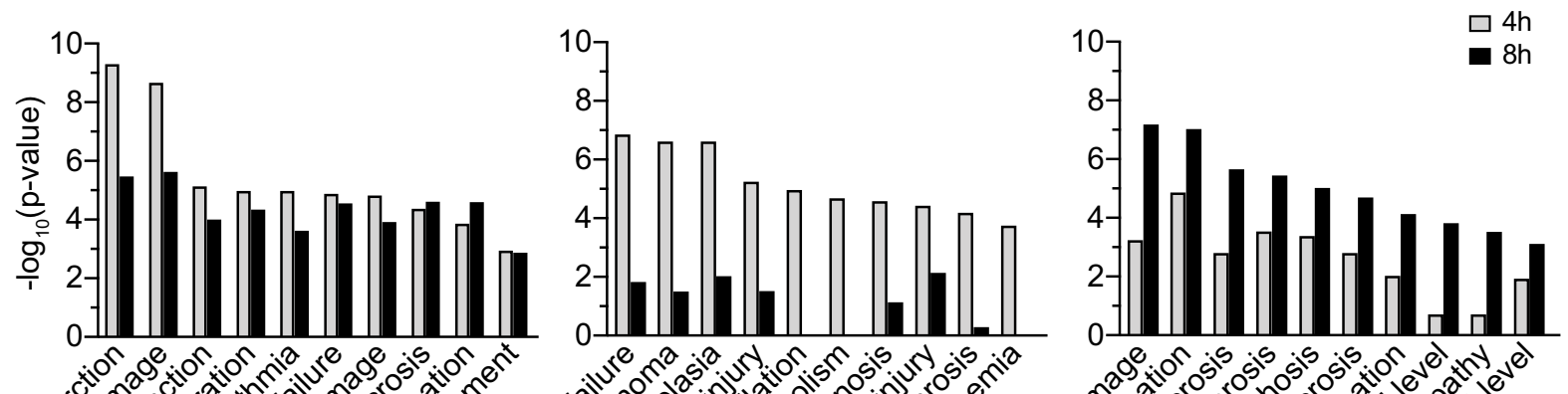
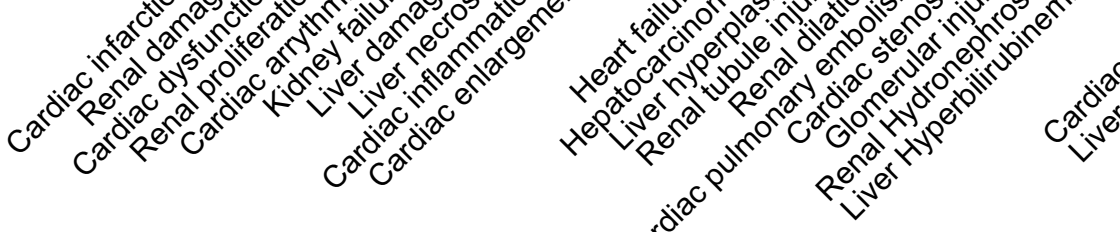

$0^{y^{2}} c^{y^{2}}$

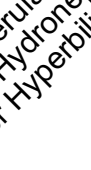

\section{C}
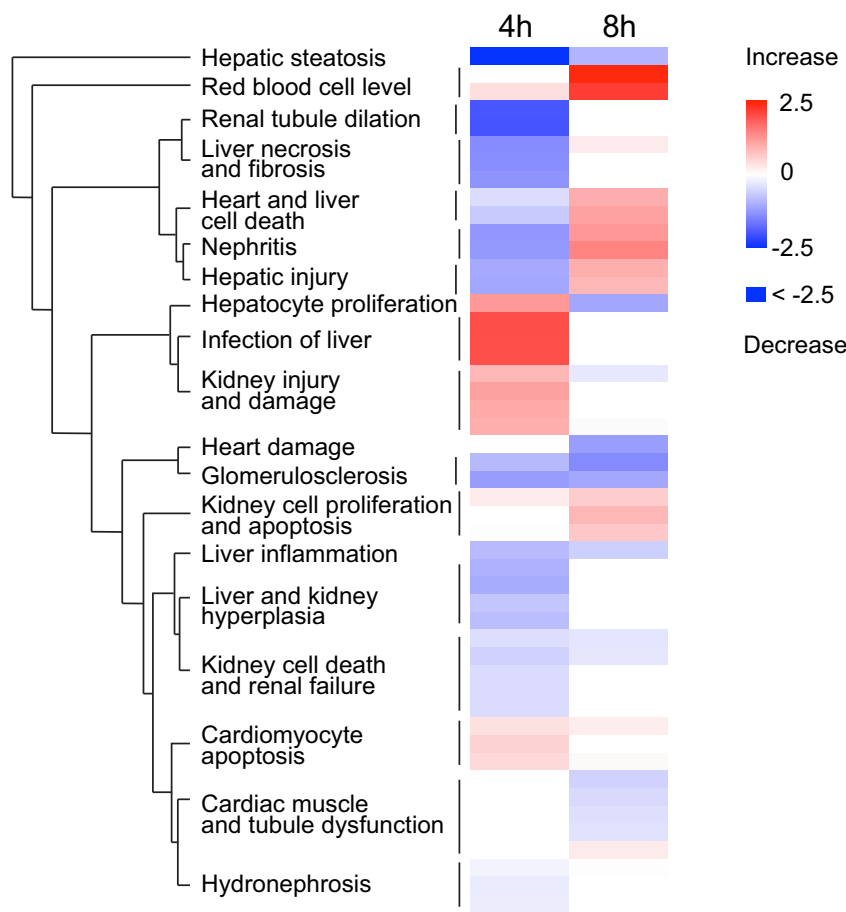

Decrease 
$A$
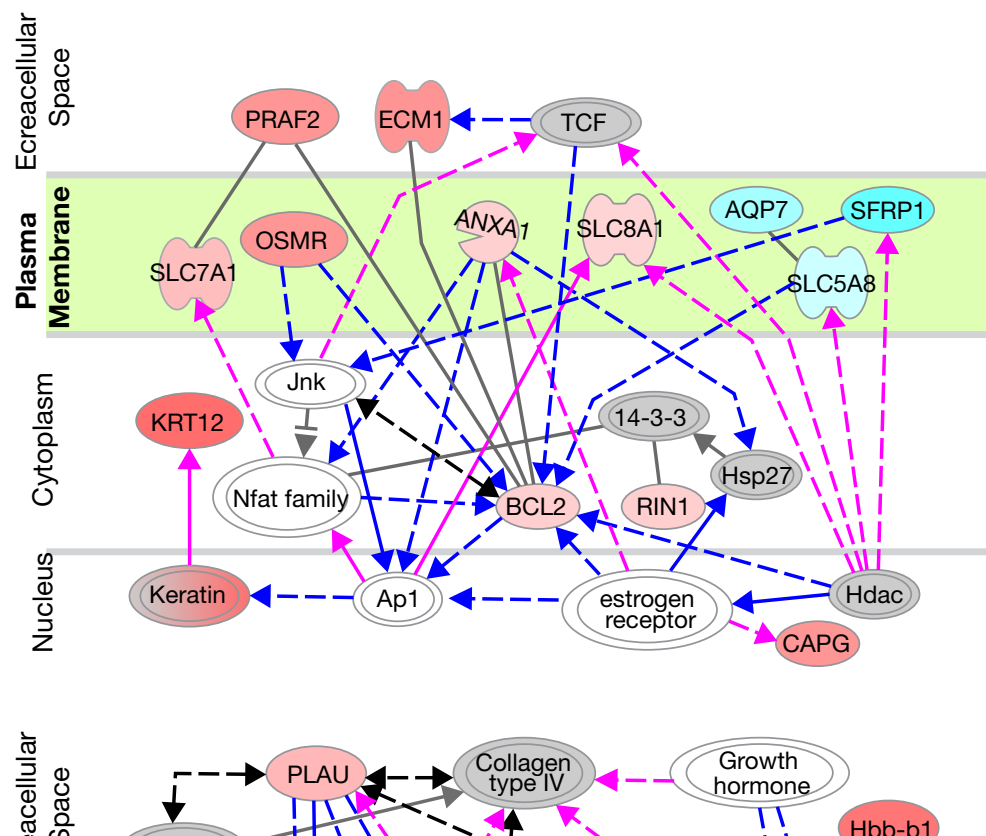

யั

疍

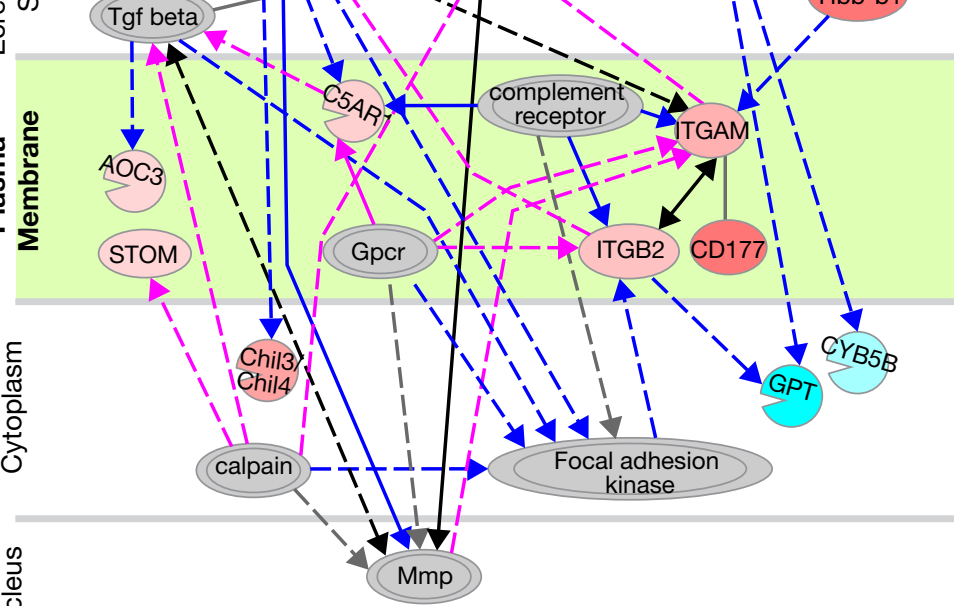

C

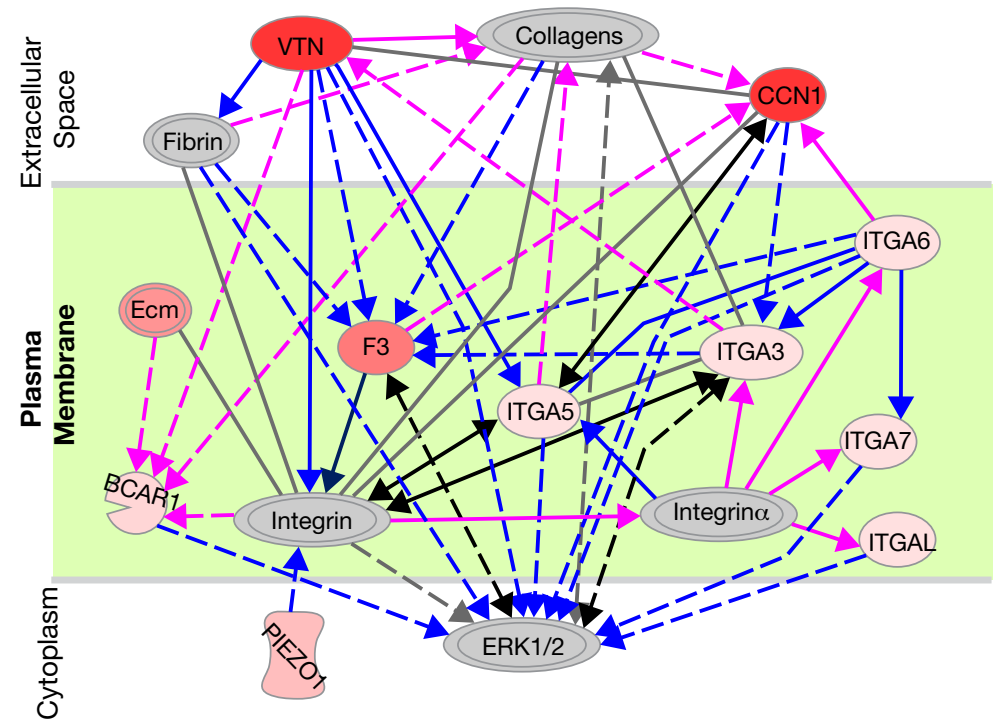




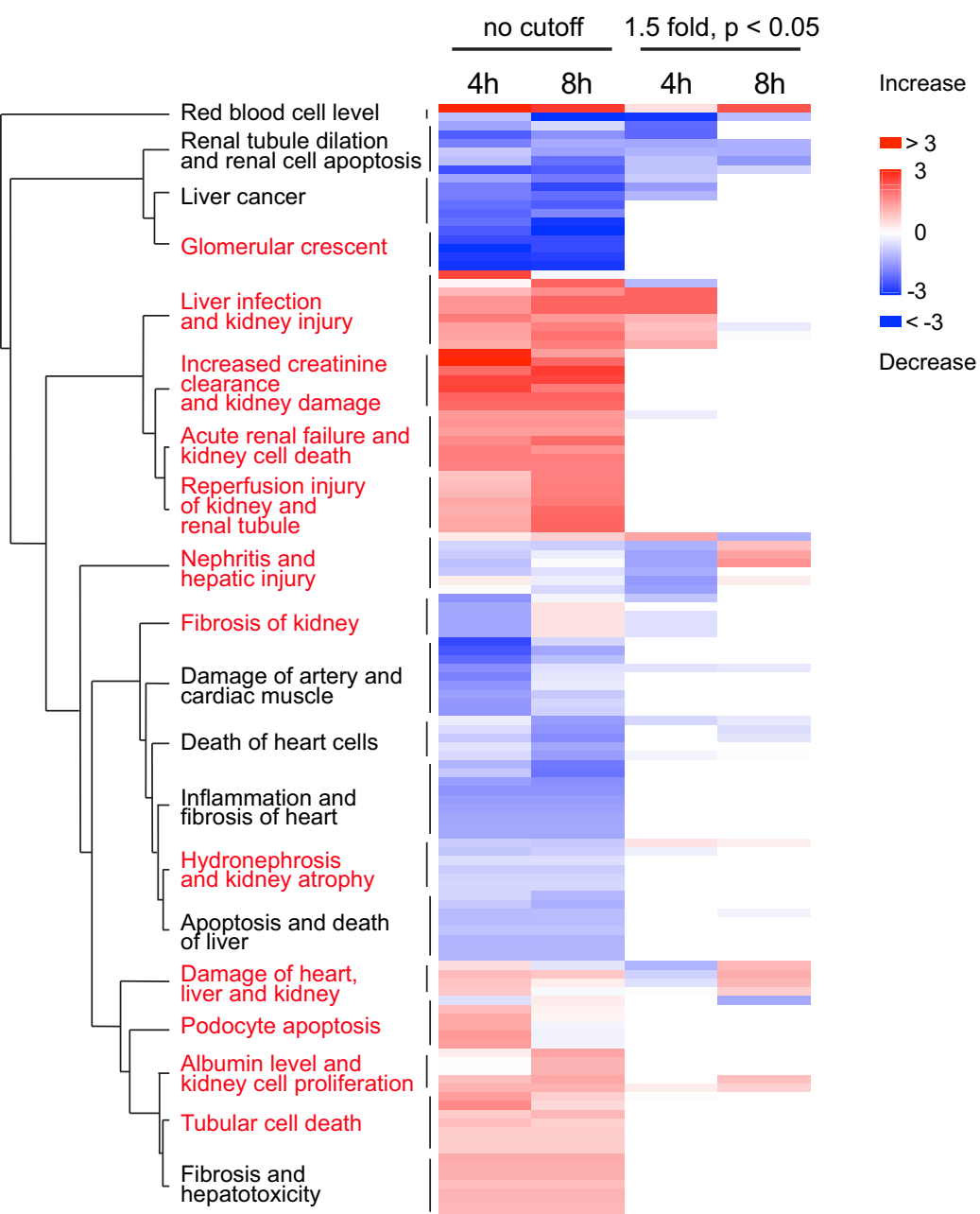



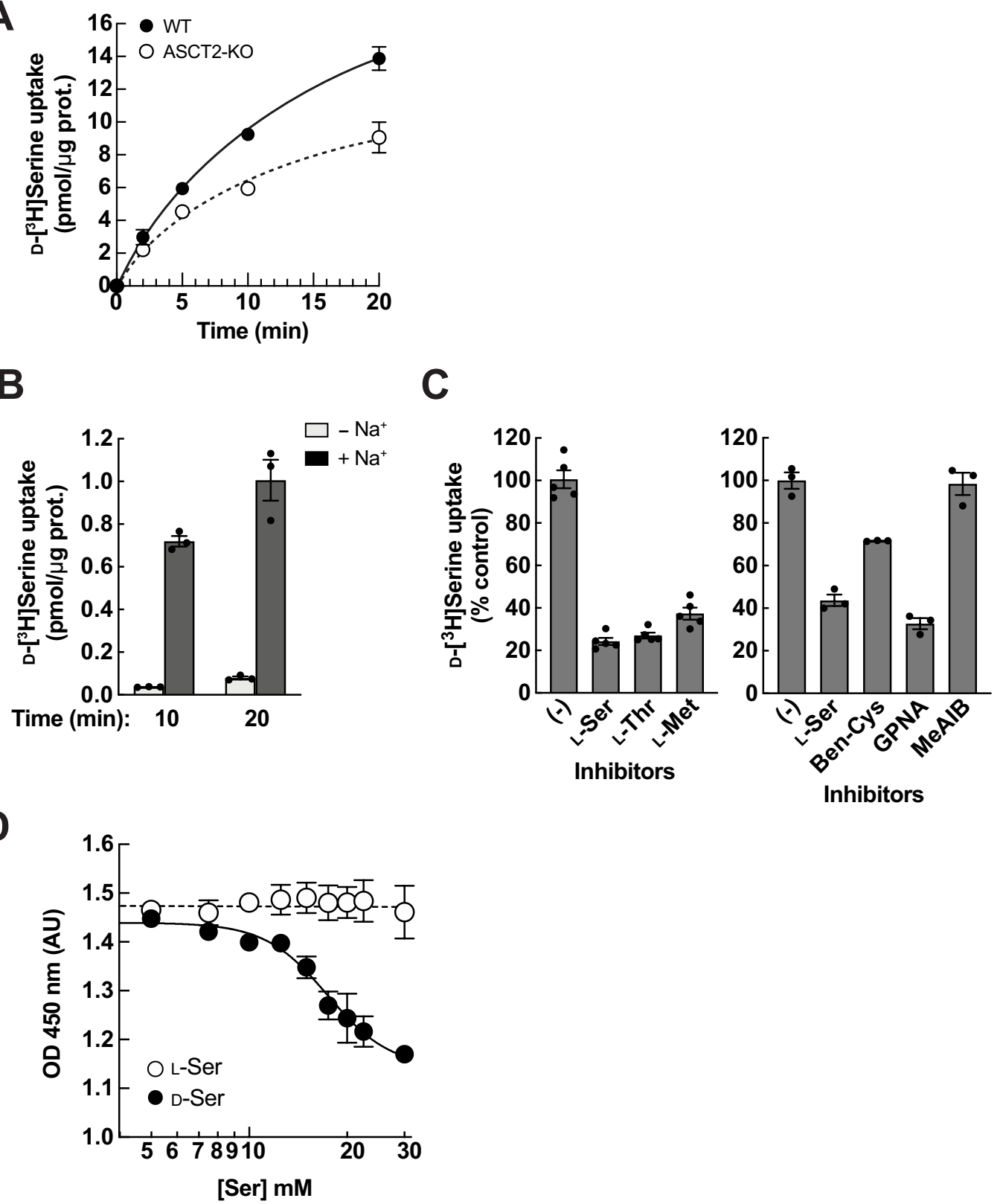
A
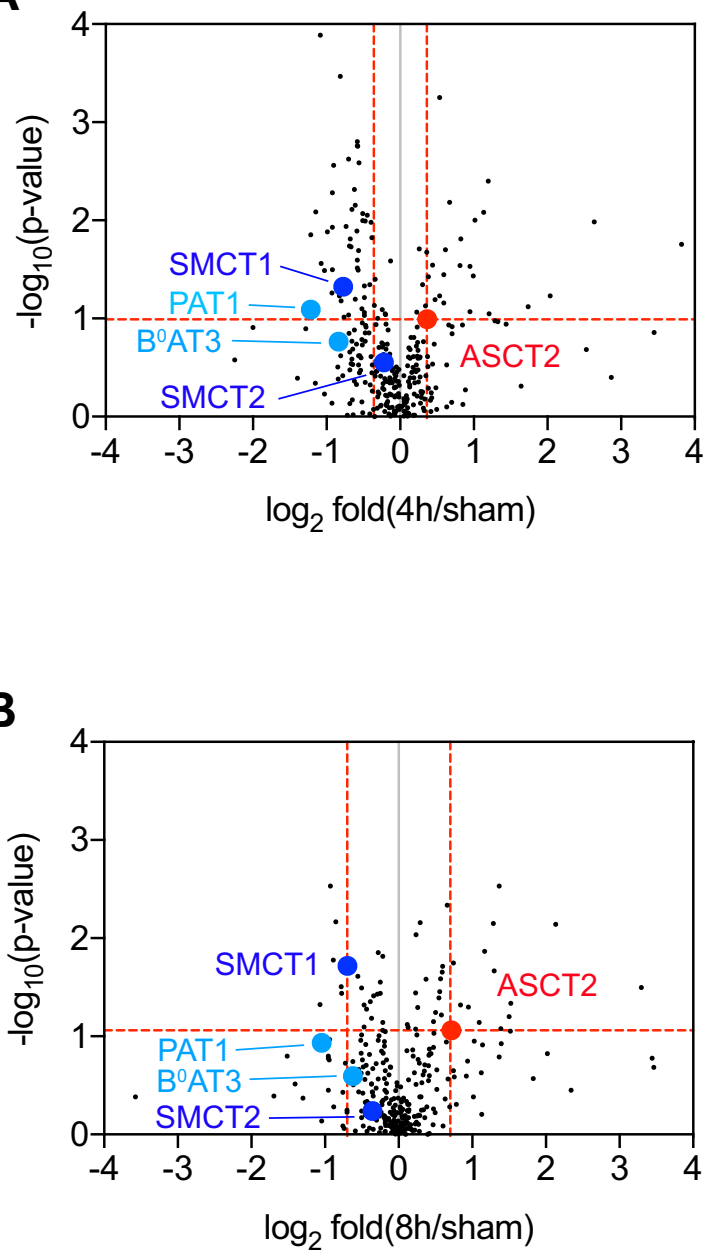
A

Clone: Mock SMCT1 SMCT2

ASCT2-siRNA: $\overline{-}+\overline{-}+\overline{-}$
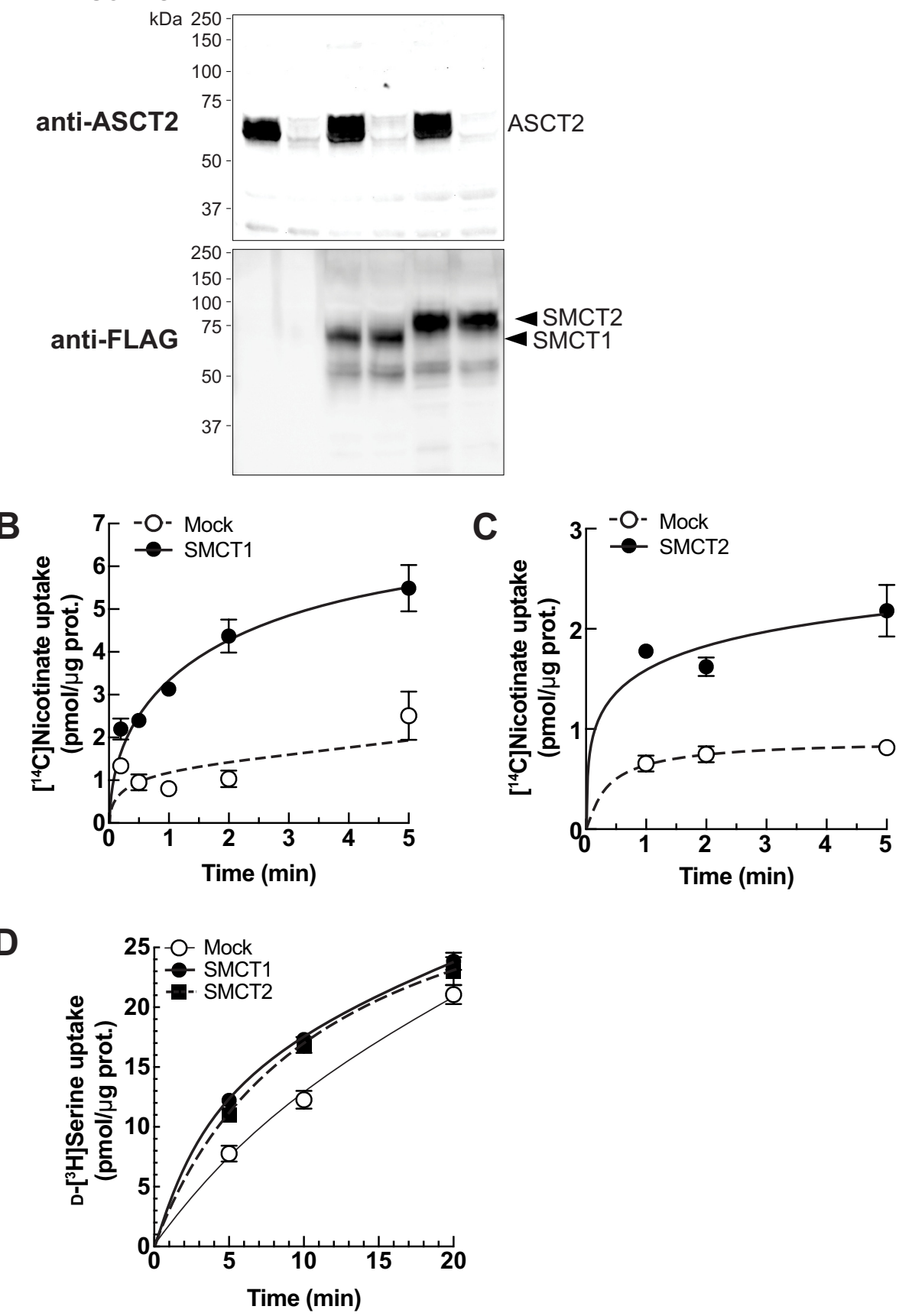

E

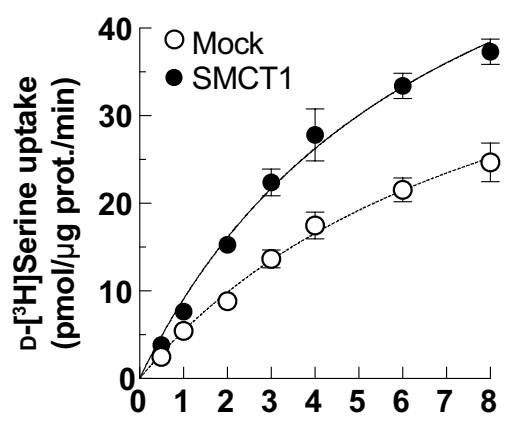

[D-Ser] mM 
A

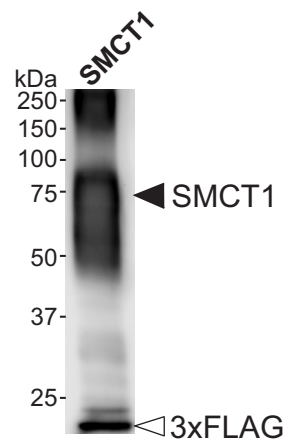

B

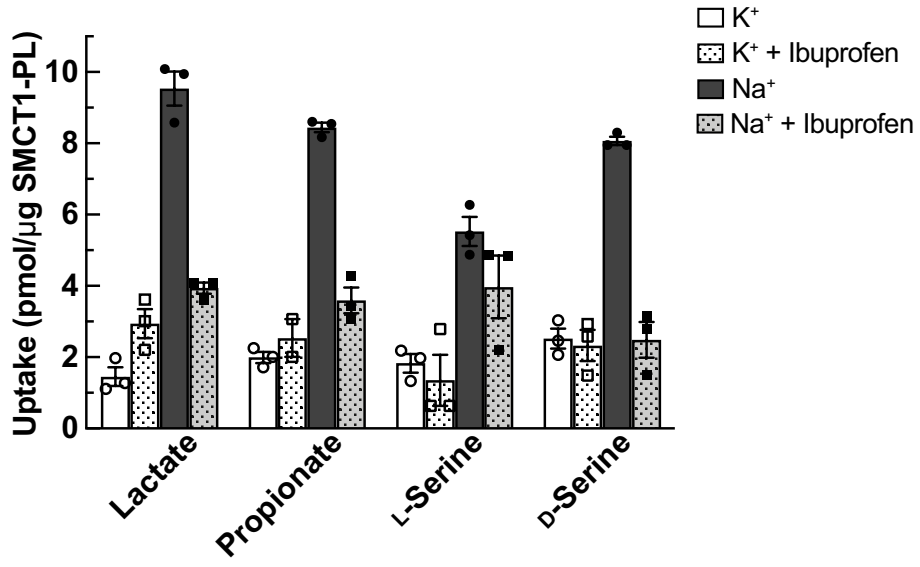

Radiolabeled substrates

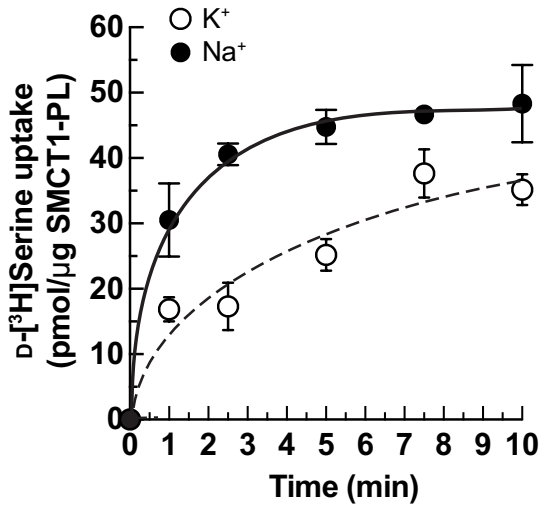


